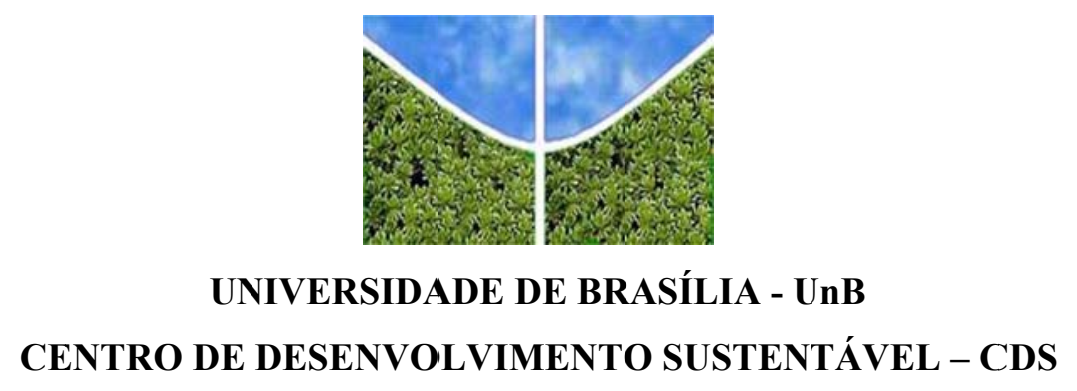

LÍVIA MIRANDA DE OLIVEIRA

PESQUISA-AÇÃO EM EDUCAÇÃO AMBIENTAL - EMPODERAMENTO DOCENTE PARA PRÁTICAS SUSTENTÁVEIS

ORIENTADOR: DR. CARLOS HIROO SAITO

Brasília, DF

Dezembro de 2016 
UNIVERSIDADE DE BRASÍLIA - UnB

CENTRO DE DESENVOLVIMENTO SUSTENTÁVEL - CDS

\title{
PESQUISA-AÇÃO EM EDUCAÇÃO AMBIENTAL - EMPODERAMENTO DOCENTE PARA PRÁTICAS SUSTENTÁVEIS
}

\author{
LÍVIA MIRANDA DE OLIVEIRA
}

ORIENTADOR: DR. CARLOS HIROO SAITO

DISSERTAÇÃO DE MESTRADO

Brasília, DF

Dezembro de 2016 


\section{PESQUISA-AÇÃO EM EDUCAÇÃO AMBIENTAL - EMPODERAMENTO DOCENTE PARA PRÁTICAS SUSTENTÁVEIS}

Dissertação de Mestrado submetida ao Centro de Desenvolvimento Sustentável da Universidade de Brasília, como parte dos requisitos necessários para a obtenção do Grau de Mestre em Desenvolvimento Sustentável, opção acadêmica.

Aprovado por:

Professor Dr. Carlos Hiroo Saito, (CDS/UnB)

(Membro interno vinculado ao programa - Orientador)

Professora Dra. Doris A. V. Sayago (CDS/UnB)

(Examinadora Interna vinculada ao programa)

Professora Dra. Érika Germanos (UniCEUB - Brasília, DF)

(Examinadora Externa não vinculada ao programa)

Brasília, DF, 23 de dezembro de 2016. 
OLIVEIRA, LÍVIA MIRANDA.

Pesquisa-ação em educação ambiental - empoderamento docente para práticas sustentáveis/ Lívia Miranda de Oliveira; orientador Dr. Carlos Hiroo Saito. Brasília, 2016.

126 p.; il.

Dissertação de Mestrado - Universidade de Brasília. Centro de Desenvolvimento

Sustentável.

1. Pesquisa-ação; 2. Educação ambiental; 3. Formação e empoderamento docente; 4. Práticas sustentáveis; 5. Combate à dengue; 6. Brasília.

I. UnB-CDS

É concedida à Universidade de Brasília permissão para reproduzir cópias desta dissertação e emprestar ou vender tais cópias para propósitos acadêmicos e científicos. A autora reserva outros direitos de publicação e nenhuma parte desta dissertação pode ser reproduzida sem a autorização por escrito da autora. 
"O rio representa a sociedade; a sua correnteza, o paradigma dominante; e o curso do rio, o processo histórico. Para mudarmos o rio (sociedade), precisamos interferir na correnteza (paradigmas) do seu curso (processo histórico). Como fazer se não quero ser carregado pela correnteza?"

(Guimarães, 2004, p. 30) 
Dedico este trabalho aos meus amados Daniel Gardino e

Gustavo Miranda Gardino.

O sentido da vida traz em seu bojo a família. 


\section{AGRADECIMENTOS}

Ao meu bondoso Deus. Único capaz de acompanhar-me em todos os momentos da vida, ofertando amor, proteção, paciência e equilíbrio para a árida incursão nos estudos, revelando que a hercúlea escalada me fortaleceu.

Aos tesouros que Deus me concedeu, Daniel e Gugu, agradeço a compreensão pelas ausências, a paciência com o estado de exaustão permanente, o apoio do esposo nas tabulações da dissertação.

Ao querido orientador Dr. Carlos Hiroo Saito, cuja práxis docente impactou, inspirou e transformou minha compreensão sobre o agir educativo à luz das questões socioambientais.

Aos meus pais, Mariano e Sofia pela educação e proteção.

Aos meus irmãos, sobrinhos, cunhados (as) e amigos que, embora presença física rarefeita, comungam da alegria de minha caminhada.

À direção, coordenação, corpo docente e funcionários do CDS. Por seu ambiente agradável, de riqueza epistêmica e acolhedora durante o estado gravídico o qual eu me encontrei em um período do mestrado.

Ao querido amigo Alex Sandro Araújo, em sua doação sem pormenores à pesquisa-ação educativa e preocupação outrora revelada com o meio ambiente e as pessoas.

Às queridas amigas da turma de mestrado, Tassila Kirsten e Daniesse Kasanoski. Pela troca de saberes, afeição e sorrisos. Se eu pudesse, pulverizaria o mundo com a simpatia e amizade de vocês.

Às queridas amigas oficineiras Cláudia Nascimento e Terezinha Lima. O acreditar de vocês no potencial deste trabalho reverberou constantemente.

À amiga Lucicléia Silva, pela troca de experiência, saberes e as referências compartilhadas.

Aos gestores, coordenadores e alunos dos oitavos anos do CEF 602 e CRE Recanto das Emas pelo apoio, envolvimento e acolhimento da pesquisa.

Aos docentes de nossa nação que, mesmo ocultos em suas ações praticadas, ajudam na construção das gerações. 


\section{RESUMO}

A crise civilizatória contemporânea que envolve o modo de vida humana e o meio ambiente deve ser estudada e enfrentada nos diversos ambientes da sociedade, sendo a escola campo importante para esse enfrentamento. Considerando que a parte mais densa das atividades desenvolvidas no ambiente escolar advém das interações entre docentes e discentes, a formação dos professores torna-se objeto fundamental para investigação, uma vez que esta influencia diretamente nas atividades desenvolvidas ao longo do processo educacional. Diante deste cenário, o presente trabalho objetivou analisar a potencialidade da pesquisa-ação na educação ambiental para o empoderamento docente na busca de práticas educativas sustentáveis. Para tanto foi constituída uma comunidade investigativa, composta por um professor da educação básica e a pesquisadora, e realizada nos meses de maio a setembro de 2016 pesquisa-ação em educação ambiental em uma escola pública do Distrito Federal que envolveu a temática combate à dengue. As atividades desenvolvidas percorreram os momentos de planejamento, ação/observação e reflexão da espiral cíclica da pesquisa-ação à luz da educação ambiental, visando o empoderamento docente para a adoção de atitudes mais sustentáveis. Dentre os resultados obtidos, verificou-se um refinamento do olhar docente para questões socioambientais, conduta e visão mais acessíveis, dialógicas e investigativas além do empoderamento docente por meio da adoção teóricometodológica da pesquisa-ação educativa, o que viabilizou a adoção de sustentabilidade nas ações refletidas e planejadas.

Palavras-chave: pesquisa-ação; educação ambiental; formação e empoderamento docente; práticas sustentáveis; combate à dengue; Brasília. 


\begin{abstract}
The contemporary civilization crisis that involves the human way of life and the environment must be studied and faced in the different environments of society, and school is an important field for this confrontation. Considering that the denser part of the activities developed in the school environment comes from the interactions between teachers and students, teacher training becomes a fundamental object for research, since it directly influences the activities developed throughout the educational process. Given this scenario, the present work aimed to analyze the potential of action research in environmental education for teacher empowerment in the search for sustainable educational practices. For that, a research community was formed, composed of a teacher of basic education and the researcher, and carried out in the months of May to September of 2016 action research in environmental education in a public school of the Federal District that involved the combat of dengue. The activities carried out covered the moments of planning, action/observation and reflection of the cyclical spiral of action research in the light of environmental education, aiming at teacher empowerment to adopt more sustainable attitudes. Among the results obtained, there was a refinement of the teaching approach to social-environmental issues, more accessible conduct, and vision, dialogic and investigative, besides teacher empowerment through the theoreticalmethodological adoption of educational research-action, which made the adoption of sustainability viable actions reflected and planned.
\end{abstract}

Keywords: action research; environmental education; teacher training and empowerment; sustainable practices; against dengue; Brasilia. 


\section{LISTA DE FIGURAS}

FIGURA 1 - Espiral Lewiniana da pesquisa-ação

FIGURA 2 - Tendências da pesquisa-ação.

FIGURA 3 - Os momentos da pesquisa-ação.

FIGURA 4 A 6 - Saída de Campo

FIGURA 7 - Cartaz de campanha publicitária do Ministério da Saúde.

FIGURA 8 - Nuvem de palavras da décima questão do questionário diagnóstico.

FIGURA 9 - Cartaz de campanha publicitária da Secretaria Estado de Saúde do Governo do Distrito federal.

FIGURA 10 - Palestra e stand realizados pela DIVAL/SESDF.

FIGURA 11 - Mapa das áreas onde a dengue foi registrada.

FIGURA 12 - exploração do mapa da cidade pelos alunos.

FIGURA 13 - Representação dos cuidados que podem ser tomados pelos doentes durante a fase infectiva.

FIGURA 14 - Lixo nos arredores da escola.

FIGURA 15 - Conflito socioambiental denunciado pelos alunos.

FIGURA 16 - Preparativos dos materiais para a feira de ciências local.

FIGURA 17 - Alunos expondo o projeto na feira de ciências local.

FIGURA 18 - Folder ilustrativo das premissas do projeto.

FIGURA 19 - Banner do projeto exposto no Circuito de Ciências Regional

FIGURA 20 - Planejamento décimo ciclo

FIGURA 21 - Imagens provocadoras do Lixão da Estrutural para a reflexão a respeito da existência de lixões.

FIGURA 22 - Convergência dos setores consultados sobre o conflito socioambiental.

FIGURA 23 - Mutirão socioambiental e certificação dos alunos e servidor participantes.

FIGURA 24 - Nuvem de palavras resultante da união dos quatro registros autoreflexivos.

FIGURA 25 - Compilação das dez espirais cíclicas do estudo de caso. 


\section{LISTA DE TABELAS}

TABELA 1 - Aumento de casos notificados e prováveis de dengue no Brasil.

TABELA 2 - Frequência das justificativas ocorridas para a categoria "O mosquito não pode nascer".

TABELA 3 - Frequência das formas de prevenção segundo os discentes.

TABELA 4 - Sugestões dos alunos para resolução do conflito socioambiental do CEF 602 do Recanto das Emas.

TABELA 5 - Sugestões dos alunos para evitar a reincidência de conflitos análogos. 


\section{LISTA DE QUADROS}

QUADRO 1 - Diretrizes, princípios, recomendações sobre a EA na formação continuada, segundo vários eventos internacionais e a Política Nacional de Educação Ambiental.

QUADRO 2 - Problemáticas relacionadas à educação ambiental e as vertentes do DS no Brasil.

QUADRO 3 - Cronograma das atividades desenvolvidas no projeto.

QUADRO 4 - convergências entre alunos direção e CRE sobre resolução do conflito socioambiental.

QUADRO 5 - questões norteadoras dos registros auto-reflexivos. 


\section{LISTA DE SIGLAS}
ABRASCO - Associação Brasileira de Saúde Coletiva
CDS - Centro de Desenvolvimento Sustentável
CED - Centro Educacional
CEF - Centro de Ensino Fundamental

CGPNCD - Coordenação Geral do Programa Nacional de Controle da Dengue

CI - Comunidade Investigativa

CNEA - Conferência Nacional de Educação Ambiental

Conass - Conselho Nacional de Secretários de Saúde

Conasems - Conselho Nacional de Secretarias Municipais de Saúde

CONSEA - Conselho Nacional de Segurança Alimentar e Nutricional

CRE - Coordenação Regional de Ensino

DF - Distrito Federal

DIVAL - Diretoria de Vigilância Ambiental

DS - Desenvolvimento Sustentável

EA - Educação Ambiental

EAL - Educação Ambiental Lúdica

EAPE - Escola de Aperfeiçoamento dos Profissionais da Educação

EDS - Educação para o Desenvolvimento Sustentável

Fiocruz - Fundação Oswaldo Cruz

GDF - Governo do Distrito Federal

LDB - Lei de Diretrizes e Bases da Educação Nacional

MCTI - Ministério da ciência, tecnologia, inovações e comunicação.

MS - Ministério da Saúde

NTE - Núcleo de Tecnologia

OMS - Organização Mundial da Saúde

OP - Oficina Pedagógica

PA - Pesquisa-ação

PEVRE - Parque Ecológico e Vivencial do Recanto das Emas

PL - Projeto de Lei

PNEA - política Nacional de Educação Ambiental

PPP - Projeto Político Pedagógico 
RA - Região Administrativa

SEDF - Secretaria de Estado de Educação do Distrito Federal

SES - Secretaria de Estado de Saúde

SESI - Serviço Social da Indústria

UNIAG - Unidade de Administração Geral 


\section{SUMÁRIO}

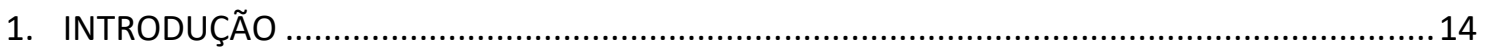

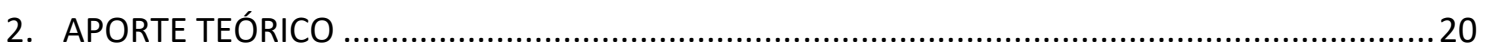

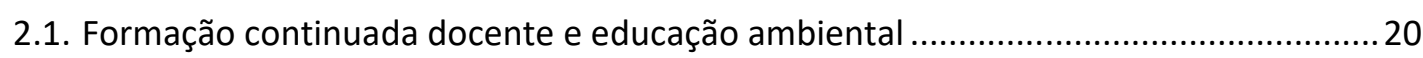

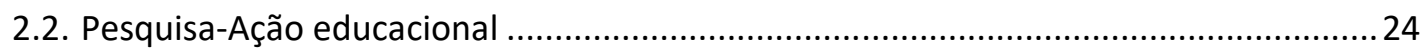

2.3. O percurso da pesquisa-ação conduz ao empoderamento docente. ............................33

2.4. Do desenvolvimento sustentável para práticas educativas sustentáveis: travessias...34

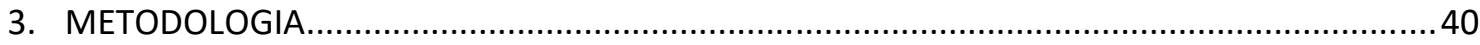

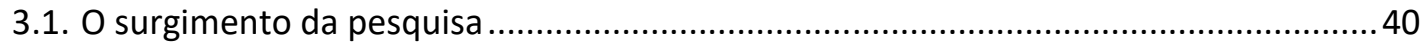

3.2. O território, os atores e a pesquisa-ação desenvolvida. ..............................................43

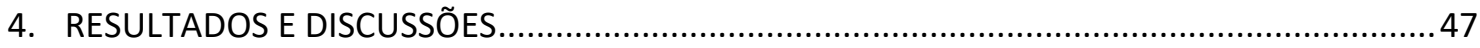

4.1.1. Primeiro ciclo - Questionário diagnóstico. ............................................................ 47

4.1.2. Segundo ciclo - Palestra sobre combate à dengue. .............................................57

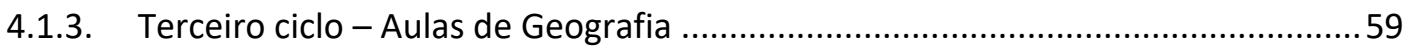

4.1.4. Quarto ciclo - Aulas interdisciplinares de Geografia e Ciências.............................64

4.1.5. Quinto ciclo - Preparativos para a Feira de Ciências Local. ..................................73

4.1.6. Sexto ciclo: Feira de ciências etapa local.............................................................76

4.1.7. Sétimo ciclo - Questionário Avaliativo do Projeto. ...............................................77

4.1.8. Oitavo ciclo - Estudos e planejamentos: luzes para o encerramento do projeto. 78

4.1.9. Nono ciclo - Circuito Regional de Ciências ............................................................87

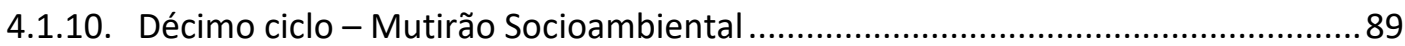

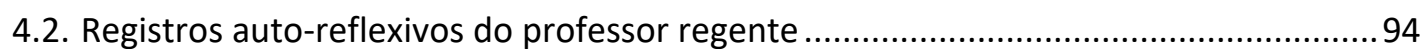

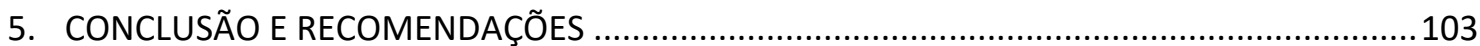

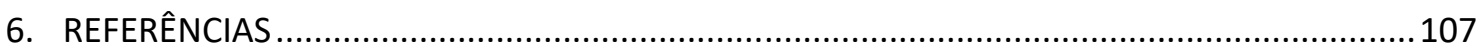

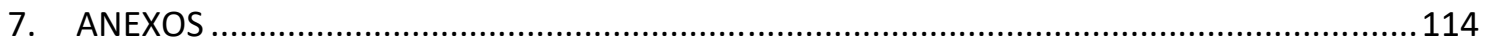


INTRODUÇÃO

O desenvolvimento da educação ambiental (EA) na esfera formal de ensino necessita de capacitação permanente e conhecimentos docentes específicos das múltiplas disciplinas de forma individual e integrada (multidisciplinar e interdisciplinar), além de um olhar crítico das situações para a sua execução.

Para tanto, não existem garantias de que a profissionalização dos professores que atuam na educação básica seja capaz de contrapor a situação gerada pelo adensamento populacional que conduziu a contemporaneidade à problemática ambiental (dentre outros da poluição do meio, colapso de recursos naturais, energéticos e de alimentos), gerando uma crise de civilização (Leff, 2010, p. 43).

O problema apresentado decorre do paradigma cartesiano herdado das sociedades pretéritas, segundo o qual para conhecer o todo era preciso fragmentá-lo (Descartes, 1996, p. 122). Este modelo privilegia a compreensão científica isolada dos objetos da ciência em geral e dos componentes do meio ambiente, suscitando lacunas nos estudos e em parte dos conhecimentos a que se chegou.

A especialização dos saberes científicos fragmentados incorporou ao longo da história uma tendência de integrar produção científica aos processos produtivos econômicos (Leff, 2010, p. 32), desvinculando o pensar articulado, sistêmico e interdisciplinar às compreensões do meio.

O legado cartesiano contribuiu para o presente caracterizado pela existência de uma gama de professores com formação disciplinar tendo que atuar interdisciplinarmente, uma vez que o que se busca é um modo de vida cada vez mais sustentável, capaz de equilibrar a forma de vida humana e meio ambiente.

$\mathrm{Na}$ defesa de que a compreensão crítica sobre desenvolvimento sustentável ${ }^{1}$ (DS) é de extrema importância para a sua incorporação nas práticas dos profissionais de

\footnotetext{
${ }^{1}$ Mais do que conhecer o conceitos de DS apresentado pelo relatório Brundtland, é importante associar conhecimentos sobre sua trajetória, contextualizando com fatores políticos, históricos, culturais, epistemológicos e econômicos. Buscando refletir sobre os distanciamentos entre discurso e prática, para evitar a armadilha dos chamados "caronas do discurso" (Fonseca e Bursztyn, 2007, p. 23).
} 
educação, como um caminho de base para a hercúlea, se não utópica ${ }^{2}$, tarefa de transição para uma sociedade sustentável, defende-se a necessidade de desenvolver ações no âmbito da formação de professores para essa transição.

Ao compreender que a Educação Ambiental abrange o Desenvolvimento Sustentável (DS), atividades desenvolvidas pela educação ambiental em espaços de formação continuada aos profissionais da educação tem potencial de incorporar sustentabilidade à práxis docente. A proximidade entre EA e DS levou autores a defenderem a substituição do termo Educação Ambiental pelo termo Educação para o Desenvolvimento Sustentável (EDS).

Marcinkowski (2010) comentou os desafios e interfaces entre o DS e a EA não resumindo um em outro, mas enfatizando que para o benefício da EA e EDS, ambas devem expandir e refinar suas compreensões da literatura ambiental, ademais os programas de EA devem fortalecer e ampliar a mudança de comportamento para a participação cidadã em comunidades de base e a resolução de problemas de larga escala.

A esse respeito, adota-se o pensamento de Saito (2013) que defende a manutenção do termo Educação Ambiental, uma vez que esta não se limita somente à alfabetização ecológica, mas tem relevante abrangência social e interdisciplinar.

A forma e alcance desta atuação são levantados na atual pesquisa ao considerar que a EA e o DS esbarram na deficiência de sua compreensão e aplicação. Embora tenha iniciado o reconhecimento político da EA, há pouco consenso sobre sua compreensão, natureza ou princípio (Saito, 2012, p. 55).

Alguns autores como Leff (2010), Flickinger (1994) e Grün (1996) consideram necessária uma abordagem hermenêutica ${ }^{3}$ como saída possível para ampliar a compreensão da realidade e resolver situações conflitantes necessárias à EA. Porém, carece na literatura o aprofundamento em metodologias adequadas que alcançariam tal abordagem (Pedrini e Saito, 2014, p. 34).

\footnotetext{
${ }^{2}$ Bursztyn e Bursztyn (2012) compreendem o desenvolvimento sustentável como a utopia para o século XXI em relação às chamadas utopias do séc. XX, como o socialismo, consumismo, welfare state, desenvolvimentismo.

${ }^{3}$ Considera-se o conceito filosófico de hermenêutica em suas abordagens epistemológicas e ontológicas. A primeira seria a compreensão e interpretação total de registros escritos e a segunda, um esforço de compreender a realidade em sua totalidade.
} 
Sobrepujar a lacuna da compreensão e incorporar a EA nas práticas docentes para um modo de vida mais sustentável, pode iniciar-se tomando apoio no texto da Lei n 9.795 de 27 abril de 1999 que instituiu a Política Nacional de Educação Ambiental (PNEA), onde pretendeu-se fortalecer o pensar e o agir nas relações entre humanos e meio ambiente.

A PNEA trouxe luz às ações brasileiras em EA por meio da instituição de princípios, objetivos e o seu conceito como sendo:

os processos por meio dos quais o indivíduo e a coletividade constroem valores sociais, conhecimentos, habilidades, atitudes e competências voltadas para a conservação do meio ambiente, bem de uso comum do povo, essencial à sadia qualidade de vida e sua sustentabilidade (Lei 9.795/99, Art. $1^{\circ}$ ).

A abrangência inter, multi e até transdisciplinar da EA não torna sua definição algo fácil, no entanto o conceito definido na PNEA é fruto de uma trajetória que o construiu e reconstruiu, ao longo dos variados congressos e conferências que abordaram a temática (Belgrado 1975, Tibilisi 1977, Moscou 1987, Toronto 1992, Rio-92, Tessalônia 1997), fator pelo qual a presente pesquisa adota o conceito de EA definido pela PNEA.

Sorrentino (2005), afirma que a política de EA desenvolvida no Brasil é uma estratégia para superar o paradigma da racionalidade instrumental que operou, no Brasil e no mundo, silenciamentos opostos à participação, à emancipação, à diversidade e à solidariedade.

Dentre as variadas e relevantes práticas em EA, a "capacitação voltada para os educadores de todos os níveis e modalidades de ensino" (BRASIL, 1999, p. 3), ou seja, a formação continuada será objeto de análise neste estudo, em compromisso com os princípios, objetivos e recomendações da PNEA, em tempos em que inúmeras ações dirigidas à EA são observadas, porém sem o aprofundamento crítico necessário.

A referência dada ao aprofundamento critico necessário deu-se pela observação de alguns autores com relação ao excesso de ativismo fortemente presenciado nas variadas atividades que envolvem EA (Sato, 2001, p. 22; Saito, 2012, p.62), em um excesso de práticas educativas "verdes", que não avançam na incorporação dos princípios e objetivos da EA segundo os documentos norteadores. Para Sato (2001) é 
necessário uma análise mais crítica, extraindo os momentos fecundos e compreendendo as tensões presentes em suas práticas e discursos.

A EA realizada com aprofundamento crítico permite aos atores envolvidos avançar em seu autoconhecimento e do contexto social o qual eles se inserem, o que conduz à transformação da realidade. Seu percurso revela os elementos que interferem no melhoramento das condições educacionais, sociais e ambientais.

Desta forma, a presente pesquisa busca responder: i) de que maneira a pesquisaação em educação ambiental pode contribuir para o empoderamento docente na busca de práticas sustentáveis; ii) é possível superar a mera constatação de problemas/entraves no ambiente educacional das escolas públicas no DF para incorporar a pesquisa-ação em EA por meio da formação continuada?

O alcance do objetivo geral da pesquisa, que consiste em delinear um procedimento educacional pautado no par restrospectivo-prospectivo, por isso críticoemancipatório, em pesquisa-ação na EA por meio da formação de professores que possa contribuir para o empoderamento docente na busca de práticas que levem os alunos a atitudes mais sustentáveis, perpassa o seguintes objetivos específicos:

a) Descrever e refletir sobre a abordagem da pesquisa-ação na educação ambiental.

b) Diagnosticar os principais obstáculos que impedem a realização de educação ambiental nos espaços educativos em que os professores envolvidos atuam.

c) Realizar um diagnóstico sobre as ações e concepções que envolvem a EA e sustentabilidade no público envolvido.

d) Elencar situações conflitantes na comunidade de atuação dos participantes para a promoção de ações seguindo a espiral cíclica da pesquisa-ação.

Para tanto, a adoção de uma teoria e metodologia que considere a multidisciplinaridade e complexidade da EA, foi fundamental para a realização do estudo, o que conduziu ao desenvolvimento de uma pesquisa-ação educacional. Paralelamente à PA foi registrado o potencial dessa adoção, teórico-metodológica, na promoção do empoderamento docente para a incorporação de práticas sustentáveis.

O lócus da pesquisa foi o Centro de Ensino Fundamental 602 do Recanto das Emas (CEF 602), uma escola pública do Distrito Federal, onde foi realizada pesquisaação educacional por uma comunidade investigativa, composta por um professor da escola que ministra a disciplina de geografia e "o pesquisador, atuando este como um amigo crítico" (Carr e Kemmis, 1986, aspas do autor). 
A PA desenvolvida no CEF 602 do Recanto das Emas envolveu a temática combate à dengue, realizando-se dez ciclos que juntos formaram uma espiral cíclica de pesquisa-ação, seguindo uma organização heurística dividida em: planejamento, ação, observação e reflexão (Carr e Kemmis, 1986, p. 186).

Os dados obtidos somaram registros auto-reflexivos do professor componente da comunidade investigativa, planejamentos dos ciclos, registros escritos e fotográficos das variadas atividades, documentos e ofícios. Falas significativas ${ }^{4}$ também foram consideradas para a análise de dados que, seguiu o modelo da análise de conteúdo de Bardin (2011).

Desta forma, a presente dissertação está estruturada em quatro partes:

1. A primeira referente ao aporte teórico da pesquisa abordou os conceitos e referências teórico-metodológicas adotadas na pesquisa cujos principais marcos foram a formação continuada docente e educação ambiental, a pesquisa-ação educativa e o empoderamento.

2. A metodologia que utilizou da análise de conteúdo de Bardin (2011) para o tratamento dos dados obtidos além da caracterização da área de ocorrência e os atores envolvidos na pesquisa.

3. Na penúltima parte, a dissertação expõe os resultados dos dados obtidos pela espiral cíclica da pesquisa-ação em educação ambiental realizada, adquiridos por meio de questionários, observação participante, falas significativas, reflexões coletivas/individuais e registros auto-reflexivos para a elaboração das inferências e conclusões de pesquisa.

4. Na última parte, a conclusão do trabalho, são colocados os elementos fundamentais os quais a pesquisa alcançou confirmação categórica e as recomendações advindas dos resultados das análises.

\footnotetext{
${ }^{4}$ Falas significativas são as que trazem implícita ou explicitamente algum limite explicativo referente às contradições da realidade concreta dos educandos. Podem ser identificadas em momentos de observação participante ou círculos de investigação temática (Freire, 1968, p. 42).
} 


\section{APORTE TEÓRICO}

\subsection{Formação continuada docente e educação ambiental}

O importante e bonito no mundo é isso: que as pessoas não estão sempre iguais, ainda não foram terminadas, mas que elas vão sempre mudando. Afinam e desafinam. (Rosa, 1994, p. 25)

O volume de professores que atuam na educação básica no Brasil é fruto de variados cursos de licenciatura, que por si só permitem aos seus concluintes a atuação direta com os discentes. Além dos cursos de graduação, existem variados meios de desenvolvimento profissional, em espaços de educação formal e não formal nos quais o ator das funções do magistério pode buscar aumentar, ressignificar e melhorar a sua qualificação.

Um desses meios é a formação continuada permanente, que oportuniza a atualização e melhoria da práxis docente. Mesmo assumindo que o desenvolvimento da atuação dos profissionais da educação depende de uma série de fatores que, para exemplificar, destaca-se a má instrumentalização, a superlotação de turmas, salários insuficientes, longas jornadas de trabalho, e outros elementos que ultrapassam a formação permanente, esta tem potencial para a ressignificação do conhecimento, em um movimento circular de atuação e reflexão.

Ainda que o progresso da formação docente em EA esteja legitimado por políticas e outras normas escritas, existe carência de sua implantação nos cursos de formação continuada (Sato, 2001, p.16), mesmo afirmando que os profissionais de educação em colaboração com pesquisadores externos desempenham uma melhor compreensão da liderança educacional dentro de um contexto específico (Mooler, 1998, p. 73).

Nessa conjuntura, o aumento de ações críticas em EA com práticas educativas mais sustentáveis como escopo, independente do público que se queira atingir, exige conhecimentos que ultrapassam as dimensões isoladas das ciências, dada sua face multidisciplinar (Pedrini e Saito, 2014, p. 37), onde a formação continuada de professores pode ser entendida como uma via possível para superar tal carência.

O ponto de partida para o entendimento do que seriam as práticas mais sustentáveis já mencionadas é a meta da EA descrita pela carta de Belgrado: 
Formar uma população mundial consciente e preocupada com o meio ambiente e com os problemas associados, e que tenha conhecimento, aptidão, atitude, motivação e compromisso para trabalhar individual e coletivamente na busca de soluções para os problemas existentes e para prevenir novos (UNESCO, 1975, p.2).

Neste sentido, a formação de professores pode dirigir seus estudos, planejamentos e práticas de forma que os docentes alcancem uma postura profissional próxima da meta citada, e por consequência, os discentes adotariam sustentabilidade ao seu viver. Sobre este último fator, a presente pesquisa não apresentará resultados categóricos demonstrando tal adoção, mas discutirá possíveis avanços percebidos neste campo.

Para Aquino (2010), se quisermos que o professor promova situações em que o aluno estruture as suas ideias, analise os seus processos de pensamento e resolva problemas, é necessário que ele, em sua trajetória de formação, também tenha vivenciado estas experiências. Ou seja, ele precisa aprender a investigar a sua própria prática, o que remete à pesquisa-ação educacional (Carr e Kemmis, 1986, p. 4).

Em consonância com esse pensamento, Imbernón (2010) afirma que a formação continuada não deve ser vista apenas como atualização, mas como a "criação de espaços de participação e reflexão". Além disso, ela não deve ser meramente teórica, baseada na condução unilateral do conhecimento, pois esse tipo de condução não permite que vivências, experimentações e construção de conhecimentos significativos ocorram de forma integral.

A carência de estudos em EA para professores pode legitimar a formação continuada nesta área, como meio capaz de alcançar qualificação e ressignificação da práxis docente, assegurada pela Lei de Diretrizes e Bases da Educação LDB (Brasil, 1996), que atribuiu aos sistemas de ensino a missão de promover o aperfeiçoamento profissional continuado em variadas temáticas.

Não exclusivamente pela LDB, a formação continuada especialmente em EA, é referenciada na declaração elaborada pela conferência de Tibilisi, em 1977. Ela recomenda "programas de formação complementar que permitam estabelecer relações mais apropriadas sobre uma base interdisciplinar" (recomendação $\mathrm{n}^{0} 11$ ). Adicionalmente, segundo o art. $9^{\circ}$ da PNEA os professores em atividade devem receber 
formação complementar em suas áreas de atuação, com o propósito de atender adequadamente ao cumprimento dos princípios e objetivos desta política (Brasil, 1999), conforme quadro 1.

A busca das dimensões da EA de acordo com princípios e objetivos estabelecidos na Lei 9.795/99 necessita de um desenvolvimento constante na formação dos professores, em suas intenções sistemáticas de melhorar a prática profissional, com o objetivo de aumentar a qualidade da atuação docente, de pesquisa e de gestão (Imbernón, 2010, p. 89).

Entre as referidas dimensões, o despertar de uma visão sistêmica é definido entre os princípios da PNEA por meio do "enfoque holístico, a concepção do meio ambiente em sua totalidade, o pluralismo de ideias e concepções pedagógicas" (art. $4^{\circ}$ par. I, II e II).

Desenvolver uma visão sistêmica em EA e leva-la à sala de aula é uma alternativa para a transformação da realidade - fim da PA -, destacando-se que é delegada à formação continuada criar/oferecer/viabilizar espaços de estudos e reflexões para incluir os professores presentes nas discussões e atualização epistemológica dos conceitos ligados a sociedade e ambiente.

\begin{tabular}{|c|c|}
\hline Documento & Diretrizes/Princípios/Recomendações \\
\hline $\begin{array}{l}\text { Declaração de } \\
\text { Estocolmo } \\
\text { Sobre o Meio } \\
\text { Ambiente } \\
\text { Humano } \\
1972\end{array}$ & $\begin{array}{l}\text { Princípio 19: É indispensável um esforço para a educação em questões ambientais, } \\
\text { dirigida tanto às gerações jovens como aos adultos e que preste a devida atenção ao } \\
\text { setor da população menos privilegiado, para fundamentar as bases de uma opinião } \\
\text { pública bem informada [...] }\end{array}$ \\
\hline $\begin{array}{c}\text { Carta de } \\
\text { Belgrado } \\
1975\end{array}$ & $\begin{array}{l}\text { Diretrizes: 2. A EA deve ser um processo contínuo, permanente, tanto dentro } \\
\text { quanto fora da escola. } \\
\text { 3. A EA deve conter uma abordagem interdisciplinar. }\end{array}$ \\
\hline $\begin{array}{c}\text { Declaração } \\
\text { Conferência de } \\
\text { Tibilisi } \\
1977\end{array}$ & $\begin{array}{l}\text { Recomendação n }{ }^{\circ} 11: \text { A Conferência recomenda que se incitem os membros de } \\
\text { profissões que exercem grande influência sobre o meio ambiente a aperfeiçoarem } \\
\text { sua educação ambiental em: } \\
\text { Programas de formação complementar que permitam estabelecer relações mais } \\
\text { apropriadas sobre uma base interdisciplinar. }\end{array}$ \\
\hline
\end{tabular}




\begin{tabular}{|c|c|}
\hline $\begin{array}{c}\text { Política Nacional } \\
\text { de Educação } \\
\text { Ambiental } \\
1999\end{array}$ & $\begin{array}{l}\text { Art. } 8^{0} \text { As atividades vinculadas à Política Nacional de Educação Ambiental } \\
\text { devem ser desenvolvidas na educação em geral e na educação escolar, por meio } \\
\text { das seguintes linhas de atuação inter-relacionadas: } \\
\text { I - capacitação de recursos humanos; } \S 2^{-} \text {A capacitação de recursos humanos } \\
\text { voltar-se-á para: I) a incorporação da dimensão ambiental na formação, } \\
\text { especialização e atualização dos educadores [...]. } \\
\text { Art. 9-Parágrafo único: Os professores em atividade devem receber formação } \\
\text { complementar em suas áreas de atuação [...]. }\end{array}$ \\
\hline
\end{tabular}

Quadro 1. Diretrizes, princípios, recomendações sobre a EA na formação continuada oriundos de eventos internacionais e a Política Nacional de Educação Ambiental.

Fonte: elaboração própria baseado nos documentos: Declaração de Estocolmo Sobre o Meio Ambiente Humano, 1972; Unesco, 1975; Declaração Conferência de Tibilisi, 1977; PNEA, 1999.

Como levantada nos grandes movimentos em prol da EA no mundo, conforme o quadro 1, na formação de professores a EA deve ser um processo contínuo, permanente e executado por meio de abordagem interdisciplinar. A EA trata de uma mudança de paradigma que implica tanto uma revolução científica quanto política (Sorrentino, 2005, p. 2).

Saito (2012) descreve como um dos desafios da EA:

a necessidade de constante busca do conhecimento baseado no reconhecimento de que o processo de conhecimento da realidade é dinâmico, e as transformações no campo da ciência e da tecnologia exigirão, constantemente, uma readequação dos conhecimentos, sobretudo em função das mudanças na escala e na magnitude dos impactos sociais e ambientais (Saito, 2012, p. 65).

É inegável, portanto, que a formação continuada, enquanto instrumento de uma EA baseada em seus documentos norteadores, tanto nacionais quanto internacionais, tem potencial para consolidar uma nova linha de profissionais frente à dimensão das questões humanos-natureza. Hungerford (2010) chama este profissional de "educador ambiental", capaz de estimular nas pessoas um pensamento crítico e habilidades de participação popular. Para Marcinckowski (2010), trata-se de desenvolver a profissionalização do campo.

Sob o exposto, a promoção de formação continuada em EA aos professores que atuam na educação básica tem relevância científica e social para um possível (e necessário) empoderamento docente inserindo sustentabilidade às ações praticadas. 


\subsection{Pesquisa-Ação educacional}

A pesquisa foi construída nos campos teórico-metodológicos da pesquisa-ação ${ }^{5}$ educacional interligada ao empoderamento concebendo que o desenvolvimento de um alcança o outro.

O primeiro campo, pesquisa-ação, advém da preocupação de unir cada vez mais teoria à ação, fortalecido pelas ciências sociais frente à necessidade de aproximar pesquisas às realidades estudadas para sua transformação. Em ciências exatas por muito tempo tem-se adotado as teorias e metodologias do positivismo no qual o pesquisador define o objeto a ser estudado e como fazê-lo (Saito, 2001, p.131), separando-os.

Uma investigação cujo objeto é o ser humano tem mostrado ao longo dos anos a necessidade de uma abordagem mais horizontalizada entre o pesquisador e os atores participantes de sua pesquisa, uma vez que as situações investigadas compõem a realidade dos envolvidos e que estes manifestam opinião crítica.

Surge assim, a preocupação de desenvolver metodologias de pesquisa de caráter democrático, fundamentada no respeito à participação de grupos sociais nas tomadas de decisão sobre assuntos relacionados ao seu contexto, visando uma transformação social (Toledo e Jacobi, 2013, p. 167). Os estudos do psicólogo norte americano Kurt Lewin na década de 40 são considerados como precursores desse campo.

Em sua atuação, principalmente nas ciências sociais com dinâmica de grupos para integrar as minorias à sociedade dos EUA (Grabauska e Bastos, 1998, p.8), Lewin iniciou nos anos 40 a construção de bases científicas para as ciências sociais por meio de um trabalho prático/empírico. Tais bases descrevem uma nova forma de pesquisar grupos sociais, o qual foi denominado action research, fato que o faz ser considerado como o pai da pesquisa-ação.

No desenvolver desse novo olhar sobre as pesquisas sociais - a pesquisa-ação devem imperar três elementos fundamentais: caráter participatório, impulso democrático e contribuição simultânea para a ciência social e as mudanças sociais (Carr e Kemmis, 1986, 87).

\footnotetext{
${ }^{5}$ Optou-se aqui pela utilização do termo pesquisa-ação, embora se encontre também a expressão investigação-ação. Ambos os termos correspondem ao que se denomina na literatura internacional de action-research.
} 
A participação nesse contexto pressupõe o diálogo entre os atores da investigação, de forma horizontalizada, em abandono à dicotomia pesquisadorpesquisando, fortalecida pelo positivismo. Nesse sentido, experiências em PA devem propiciar espaços de diálogo entre seus pares, prevalecendo confiança mútua e acesso livre aos registros. Para Elliot (1990) apud (Colmenares e Piñero, 2008), a investigaçãoação não pode se estabelecer adequadamente na ausência da confiança, estabelecida pela fidelidade a uma rede ética mutuamente pactuada, a qual governa a coleta, o uso e a difusão de dados.

O caráter democrático, também destacado na obra de Lewin revela uma face importante da PA e que a distingue das práticas positivistas, onde a gestão livre da pesquisa gera comprometimento individual e coletivo, reduzindo (ou eliminando) as sempre presentes relações de poder e garantindo a participação coletiva em todas as etapas da investigação. A teoria Aristotélica registrou que em uma democracia os livres governam (Boobio, 2004, p. 320), ou seja, em uma pesquisa democrática o grupo em conjunto delineia o ir e vir da investigação desfazendo-se de hierarquias e dominações.

Mion e Bastos (2001) observaram que o cultivo de relações democráticas em uma PA permitia a construção de interações dialógicas viabilizando a participação, solidariedade, liberdade, diversidade e igualdade - princípios constitutivos da democracia.

O terceiro caráter Lewiniano de uma PA implica em contribuição e mudança social, onde uma PA antes de tudo deve assumir o compromisso de buscar uma transformação essencialmente coletiva, e nunca individual (Saito, 2001, p. 129), melhorando as realidades, os contextos, o que implica em envolvimento também com questões políticas.

De forma mais prática, porém, não afastada de Lewin (1946), Watts e Jones (2000) contribuem com a temática compreendendo que uma PA teria pelo menos quatro abordagens conceituais gerais: centralidade na resolução de problemas, promoção de parceria e colaboração, mudança de práticas, redefinição ou desenvolvimento de teorias.

Frente às descrições traçadas até aqui, o conceito de PA adotado no presente trabalho é descrito por Carr e Kemmis (1986) como sendo

simplesmente uma forma de inquérito auto-reflexivo empreendido por participantes em situações sociais a fim de melhorar a racionalidade e justiça de suas próprias práticas, suas compreensões sobre essas 
práticas, e as situações nas quais as práticas são realizadas (Carr e Kemmis, 1986, p. 162).

Ao conceber metodologicamente uma investigação como sendo uma PA, seu desenvolvimento deve ser executado em uma espiral de ciclos auto-reflexivos de planejamento, ação, observação e reflexão (Carr e Kemmis, 1986, p.135) conforme figura 1, outrora descritos por Lewin (1946) como planejamento, averiguação e execução.

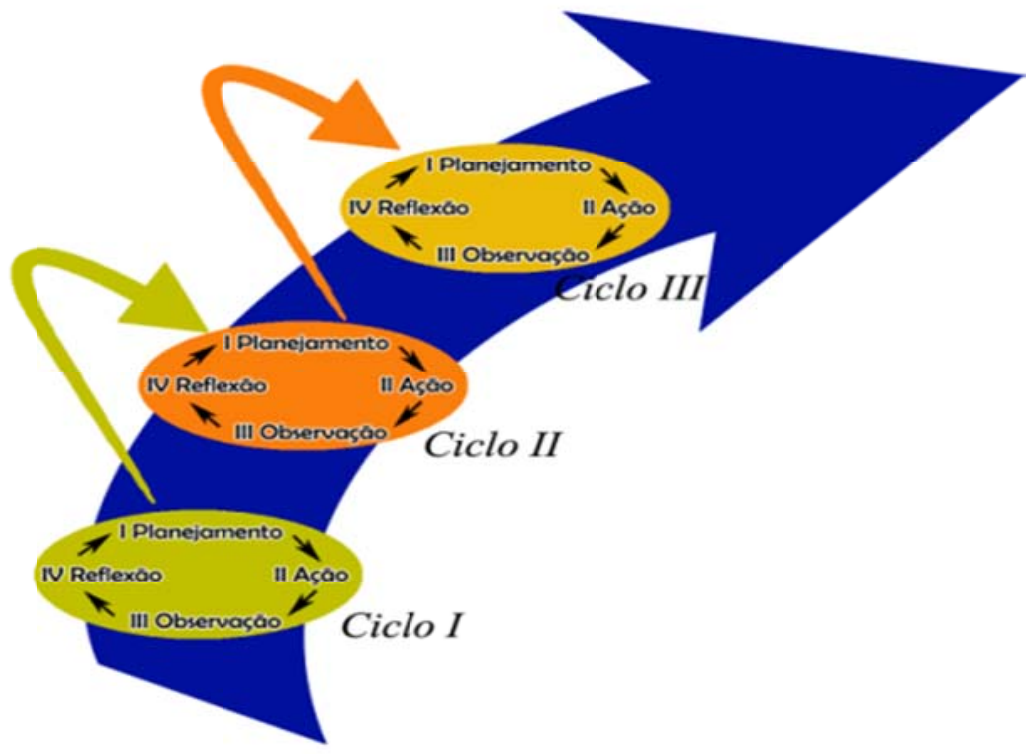

Figura 1. Espiral Lewiniana da pesquisa-ação.

Fonte: Elaboração própria.

Nessa espiral, a autorreflexão presente em todos os ciclos estimula nos participantes um mergulho permanente em sua atuação (profissional, cidadã, técnica etc.) dentro do contexto o qual a investigação se debruça, estimulando uma autocrítica por vezes necessária às transformações sociais.

Carr e Kemmis (1986) chamaram atenção para três questões importantes nas descrições de Lewin que poderiam ser discutidas por especialistas contemporâneos com relação ao significado de pesquisa-ação.

A primeira delas afirma que a tomada de decisão de um grupo é tão importante quanto um princípio mestre, ao invés de uma técnica, sendo essencial no compromisso autentico para a ação social. 
A segunda diz que a

pesquisa-ação não deve ser como um depósito de técnicas para trazer democracia, mas sim uma personificação de princípios democráticos em pesquisa, permitindo aos participantes influenciar, se não determinar, as condições de suas próprias vidas e trabalho, e para desenvolver críticas colaborativamente das condições sociais que sustentam a dependência, desigualdade ou exploração (Carr e Kemmis . 1986, p. 164)

O terceiro ponto diz que a linguagem na qual Lewin descreve o significado teórico e metodológico da ciência social poderia ser descrito como positivista, ou seja, incompatível com o significado e métodos de qualquer ciência social ou educacional adequada.

Nesta altura, faz-se necessário esclarecer que a concepção de pesquisa-ação enquanto técnica descrita por Thiollent (1986), não será ancoradouro da atual pesquisa. Assim como a segunda questão apresentada acima por Carr e Kemmis (1986) que questionava a visão de pesquisa-ação como abordagem somente técnica, Grabauska e de Bastos (2001) discutem a fragilidade de se pensar a PA educativa dentro da racionalidade positivista, calcada na execução de etapas pré-estabelecidas que, apesar de garantir a realização de uma PA, não alcançaria contornos críticos, transformadores e emancipatórios inerentes às realidades investigadas em pesquisas educativas.

O mesmo autor apresenta dois elementos que sustentam o abandono teóricometodológico da conceituação - vinda de Thiollent para a PA educativa, que são i) a tradição da PA como metodologia e ii) a variedade de pesquisa-ação com origem na práxis já disponíveis na literatura nacional e internacional (Grabauska e De Bastos, 2001, p. 13).

Adiante, o surgimento de uma teoria não garante sua completude e sim um primeiro passo, que foi dado por Lewin ao cunhar o termo pesquisa-ação e pô-la em prática. É natural que a incorporação de novos pensamentos ocorram no intuito de melhorar a teoria, mesmo porque os contextos se renovam, olhares e necessidades vão surgindo.

Desta forma, o desenvolvimento da PA, enquanto metodologia de investigação social foi sendo enriquecido paulatinamente nos trabalhos de autores como 
Sol Tax (1958), Fals Borda (1980), Stenhouse (1978), John Elliot (2000), Carr e Kemmis (1986) onde são observadas duas visíveis tendências: uma de cunho mais sociológico cujos participantes eram grupos sociais heterogêneos, e outra educativa, composta por professores e outros membros da comunidade escolar (Santos et al., 2013).

A PA conforme Santos (Santos et al, 2013), pode ser classificada em duas grandes tendências - sociológica e educativa - que estão associadas a um determinado cenário paradigmático como, por exemplo, o positivismo, interpretativismo, emancipação, de onde partem variadas modalidades como, por exemplo, uma PA técnica, prática, crítica/emancipadora, conforme a figura 2.

A segunda tendência, - pesquisa-ação educativa - surge inicialmente como um meio para melhorar a práxis ${ }^{6}$ docente por meio de práticas reflexivas, de cooperação e transformação das ações pedagógicas cotidianas.

A década de 70 permitiu que a PA educativa retomasse fôlego ao vir de uma fase de atraso devido ao modelo positivista que separou a teoria da prática. Sua retomada e fortalecimento se deram com a implementação do Ford Teaching Project in Britain, idealizado por John Elliot e Clem Adelman (Colmenares e Piñero, 2008, 103) cujas bases epistemológicas se ancoravam em Lawrence Stenhouse que acreditava na profissionalização do professor por meio do perfil de pesquisador.

Dentre outros, os principais elementos elencados por Carr e Kemis (1986) para tal ressurgência foram o aumento na demanda de professores que investigavam suas práticas, o interesse pelo currículo, a possibilidade de professores tornarem-se pesquisadores autocríticos de suas práticas, o surgimento de profissionais mais politizados questionadores de suas condições de trabalho, o aumento da solidariedade entre profissionais da educação e melhoria da educação por meio da autorreflexão.

\footnotetext{
${ }^{6}$ Sob a concepção de Vásquez (1977) a práxis é uma atividade conscientemente orientada, o que implica não apenas as dimensões objetivas, mas também subjetivas da atividade advinda da união entre teoria e prática.
} 


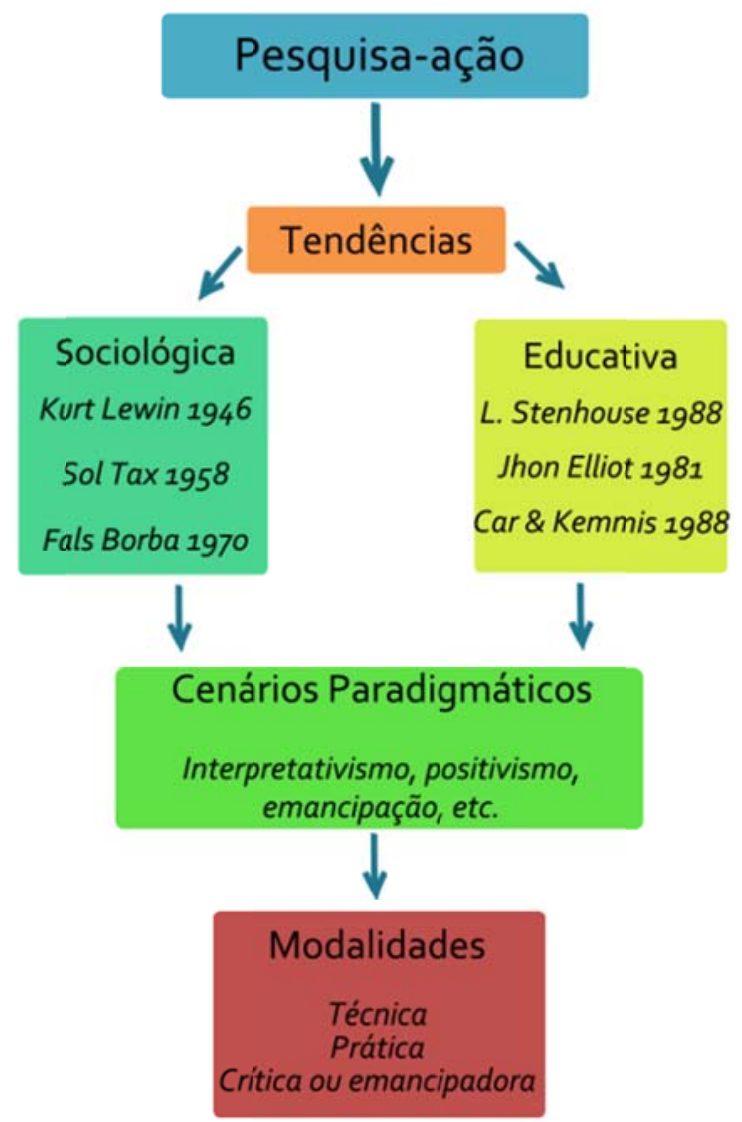

Figura 2: Tendências da pesquisa-ação.

Fonte: Santos et al., 2013.

A situação social estudada pela PA educativa é de cunho educacional, onde o professor é um dos atores fundamentais dessa investigação, com a finalidade da melhoria de suas práticas incorporando um perfil de pesquisador. Para Colmenares e Piñero (2008), a PA educativa figura-se como uma ferramenta epistêmica orientada para a troca de saberes educacionais, pois assume uma postura onto-epistêmica do paradigma sócio-crítico, que parte do enfoque dialético, dinâmico, interativo, complexo de uma realidade que não está dada, mas que está em permanente desconstrução, construção e reconstrução pelos atores sociais.

De forma geral, autores que desenvolveram estudos em pesquisa-ação educacional como Carr e Kemmis (1986), Stenhouse (1978) e Elliot (2000) apontam elementos comuns a esta modalidade investigativa sendo eles:

Objeto de estudo.

i) Atores envolvidos

ii) Intencionalidade 
iii) Procedimentos.

$\mathrm{O}$ objeto de estudo, assim como em qualquer tipo de PA, consiste em um elemento vivido pela sociedade, podendo ser um problema, desafio, conflito, mas que ocorra ou esteja inserido no ambiente escolar. A escolha ou delimitação do objeto se dará por meio das relações dialógicas entre o segundo elemento - atores envolvidosque são além dos profissionais, todos os que estão envolvidos com a realidade do objeto.

Podem existir ainda grupos de investigação onde outras pessoas podem participar como padres, membros das comunidades, estudantes e outros vinculados com o cotidiano escolar. Quando isso não ocorre a PA pode ocorrer individualmente, transformando-se em um processo particular de auto-reflexão (Colmenares e Piñero, 2008, p. 101).

Um grupo constituído por professores e pesquisadores para a promoção de PA educativa, pode ser considerado como uma comunidade investigativa, na qual os participantes desenvolvem atividades em um mesmo contexto social para determinadas situações educacionais.

Grupos com esta conformação implicam em novos relacionamentos entre pesquisadores e os outros participantes,

desenvolve-se um relacionamento colaborativo no qual o pesquisador se torna um amigo crítico que ajuda os envolvidos com informações para agir mais prudentemente, sabiamente e criticamente, nos processos de transformação educativa. Além disso, a parceria com o amigo crítico ajuda os envolvidos nos processos educativos a melhorar suas próprias práticas, suas compreensões sobre si mesmo, e as situações e instituições na qual eles trabalham (Carr e Kemmis, 1986, p. 161).

Como já exposto por Carr e Kemmis, uma pesquisa-ação tem antes de tudo uma finalidade social, portanto, está incorporada a uma intencionalidade que no âmbito educativo, tal intenção seria a melhoria da prática por meio da reflexão e auto-reflexão das ações praticadas junto ao seu contexto, permitindo vinculo entre teoria e prática associado a valores éticos, políticos e educativos.

Encontrados os elementos comuns de uma PA educativa, sua execução se dará em uma espiral de fases seguindo os primeiros escritos de Lewin (1946), mas 
desmembrada em quatro etapas que formam os ciclos da referida espiral de fases, conforme explicitado por Carr e Kemmis (1986) na figura a seguir.

\section{Os momentos da pesquisa-ação}

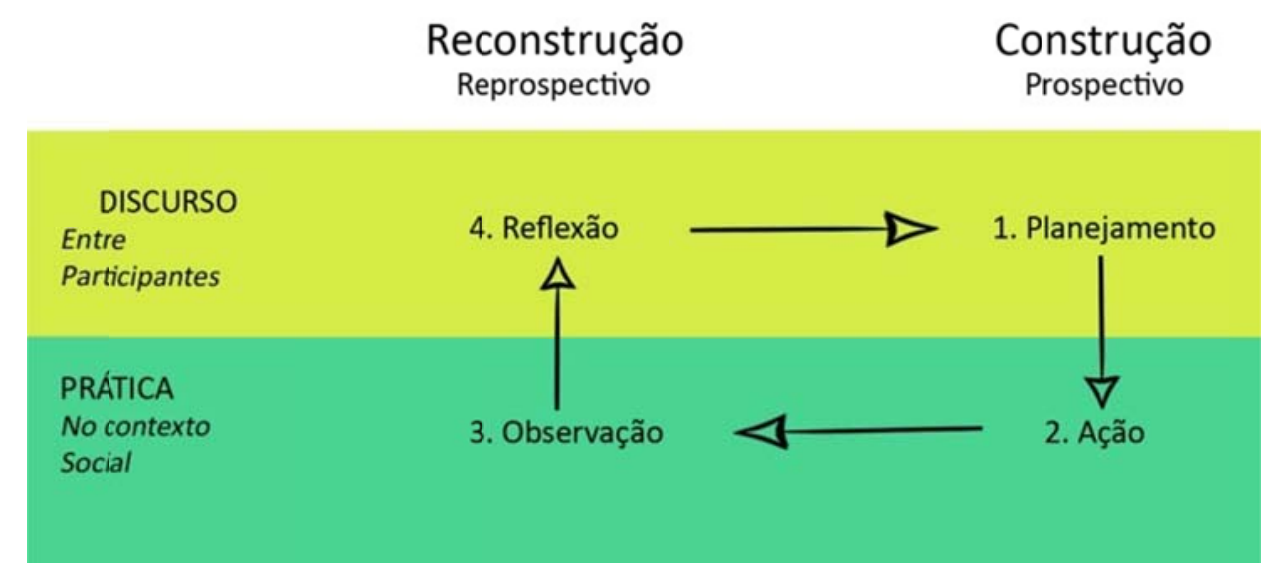

Figura 3: Os momentos da pesquisa-ação.

Fonte: Carr e Kemmis (1986).

À medida que a PA se estabelecia nos ambientes de pesquisa, ocorria paralelamente uma forma de pesquisa educacional que conseguiria marcar para sempre visões sobre teoria e prática educacional. O professor Paulo Freire apresentou contribuições com um olhar crítico, problematizador e emancipatório da realidade por meio de obras como Pedagogia do Oprimido (1968), Educação como prática da liberdade (1983), fortalecendo a questão de que práticas dialógicas teriam potencial para problematizar a realidade vivida, conduzindo seus pares a um fortalecimento pessoal e de grupo para modificar uma determinada situação.

Mesmo não sendo Freire um autor específico de pesquisa-ação, suas obras contribuem para o desenvolvimento dessa modalidade investigativa e para o surgimento da emancipação como novo cenário paradigmático, mostrando a necessidade da transformação de realidades educacionais por meio de uma pedagogia dialógica considerada por Grabauska e Bastos (2001) como uma "teoria da ação" em educação, em desapego às práticas chamadas por Freire (2011) como bancárias, reafirmando o caráter transformador de metodologias participativas como a própria pesquisa-ação.

O delineamento dado por Lewin sobre a pesquisa-ação, incorporado às questões discutidas por Freire (2011) relacionadas a vivências dialógicas entre os seus atores, a intencionalidade emancipatória e a dimensão política, engendram uma pesquisa-ação 
defendida por alguns autores (Carr e Kemmis, 1986; Grabauska e Bastos, 1998; Saito, 2001) e que potencializa a incorporação da EA em seus princípios e objetivos, por exemplo, descritos na Política Nacional de Educação Ambiental.

De acordo com Tozoni-Reis e Vasconcellos (2014, p. 114), as relações entre humanos e natureza devem possibilitar um posicionamento que supere as abordagens científicas pautadas pela racionalidade neutra e objetiva, sem descartar o rigor científico. Assim, uma abordagem de pesquisa-ação permite um novo olhar sobre as relações homem-natureza, exercitando o pensar sobre os elementos constituintes dessas relações em uma hermenêutica ambiental. Os sujeitos, ao serem desafiados pela problematização, ampliam a sua compreensão, ligando um desafio a outro, em um plano sistêmico que resulta na crescente compreensão crítica do mundo.

O pensamento e reflexão alinhados à compreensão crítica do mundo se dão concomitantemente às ações praticadas, como Freire (2011) ratifica: “os homens são seres da práxis", e embora a pesquisa-ação educativa apresente momentos reflexivos e interpretativos, a realização de ações é fator sine qua non para sua existência.

A amplitude de uma EA crítica capaz de problematizar a realidade tem potencial para a realização de ações positivas corporificadas pela pesquisa-ação e instrumentalização dos atores e grupos sociais. Estes sujeitos assim fortalecidos alcançam empoderamento que, por sua vez, está ligado a uma intencionalidade de promover a união dos conhecimentos e práticas acadêmicos e culturais em vetores topdown e bottom-up, para que ambos se retroalimentem, inserindo ciência na cultura ${ }^{7}$, como proposto por Bazin (1998).

Por fim, assumir a EA conforme seus princípios legais requer práticas que propiciem uma dialogicidade e problematização crítica entre os atores que dela participam, o que pode ser buscado partindo da organização heurística do ciclo planejamento - ação - observação - reflexão.

\footnotetext{
${ }^{7}$ Para Maurice Bazin "uma sociedade ser tecnologificada não significa que as tecnologias entraram na cultura do povo daquela sociedade". Para o autor é necessário que as pessoas se apropriem dos conhecimentos científicos e de seus mecanismos de funcionamento. Em contrapartida, a ciência deve se abrir à compreensão popular de seus elementos, na perspectiva de surgir uma cultura da ciência composta por pessoas que se apropriam da ciência, de seu funcionamento e que sejam capazes de compreender criticamente estes elementos.
} 


\subsection{O percurso da pesquisa-ação conduz ao empoderamento docente.}

O segundo campo teórico no qual se ancora a presente pesquisa é o do empoderamento. Originalmente, o termo foi descrito na língua inglesa empowerment já se encontrando sua tradução em dicionários da língua portuguesa e em trabalhos acadêmicos como Lisboa (2000).

Mesmo tendo iniciado em discursos e relatos feministas (Rappaport, 1995, p. 799), empoderamento tem sido buscado em variadas áreas do conhecimento além de discursos culturais divergentes, tornando-se um elemento polissêmico (Horochovski, 2006, p. 5), por vezes adaptado às especificidades do ambiente em que ele estiver sendo tratado. Dada a versatilidade do elemento é significativo destacar que nem sempre o que se chama de empoderamento é o que realmente acredita-se nesta pesquisa como sendo.

Uma prática que conduza, por exemplo, ao fortalecimento econômico de minorias elitizadas já favorecidas histórica e politicamente, não pode ser considerada como geradora de empoderamento, pois perpetua a desigualdade e contribui para a manutenção do status quo, desfavorecendo cidadãos e populações em seus direitos e liberdades.

Destarte, a descrição de Saito (2001), a partir dos escritos de Friedmann (1992) sobre empoderamento, aqui empregada, relata que

$$
\begin{aligned}
& \text { pode-se entender por empoderamento como sendo um fortalecimento } \\
& \text { político-organizacional de uma coletividade, que se auto-referencia } \\
& \text { nos interesses comuns e pratica uma ação solidária e colaborativa para } \\
& \text { transformar a realidade local e desenvolvê-la social e economicamente } \\
& \text { (Saito, 2001, p. 127). }
\end{aligned}
$$

Com destaque ao fortalecimento político-organizacional descrito acima, é necessário afirmar que a participação do Estado é sine qua non dentro dessa noção, uma vez que o empoderamento "ideal" ou mais "completo" surge em uma coletividade, e, em um contexto "ideal" deveria avançar em escalas, passando para instituições, sociedade, Estado, avançando nas fontes de poder - social/econômico, político e psicológico - elencados por Friedmann (1996). 
Tais fontes de poder emergem em uma perspectiva de que o empoderamento se dá paralelamente ao desenvolvimento ${ }^{8}$ dos atores envolvidos, sendo i) o poder social/econômico - o acesso a informações e recursos (quantificáveis) para o alcance dos objetivos almejados, ii) o poder político - o acesso aos processos de tomada de decisão em uma situação de democracia e acesso ao "capital social", iii) poder psicológico - crença do indivíduo de que é capaz de utilizar de empoderamento para suas ações (Horochovski, 2006, p. 13).

Os fundamentos envolvidos no desenvolvimento de uma pesquisa-ação se entrelaçam ao conceito do empoderamento, no sentido de que trabalhos que permitem uma dialogicidade problematizadora tendo uma transformação social como objetivo, no seu decorrer, podem alcançar um melhoramento intelectual como prática da liberdade, política e organizacional de uma coletividade.

\subsection{Do desenvolvimento sustentável para práticas educativas sustentáveis: travessias.}

A década de 60 trouxe um alerta para a abordagem do homem perante a natureza com a publicação de Silent Sprin por Carson (1962), fortalecendo e impulsionando um fenômeno social, econômico e político global: o movimento ambientalista (McCormick, 1992, p. 39). Ainda que na atualidade críticas possam ser tecidas sobre as poucas mudanças na gestão humana do meio ambiente, Rachel Carson conseguiu chamar a atenção social e política para a existência de limites ecológicos.

Preocupações anteriores já existiam com os grupos preservacionistas e conservacionistas no séc. XIX, porém, o chamado Novo Ambientalismo ${ }^{9}$ foi marcante por agregar à percepção científica a noção de interferência humana na natureza e estimular o pensamento humano sobre a adequação de seu modo de vida às capacidades e resiliências ambientais.

\footnotetext{
${ }^{8}$ Não se concebe aqui a noção da economia clássica que considera PNB como medida de desenvolvimento. Compartilha-se da concepção de desenvolvimento descrita na obra de Amartya Sen Desenvolvimento como prática de liberdade - na qual o novo modelo de desenvolvimento, baseado na expansão das liberdades sociais, vê o desenvolvimento como um processo de expansão das liberdades substantivas das pessoas. SEN, A. Desenvolvimento como liberdade. São Paulo: Companhia das Letras, 2010.

${ }^{9}$ Entre 1962 e 1972 surge o que foi chamado de Novo Ambientalismo - um movimento social/político que levantou questões universais estimulado pela era atômica e dos químicos tóxicos, destacando-se o impacto gerado pela obra de Carson e a constituição do Clube de Roma.
} 
Até então, a visão antropocêntrica e baconiana ${ }^{10}$ da natureza estavam fortes na mentalidade humana, ou pelo menos, não tinham sido expostos (por meio de linguagem simples e acessível) tantos argumentos e exemplos ${ }^{11}$ claros dos malefícios causados pelas ações humanas ao meio ambiente.

Algumas discussões sucederam a obra entre os anos 60 e 70, e durante esses processos, a corrente pessimista liderada por autores como Meadows, Marx, Malthus, Stuart Mill, Hardim, Engels, Ehrlich (McCormick, 1992, p.112) junto às publicações do Clube de Roma ${ }^{12}$, incentivaram debates devido as suas previsões catastróficas de um futuro com previsão de escassez, fome, não desenvolvimento, de acordo com The limits to growth,

se as atuais tendências de crescimento da população mundial industrialização, poluição, produção de alimentos e diminuição dos recursos naturais - continuarem imutáveis, os limites de crescimento neste planeta serão alcançados algum dia dentro dos próximos cem anos. O resultado mais provável é um declínio súbito e incontrolável, tanto da população quanto da capacidade industrial (Meadows, 1973, p. 20).

Neste contexto, as novas manifestações e preocupações conduziram à realização da Conferência de Estocolmo em 1972, como marco do surgimento de uma nova conscientização que questionava a visão compartimentada e unilateral dos processos sociais que privilegiava o enfoque economicista de desenvolvimento (Filho, 1993, p.140).

\footnotetext{
${ }^{10}$ Francis Bacon (séc. XVII) - Considerado como um dos fundadores da ciência moderna, o filósofo e político inglês afirmava que o conhecimento da natureza daria aos homens plenos direitos à sua dominação e exploração.

${ }^{11}$ Após uma introdução, o livro fala dos produtos químicos em geral e de seu poder de toxicidade e entra em vários capítulos com definições e vários exemplos sobre a ação dos produtos tóxicos sobre a água, $o$ solo, o manto verde (plantas), aves, mamíferos, os organismos do solo, o homem. O título do livro parte da observação feita em várias cidades dos Estados Unidos após a pulverização de produtos tóxicos que mataram parte da fauna e flora, em especial as aves. E, quando chegou a primavera após os ataques, nenhuma ave cantou, a primavera veio silenciosa.

${ }^{12}$ Clube de Roma - Em 1968 constituiu-se o Clube Roma, composto por 30 personalidades ilustres de diferentes nacionalidades (cientistas, industriais, políticos, pensadores, acadêmicos, empresários, economistas, educadores), que tinham como objetivo pensar os dilemas da humanidade (econômicos, políticos, sociais, culturais, ambientais) enfocando posteriormente o crescimento econômico frente aos limites dos recursos naturais (http://www.clubofrome.org/?p=703).
} 
No cerne das discussões, surge a necessidade de outro padrão de desenvolvimento, rechaçando o anterior e incluindo outras dimensões. Ignacy Sachs difundiu o termo ecodesenvolvimento, porém no relatório Brundtland o termo Desenvolvimento Sustentável (DS) foi confirmado e compreendido como um desenvolvimento que responde às necessidades do presente sem comprometer as possibilidades das gerações futuras de suprir suas próprias necessidades (Brundtland, 1987, p. 122).

A hercúlea convergência das ideias e necessidades surgidas para o desenvolvimento sustentável, dada a sua abrangência e conceituação plástica, conseguiu chegar a um consenso, no qual o esforço de unir as dimensões social, econômica e ambiental deve ser o mínimo para se conceber essa forma de desenvolvimento. Sachs, na defesa do desenvolvimento endógeno e fuga ao mimetismo cultural $^{13}$, amplia essas dimensões estabelecendo critérios para a sustentabilidade: o social, cultural, ecológico, ambiental, territorial, econômico, política/nacional e internacional (Sachs, 2009, p. 35).

O discurso do desenvolvimento sustentável paulatinamente foi se ampliando nos variados campos do saber gerando uma tomada de consciência coletiva, que por si não foi suficiente para clarear quais conhecimentos e ações seriam adequados ao enfrentamento dessa nova constatação.

Neste contexto, o importante papel da educação ambiental se afirma, no compromisso de orientar, informar e conscientizar de forma crítica, as relações entre os seres humanos e a natureza, visando a promoção de um modo de vida que insira atitudes mais sustentáveis.

A educação como Sachs (2008) afirma,

é um fator essencial para o desenvolvimento includente, pelo seu valor intrínseco, na medida em que contribui para o despertar cultural, a conscientização, a compreensão dos direitos humanos, aumentando a adaptabilidade e o sentido da autonomia, bem como a autoconfiança e a auto-estima (Sachs, 2008, p. 82).

\footnotetext{
${ }^{13}$ Vale destacar que a contraposição ao mimetismo cultural descrito por Sachs reforça e complementa o pensamento outrora colocado por Furtado ao afirmar que a apropriação mundial do modelo de desenvolvimento dos países de centro seria um mito FURTADO, C. O mito do desenvolvimento Econômico. Rio de Janeiro: Paz e Terra, 1996.
} 
No Brasil, as responsabilidades da educação ambiental após o surgimento do discurso do desenvolvimento sustentável se acirraram, talvez devido à escassez de dados sobre o seu desenvolvimento (Lima, 2003, p. 103), mesmo assim, ao se tratar de educação ambiental e sustentabilidade, os registros do I CNEA apresentam algumas problemáticas que devem ser superadas, conforme o quadro 2.

\begin{tabular}{|c|c|}
\hline Tema & Problemática \\
\hline \multirow{7}{*}{$\begin{array}{l}\text { Educação ambiental e as } \\
\text { vertentes do } \\
\text { desenvolvimento } \\
\text { sustentável }\end{array}$} & $\begin{array}{l}\text { - A existência de diferentes conceitos de desenvolvimento sustentável } \\
\text { dificulta a informação e sua compreensão. }\end{array}$ \\
\hline & $\begin{array}{l}\text { - O modelo de desenvolvimento adotado dá prioridade às questões } \\
\text { econômicas. }\end{array}$ \\
\hline & $\begin{array}{l}\text { - O sistema produtivo é marcado por um modelo econômico agro-exportador } \\
\text { que não viabiliza o desenvolvimento de práticas sustentáveis e acaba } \\
\text { estimulando práticas consumistas. }\end{array}$ \\
\hline & $\begin{array}{l}\text { - O setor acadêmico deve se comprometer, institucionalmente, quanto ao seu } \\
\text { papel de gerar conhecimentos; fundamentar as práticas de educação; criar } \\
\text { metodologias e material didático e realizar pesquisas sobre tecnologias } \\
\text { alternativas para o desenvolvimento sustentável. }\end{array}$ \\
\hline & $\begin{array}{l}\text { - A necessidade de estabelecer, na prática, uma política de educação ambiental } \\
\text { para o país com adequação às realidades regionais, estaduais e municipais. }\end{array}$ \\
\hline & $\begin{array}{l}\text { - A necessidade de incentivar práticas de educação ambiental que privilegiem } \\
\text { uma contextualização sócio-econômica e cultural da realidade. }\end{array}$ \\
\hline & $\begin{array}{l}\text { - A falta de articulação entre as ações dos diversos setores do poder público, } \\
\text { associada à falta de integração regional e da sociedade civil, e à ausência da } \\
\text { interinstitucionalidade e interdisciplinaridade, bem como a insuficiência de } \\
\text { recursos humanos capacitados e financeiros, têm relegado a educação } \\
\text { ambiental a um segundo plano. }\end{array}$ \\
\hline
\end{tabular}

Quadro 2: Problemáticas relacionadas à educação ambiental e às vertentes do DS no Brasil.

Fonte: BRASIL, 1997.

As problemáticas destacadas no quadro acima podem ser resumidas pelo modelo mecanicista de educação vigente, à predominância dos padrões de desenvolvimento economicista e à falta de articulação entre os diversos setores componentes da sociedade. Tudo isso, confere aos educadores comprometidos com a EA o desafio não só de levar à compreensão do polissêmico conceito de DS como de imergi-lo nas práticas educativas. 
A referência basilar que orienta as práticas e atitudes mais sustentáveis buscadas no presente estudo incorporam a meta para a educação ambiental estabelecida pela carta de Belgrado $^{14}$. Em seu texto final, o documento estabelece como meta

Formar uma população mundial consciente e preocupada com o meio ambiente e com os problemas associados, e que tenha conhecimento, aptidão, atitude, motivação e compromisso para trabalhar individual e coletivamente na busca de soluções para os problemas existentes e para prevenir novos (UNESCO, 1975, p. 2).

O burilamento da meta revela interfaces com os critérios para a sustentabilidade afirmados por Sachs (2009) e o conceito de desenvolvimento sustentável formulado no relatório Brundtland (Meadows, 1987, p. 122). No primeiro à medida que uma população torna-se consciente com o meio ambiente e seus problemas associados, inexoravelmente vai admitir as dimensões social, cultural, ecológico, ambiental, territorial, econômico, política/nacional e internacional.

É possível que à primeira vista todas as dimensões que conduzem à sustentabilidade, descritas por Sachs, não sejam reveladas, considerando que a natureza do problema ambiental influencia as dimensões. É a partir do exercício do planejamento - ação/observação - reflexão, ainda que nos campos epistêmicos, que as dimensões têm potencial de serem despontadas.

A segunda interface da meta se dá com o conceito de DS que considera sustentável o desenvolvimento que responde às necessidades do presente sem comprometer as possibilidades das gerações futuras de suprir suas próprias necessidades, na medida em que a meta de Belgrado preconiza a busca de soluções para os problemas existentes e para prevenir novos.

Existe nesta última afirmação uma solidariedade sincrônica e diacrônica em um imperativo ético com as questões sociais e ambientais (Sachs, 2009, p. 37). Ainda que

\footnotetext{
${ }^{14}$ Em resposta às recomendações da Conferência de Estocolmo, A UNESCO promoveu em Belgrado (Iugoslávia) um Encontro Internacional em Educação Ambiental onde criou o Programa Internacional de Educação Ambiental - PIEA que formulou os seguintes princípios orientadores: a Educação Ambiental deve ser continuada, multidisciplinar, integrada às diferenças regionais e voltada para os interesses nacionais.
} 
as interfaces estejam postas, existe a compreensão realista de que os preceitos do ecodesenvolvimento e do DS apresentaram alvos divergentes.

A marca do primeiro é o compromisso com os direitos e desigualdades sociais e com a autonomia dos povos e países menos favorecidos na ordem internacional e o segundo em suas estratégias de resistência à mudança da ordem econômica, dissolveu o potencial crítico e transformador das práticas de ecodesenvolvimento e configurou um conceito de DS que foi capaz de ecologizar a economia, eliminando a contradição entre crescimento econômico e preservação da natureza (Lima, 2003, p. 107).

Ademais a meta estabelecida pela Conferência considera a necessidade de formar cidadãos com conhecimento, aptidão, atitude, motivação e compromisso para o trabalho que envolve o meio ambiente. Neste campo, diante da variedade de conhecimentos e concepções apresentadas nos discursos de sustentabilidade, o entendimento crítico das situações unido à alfabetização científica tem maiores chances de assegurar a coerência e proximidade das ações praticadas e refletidas à literatura, na tentativa de eliminar o reprodutivismo acrítico de projetos e ações em EA.

A busca por práticas sustentáveis aqui investigada, se aproxima mais do pensamento do ecodesenvolvimento, em seus aspectos emancipadores dos atores envolvidos e absorve a necessidade de desenvolvimento, alinhada às contribuições de Amartya Sen, que em resumo considera o desenvolvimento como

a efetivação universal do conjunto de dos direitos humanos, desde os direitos políticos e cívicos, passando pelos direitos econômicos, sociais e culturais, finalizando nos direitos ditos coletivos, entre os quais está o direito a um meio ambiente saudável (Sen, 2010, p. 55).

A superação dos desafios de compreensão conceitual e prática para a inserção de atitudes sustentáveis exige uma metodologia que funcione em um sistema aberto, que seja democrática e participativa, uma vez que diferentes rumos podem ser tomados no decorrer do seu desenvolvimento a fim de elucidar as lacunas que possam surgir.

Nesse compromisso, a pesquisa-ação poderá ser o lastro teórico-metodológico capaz de desenvolver educação ambiental crítica, democrática e transformadora de realidades para um fortalecimento docente que conduza os discentes à realização e incorporação de práticas sustentáveis. 


\section{METODOLOGIA}

\subsection{O surgimento da pesquisa}

A trajetória acadêmica e profissional da pesquisadora, assim como o curso de um rio, conduziram as múltiplas variáveis que a constituem para a realização deste trabalho. A graduação em Biologia e a atuação docente na Secretaria de Educação do Distrito Federal (SEDF) despertaram um olhar mais atento às questões que envolvem o homem e o meio ambiente especialmente na esfera educativa.

O fator determinante para a realização da pesquisa correspondeu a uma experiência vivida pela autora na formação docente, por meio da política interna de formação continuada aos professores que a SEDF desenvolve em sua Escola de Aperfeiçoamento dos Profisssionais da Educação (EAPE).

A SEDF oferece anualmente ao seu corpo docente cursos, fóruns e seminários de formação continuada, em consonância com o Decreto $n^{0} 6.755$ de 29 de janeiro de 2009 (Brasil, 2009) e as demandas da rede pública de ensino do DF, em busca de uma melhor qualidade da educação e valorização profissional dos educadores.

A diversidade de temáticas envolvendo as questões educacionais subdividiu a EAPE em núcleos menores, porém, interligados. Um deles ganhou destaque neste trabalho: a Oficina Pedagógica (OP).

A Oficina Pedagógica ${ }^{15}$ é um núcleo destinado à formação continuada dos profissionais da educação que oferece cursos e oficinas temáticas voltadas aos docentes das escolas públicas. Pela natureza da organização territorial do DF, dividido em regiões administrativas (RA), e na busca de se aproximar dessa divisão, as OPs estão subdivididas em filiais distribuídas por 14 RAs. Dentre elas, a OP situada na RA-XV, referente à cidade Recanto das Emas foi contexto geográfico de um curso de formação continuada denominado Educação Ambiental Lúdica (EAL).

\footnotetext{
15 Oficinas Pedagógicas são espaços destinados à formação continuada dos profissionais de educação, apoiando a pesquisa, o estudo, a criação, o desenvolvimento de recursos lúdicos e posturas pedagógicas mais criativas, flexíveis e humanizadas, além de possibilitar a produção de materiais lúdico-pedagógicos como recursos didáticos que favorecem os processos de ensinar e de aprender. (Brasília, 2012).
} 
A referida formação foi planejada e ministrada pela presente pesquisadora, e realizada na Oficina Pedagógica do Recanto das Emas, contando com a participação de 19 cursistas atuantes na educação básica pela SEDF.

O objetivo da formação EAL foi desenvolver uma EA crítica, de modo a propiciar uma formação que estimule uma práxis docente dialógica. Um vivenciar pedagógico, por meio da construção e uso de materiais concretos capazes de estimular a criatividade, impulsionou a reflexão e ação no curso, buscando o que Freire (2011, p. 76) chamou de transformação criadora.

O curso em questão se fortaleceu através de abordagens e instrumentalizações lúdicas, com o uso de jogos e produções manuais articulados à teoria para gerar uma práxis, uma vez que ela é uma atividade conscientemente orientada, o que implica não apenas as dimensões objetivas da atividade, mas também dimensões subjetivas (Vásquez, 1977, p. 33).

A carga horária se dividiu em horas diretas por meio de aulas expositivas e indiretas, preenchidas por estudos, redação de um projeto interdisciplinar, diário de bordo e a construção de um portifólio individual.

As figuras 4 a 6 expõem algumas ações desenvolvidas ao longo da formação como leituras de textos e artigos científicos, discussões, troca de experiências entre os docentes, uso de jogos, confecções de materiais pedagógicos e uma saída de campo ao Parque Ecológico e Vivencial do Recanto das Emas - PEVRE ${ }^{16}$.

A análise dos dados recolhidos durante o curso EAL explicitou que embora a formação tenha obtido conceito excelente conforme os critérios avaliativos dispostos na ficha de avaliação do curso fornecida pela EAPE, a carga horária foi insuficiente diante da complexidade da EA.

O fator dificultou a execução de projetos e/ou sequências didáticas pelos participantes concomitantemente ao curso, não oportunizando o acompanhamento pelo formador de projetos os quais os professores poderiam realizar nas escolas e principalmente de pesquisa-ação.

\footnotetext{
${ }^{16}$ Criado pela Lei ${ }^{0} 1.188$ de 13 de setembro de 1996 e conhecido também como Parque Monjolo.
} 


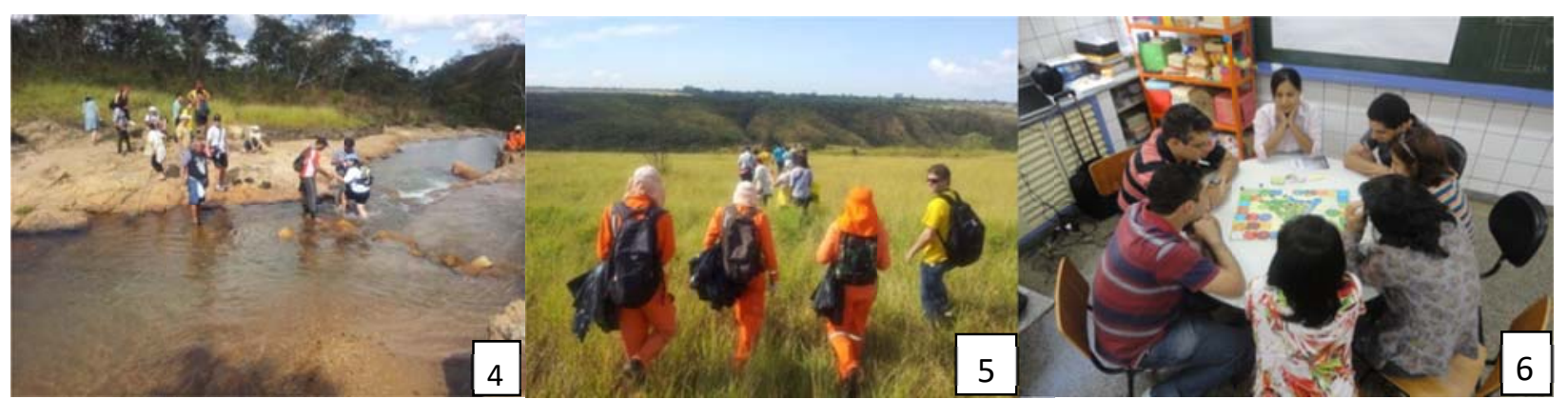

Figuras 4 e 5: saída de campo ao Parque Ecológico e Vivencial do Recanto das Emas; figura 6: cursistas jogando o Probio/ Ecol. UnB/MMA, 2006.

Os fatos indicaram para a formadora a necessidade de desenvolver estudos individuais mais aprofundados e a adequação de metodologias compatíveis ao desafio da Educação Ambiental conforme sua amplitude, princípios e objetivos delimitados nos documentos das conferências, acordos e políticas vigentes.

Unindo a necessidade individual de profundar estudos à trajetória formativa e subjetiva, a pesquisadora ingressou como aluna especial da disciplina de educação ambiental do CDS e na sequencia, o ingresso como aluna regular do curso de mestrado em Desenvolvimento Sustentável do CDS-UnB e à realização desta pesquisa.

Para dar sequência aos estudos outrora desenvolvidos com os professores no curso EAL, foi feito um convite aos cursistas para participarem do projeto de pesquisa e constituírem uma Comunidade Investigativa (CI) que desenvolveria uma pesquisa-ação em educação ambiental no ambiente educativo que eles estivessem atuando.

A maioria dos professores manifestou interesse em participar, porém dadas as variadas condições de turno, distância geográfica, questões de saúde, aposentadorias e lotação em cargos de confiança, foi possível para somente um professor que participou da formação EAL, constituir junto com a pesquisadora uma comunidade investigativa (CI).

Nos termos de Carr e Kemmis (1986), em uma pesquisa-ação educativa a comunidade investigativa é constituída por professores e pesquisadores, além dos demais atores envolvidos com a realidade do objeto, no qual os participantes desenvolvem atividades em um mesmo contexto social para determinadas situações educacionais.

O nome do participante da comunidade investigativa será resguardado, e a referência adotada para a sua pessoa será PROFESSOR REGENTE. Este tem graduação 
em geografia e atua no magistério ha oito anos, sempre ministrando a disciplina de geografia para as séries finais do ensino fundamental e ensino médio, nas redes pública e privada da educação.

Para a execução da pesquisa, além da aceitação do professor regente em participar, o projeto foi registrado pelo número 54191716.9.0000.5540 no Comitê de Ética e Pesquisa em Ciências Humanas e Sociais - CEP/UnB, autorizado pela EAPE conforme documento no anexo 1, autorizado pela CRE Recanto das Emas conforme anexo 2 e, por fim, conferido e autorizado pela gestora da escola envolvida na pesquisa (anexo 3).

\subsection{O território, os atores e a pesquisa-ação desenvolvida.}

Constituída a comunidade investigativa foi desenvolvida entre os meses de maio a setembro de 2016, uma pesquisa-ação em educação ambiental. A concepção inicial da comunidade foi desenvolver um projeto cujo objeto envolvesse uma questão socioambiental, alinhada ao segundo princípio postulado na PNEA, que enfatiza "a concepção do meio ambiente em sua totalidade, considerando a interdependência entre o meio natural, o socioeconômico e o cultural, sob o enfoque da sustentabilidade" (BRASIL, 1999, art. 4, par. II). Para tanto alguns temas foram discutidos até chegar ao consenso de que a temática central seria o combate à dengue, dada a sua atualidade, relevância socioambiental e interfaces multidisciplinares.

O projeto foi realizado pela comunidade investigativa em cinco turmas dos oitavos anos do ensino fundamental/séries finais, nas quais o professor regente leciona. A faixa de idade dos alunos participantes variou de 12 a 14 anos, e em média, cada turma continha 20 alunos frequentes, em um total de aproximadamente cem estudantes do turno matutino.

A escola envolvida, o Centro de Ensino Fundamental 602 do Recanto das Emas (CEF 602), foi o território que acolheu o projeto. A cidade a qual a escola faz parte foi criada em julho de 1993 para atender uma demanda de moradia do Programa de Assentamento do Governo do Distrito Federal, e recebeu o nome Recanto das Emas em função da grande quantidade de planta característica do cerrado chamada Canela de Ema, além de ter um sítio chamado Recanto. 
O Centro de Ensino Fundamental 602 foi inaugurado no final de 2004 e desde a sua fundação até os dias atuais sua comunidade é composta por famílias trabalhadoras. Conforme o Projeto Político e Pedagógico (PPP) do CEF 602, um dos principais problemas enfrentados pela comunidade escolar é a violência, ocorrendo pontuais ameaças e brigas entre gangues nas imediações da escola, fator agravado pela ausência de policiamento permanente na comunidade.

O PPP revela que é princípio educacional da escola a adoção de uma proposta educacional emancipadora, o que permite uma interface com a pesquisa-ação, compreendendo-se que práticas educativas que promovem a reflexão e contextualização de questões científicas, a dimensão política e a intencionalidade emancipatória podem resultar no empoderamento dos atores envolvidos (Grabauska e Bastos, 1998, p. 7).

As atividades do projeto ocorreram em sua maioria nos horários das aulas de geografia, que dispõe de três aulas por semana nas turmas de oitavo ano com duração de cinquenta minuto cada aula. Para cada ciclo realizado no projeto, os planejamentos e reflexões ocorreram no contraturno com a participação da comunidade investigativa, nos tempos denominados coordenação pedagógica (espaço anualmente garantido aos docentes por força de portaria).

A justificativa do tema escolhido envolveu a direção tomada pelas campanhas nacionais e locais de combate à dengue e levantou a seguinte hipótese: a ideologia de combate exclusivo ao Aedes aegypti difundida pelas campanhas brasileiras oficiais de combate à dengue, leva a um conhecimento insuficiente/deturpado sobre o ciclo da doença e das medidas preventivas possíveis.

Para investigar a hipótese levantada, o projeto traçou os seguintes objetivos:

Objetivo Geral: Levantar as origens e principais influências sobre os conhecimentos dos alunos dos oitavos anos do ensino fundamental do CEF 602 do Recanto das Emas sobre a dengue; analisar as ideologias que envolvem as campanhas governamentais (nacionais e regionais) e sua eficácia no combate à epidemia para propor melhores formas de prevenção.

Objetivos Específicos:

I) Diagnosticar os conhecimentos prévios dos alunos dos oitavos anos do ensino fundamental do CEF 602 do Recanto das Emas sobre a dengue, por meio de questionário.

II) Informar os alunos sobre a dengue por meio de palestra. 
III) Expor interdisciplinarmente conhecimentos geográficos, históricos, biológicos e ecológicos sobre a dengue.

IV) Debater junto ao público envolvido as ideologias difundidas pelas campanhas oficiais de combate à dengue no Brasil.

V) Identificar possíveis conflitos e/ou situações que envolvam a temática com e na comunidade escolar para propor ações positivas.

VI) Produzir um folder com formas de prevenção mais completas.

O projeto foi realizado seguindo as etapas da espiral-cíclica Lewiniana da pesquisa-ação educacional - planejamento, ação, observação e reflexão. As fases do discurso entre participantes de planejamento e reflexão ocorreram principalmente nas coordenações pedagógicas e via e-mail pela comunidade investigativa.

Em cada ação desenvolvida elaborou-se um plano de aula, que foi retomado nas fases de reflexão para o planejamento ou replanejamento do próximo ciclo. Foram realizados um total de dez ciclos que juntos constituíram a espiral cíclica da pesquisaação em EA, de acordo com o quadro 3.

\begin{tabular}{|c|c|c|c|}
\hline Ciclo & DATA & ATIVIDADE & Materiais/Método \\
\hline $\mathbf{1}^{\mathbf{0}}$ & $\begin{array}{c}16 \text { a } \\
20 / 05 / 2016\end{array}$ & $\begin{array}{l}\text { Questionário diagnóstico } \\
\text { sobre dengue. }\end{array}$ & Questionário impresso. \\
\hline $2^{\circ}$ & $\begin{array}{c}23 \mathrm{a} \\
25 / 05 / 2016\end{array}$ & $\begin{array}{c}\text { Palestra "Combate à } \\
\text { Dengue". }\end{array}$ & $\begin{array}{l}\text { Palestra realizada pela equipe de educação da Vigilância } \\
\text { Ambiental/ Secretaria de Saúde DIVAL/SESDF. } \\
\text { Stand contendo amostras vivas e não vivas de todas as } \\
\text { fases de desenvolvimento do Aedes aegypti; maquete; } \\
\text { banners; cartazes; folders entregues aos alunos. }\end{array}$ \\
\hline $3^{\circ}$ & $\begin{array}{c}30 / 05 \text { a } \\
10 / 06 / 2016\end{array}$ & $\begin{array}{l}\text { Aulas teóricas de } \\
\text { Geografia. }\end{array}$ & $\begin{array}{l}\text { Realizadas pelo professor de geografia. } \\
\text { Data show, mapa da cidade, livro texto, mapa OMS, mapa } \\
\text { mundi, textos complementares. }\end{array}$ \\
\hline $4^{0}$ & $\begin{array}{c}13 / 06 \text { a } \\
24 / 06 / 2016\end{array}$ & $\begin{array}{l}\text { Aulas interdisciplinares } \\
\text { de } \\
\text { Ciências e Geografia. }\end{array}$ & $\begin{array}{l}\text { Realizadas pela comunidade investigativa. } \\
\text { Data show, textos impressos, cartazes e folders das } \\
\text { campanhas nacional e distrital de combate à dengue, } \\
\text { fotografias da quadra } 602 \text { do Recanto das Emas. }\end{array}$ \\
\hline $5^{0}$ & $\begin{array}{c}25 \text { a } \\
30 / 06 / 2016\end{array}$ & $\begin{array}{l}\text { Preparativos para a feira } \\
\text { de ciências Etapa Local. }\end{array}$ & $\begin{array}{l}\text { Participação da comunidade investigativa e de um grupo } \\
\text { de alunos selecionados. } \\
\text { Textos, livros, placas de MDF de } 5 \times 5 \mathrm{~cm} \text {, tintas, pincéis, } \\
\text { réguas, } 4 \text { placas de isopor, mapa da cidade, alfinetes, } \\
\text { cola, tesoura, cartolinas, papel A4, computador, } \\
\text { impressora. }\end{array}$ \\
\hline
\end{tabular}




\begin{tabular}{|c|c|c|l|}
\hline $\mathbf{6}^{\mathbf{0}}$ & $\mathbf{0 1 / 0 7 / 2 0 1 6}$ & $\begin{array}{c}\text { Exposição na Feira de } \\
\text { Ciências } \\
\text { Etapa Local. }\end{array}$ & $\begin{array}{l}\text { Exposição realizada pelos alunos participantes da feira. } \\
\text { Mesas, toalhas de mesa, cartazes, suco repelente, folder } \\
\text { informativo, mapas da OMS e do Recanto das Emas, jogo } \\
\text { da memória. }\end{array}$ \\
\hline $\mathbf{7}^{\mathbf{0}}$ & $\begin{array}{c}\mathbf{1 1} \text { e } \\
\mathbf{1 2 / 0 7 / 2 0 1 6}\end{array}$ & $\begin{array}{c}\text { Questionário avaliativo } \\
\text { do projeto. }\end{array}$ & $\begin{array}{l}\text { Questionário impresso aplicado aos alunos presentes na } \\
\text { data. } \\
\text { Universo: 78 alunos. }\end{array}$ \\
\hline $\mathbf{8}^{\mathbf{0}}$ & $\begin{array}{c}\text { Estudos e } \\
\mathbf{2 9 / 0 7 / 2 0 1 6}\end{array}$ & $\begin{array}{l}\text { planejamentos: luzes } \\
\text { para o encerramento } \\
\text { do projeto. }\end{array}$ & $\begin{array}{l}\text { Estudos e ensultas para a elaboração de atividade } \\
\text { referente à finalização do projeto, realizado pela } \\
\text { comunidade investigativa. } \\
\text { Confecção de power point para apresentação dos } \\
\text { resultados do projeto aos alunos. }\end{array}$ \\
\hline $\mathbf{9}^{\mathbf{0}}$ & $\mathbf{0 6 / 0 9 / 2 0 1 6}$ & $\begin{array}{c}\text { Exposição Circuito de } \\
\text { ciências regional }\end{array}$ & $\begin{array}{l}\text { Exposição do projeto para a comunidade escolar do } \\
\text { Recanto das Emas nos turnos matutino, vespertino e } \\
\text { noturno. }\end{array}$ \\
\hline $\mathbf{1 0}^{\mathbf{0}}$ & $\mathbf{2 8 / 0 9 / 2 0 1 6}$ & $\begin{array}{c}\text { Mutirão socioambiental. } \\
\text { Organização das cadeiras e carteiras depredadas } \\
\text { acumuladas em um espaço a céu aberto no interior da } \\
\text { escola. }\end{array}$ \\
\hline
\end{tabular}

Quadro 3: Cronograma das atividades desenvolvidas no projeto.

Fonte: elaboração própria.

À medida que os ciclos ocorreram, quatro registros auto-reflexivos foram escritos pelo professor regente em tempos espaçados, sob a perspectiva de promover momentos para a auto-reflexão profissional, permitindo que a prática educacional, a compreensão dessa prática e de situações nas quais ele pratica configurem-se como objeto da pesquisa-ação educativa (Carr e Kemmis, 1986; Adelman, 1993).

Acrescidos aos registros auto-reflexivos do professor regente, as concepções e conhecimentos discentes coletados por meio de dois questionários foram tratados conforme a metodologia da análise de conteúdo (Bardin, 2011). No primeiro momento, a pré-análise, foi realizada uma leitura flutuante dos dados e a seleção dos elementos correlacionados aos objetivos de pesquisa e utilizados na fase subsequente, exploração do material.

Parte dos dados selecionados na pré-análise foram inseridos no sítio Tagul.com que constituiu uma nuvem de palavras. Partiu-se da nuvem obtida para a elaboração das categorias de análise de conteúdo. Para estas averiguações, a contagem de palavras foi utilizada em dois momentos, e no restante fez-se interpretações e inferências, o que permite um diálogo entre dados quantitativos e qualitativos, mesmo considerando que 
as inferências nem sempre se baseiam em indicadores quantitativos (Bardin, 2011, p. $133)$.

\section{RESULTADOS E DISCUSSÕES}

Os resultados e discussões serão apresentados seguindo a ordem cronológica da realização dos dez ciclos, os quais unidos constituíram a espiral cíclica da presente pesquisa-ação em educação ambiental, somados pelas análises dos registros auto reflexivos do professor regente e as inferências do autor.

\subsubsection{Primeiro ciclo - Questionário diagnóstico.}

A partir da escolha da temática do projeto, a comunidade se reuniu para fazer uma leitura da proposta buscando compreender melhor a hipótese colocada e conferir no Currículo em Movimento da Educação Básica (SEDF) os conteúdos que poderiam ser trabalhados, envolvendo as disciplinas de geografia e ciências naturais.

A concepção de que ninguém ignora ou sabe tudo, todos nós sabemos alguma coisa (FREIRE, 1999, p.47) orientou a primeira ação planejada, que deveria antes de qualquer intervenção, conferir o que os alunos já sabiam sobre a temática, resultando na aplicação de um questionário diagnóstico (anexo 4).

$\mathrm{Na}$ oportunidade, foi colocada a imagem de um cartaz da campanha nacional de combate à dengue como elemento provocador, na tentativa de revelar as concepções dos alunos sobre a mensagem transmitida.

Os alunos antes de participarem da atividade, foram informados sobre o projeto e a parceria constituída entre o professor regente/pesquisadora, informando-os do objetivo geral do projeto bem como o objetivo da primeira ação. Desta maneira, a comunidade iniciou suas atividades estabelecendo uma postura transparente com relação aos dados, interpretações e apontamentos da pesquisa conforme Elliot (1978) outrora os considerou relevante para uma pesquisa-ação.

O objetivo traçado pela comunidade investigativa e apresentado aos alunos antes do início da ação foi:

Fazer um diagnóstico primário sobre os conhecimentos dos alunos dos oitavos anos do CEF 602 com relação à temática - Dengue, transmissão e combate - que será utilizado 
como base para os planejamentos das aulas de geografia do segundo bimestre do ano letivo 2016.

O professor regente aplicou o questionário e percebeu que os alunos ficaram com algumas dúvidas com relação à interpretação das perguntas, levando-o a explicar as questões antes do preenchimento. Os alunos inicialmente não compreenderam a relação da temática - combate à dengue - com a disciplina de geografia, em suas falas significativas eles revelaram o entendimento de que a pertinência da temática era exclusiva às aulas de ciências naturais.

Esse fator revela uma familiaridade e possível condicionamento às metodologias que compartimentam o saber em disciplinas curriculares, reproduzindo o tratamento cartesiano que fragmentou os objetos da ciência, e que possivelmente foi legado aos alunos por meio do sistema educacional no qual eles e seus professores se inserem.

Nas reflexões dos investigadores, o não relacionamento da temática do projeto aos conteúdos de geografia foi entendido como uma oportunidade de proporcionar aos alunos práticas contextualizadas e interdisciplinares, agregando em momentos possíveis questões sociais, econômicas, comportamentais e políticas para estimular um olhar multidisciplinar importante às temáticas de EA.

A atividade da primeira espiral foi realizada com um universo de 84 alunos e as análises das tabulações revelaram a compreensão de que o mosquito fêmea transmite não o vírus, mas a doença para o homem. Nenhum aluno apresentou respostas completas sobre o ciclo da dengue, apontando que esta seria a primeira lacuna de conhecimento científico que deveria ser trabalhada.

Com relação à influência dos fatores geográficos e a doença, a maioria dos alunos não conseguiu fazer a relação. Excetuando-se dois questionários, nos 82 restantes não foi verificado qualquer referência a um ou mais fatores geográficos, houve sim uma confusão com erradicação do lixo, porém sem avanços. Esperava-se nessa questão que ocorressem apontamentos quanto ao clima, vegetação, incidência da doença nos países localizados na faixa equatorial, uma vez que esses temas estão presentes no currículo do sétimo e oitavo ano.

As lacunas epistemológicas sobre o ciclo da doença e a correlação com fatores geográficos apontaram nas reflexões da comunidade investigativa que estes dois pontos deveriam ser trabalhados nos ciclos subsequentes. 
Em 96\% do universo participante, a compreensão da relação entre o mosquito e a água está correta, porém, a única forma de combate à dengue registrada em 100\% dos escritos foi a erradicação do vetor evitando a água parada pelo acúmulo de lixo. Este índice demonstra uma única concepção de se combater a dengue, que corrobora as informações contidas e divulgadas pelas campanhas governamentais brasileiras.

Indagados sobre a localização de possíveis focos de dengue próximos à quadra 602 do Recanto das Emas, os alunos apontaram locais atrás da escola com acúmulo de lixo, foi dito que na quadra de esportes ao lado da escola as ferragens da cerca estão velhas e acumulam muita água. Esse questionamento surgiu com o objetivo de estimular o diagnóstico participativo e o desenvolvimento de ações positivas comentados por Saito (2006) favoráveis a educação ambiental.

Para o autor

o diagnóstico dos problemas socioambientais pode ser feito participativamente, favorecendo o engajamento das comunidades na busca de soluções para os problemas, e propiciando maior adesão e participação nas ações positivas, tanto governamentais como da sociedade civil (Saito, 2006, p. 5)

Os últimos dados do questionário revelaram que para 77\% dos participantes, a fonte dos conhecimentos adquiridos sobre a dengue provém de cartazes em órgãos públicos (posto de saúde, escola, etc.), comerciais de televisão, rádio e telejornais. Considerando que estes são importantes veículos utilizados pelas campanhas governamentais, pode-se atribuir o maior peso dos conhecimentos trazidos pelos alunos às ideologias das campanhas. Em segundo lugar, a origem do conhecimento foi adquirida nas escolas durante as aulas.

Mesmo absorvendo diariamente informações veiculadas pelos materiais de campanha, os alunos revelaram crédito parcial sobre sua eficácia. Para 33 pessoas as campanhas são eficazes, outros 33 não as consideram eficazes, 12 respostas afirmaram que a eficácia é parcial e 6 questionários deixaram a questão em branco. A quantificação dos conhecimentos demonstra uma confiança enfraquecida sobre a eficácia das campanhas.

Uma das possíveis justificativas para o descrédito dos participantes é a constatação dos avanços nos números da doença divulgados pela mídia. Conforme os 
boletins epidemiológicos do Ministério da Saúde, na semana epidemiológica 4/2016 haviam no país 116.966 casos prováveis de pessoas com dengue, na semana 27/2016 esse número subiu para 1.399.480 (tabela 1).

Tabela 1: Aumento de casos notificados e prováveis de dengue no Brasil.

\begin{tabular}{ccc}
\hline $\begin{array}{c}\text { Semana Epidemiológica (SE) } \\
\text { /Ano }\end{array}$ & $\begin{array}{c}\text { Número de casos } \\
\text { notificados }\end{array}$ & $\begin{array}{c}\text { Número de casos } \\
\text { prováveis }\end{array}$ \\
\hline $\mathbf{2 , 2 0 1 6}$ & 41.264 & - \\
$\mathbf{3 , 2 0 1 6}$ & 73.872 & - \\
\hline $\mathbf{4 , 2 0 1 6}$ & - & 116.966 \\
$\mathbf{2 7 , 2 0 1 6}$ & - & 1.399 .480 \\
\hline
\end{tabular}

Fonte: Secretaria de Vigilância em Saúde, Ministério da Saúde.

A décima e última pergunta do questionário verificou as opiniões dos participantes sobre o cartaz a seguir:

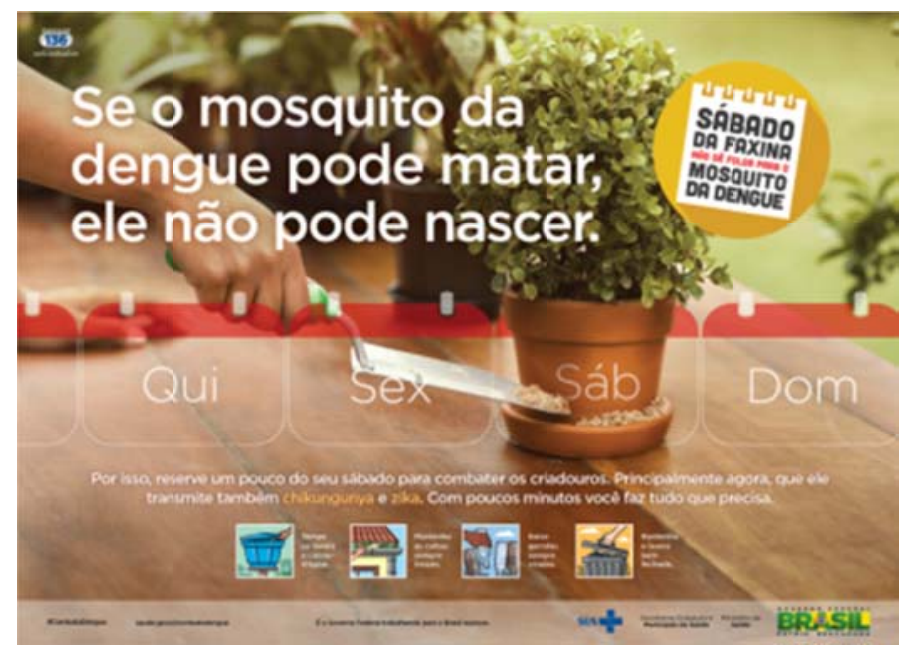

Figura 7: Cartaz de campanha publicitária do Ministério da Saúde.

Fonte:http://www.blog.saude.gov.br/combate-ao-aedes/50390-combate-ao-mosquito-aledes-e-diagnosticode-microcefalia.html. Acesso em 29/04/2016.

As falas dos alunos concordaram de forma unânime com a mensagem apresentada no cartaz. Todas as respostas registradas foram lançadas no sítio Tagul que contabilizou as palavras selecionadas gerando a nuvem observada na figura 8 . 


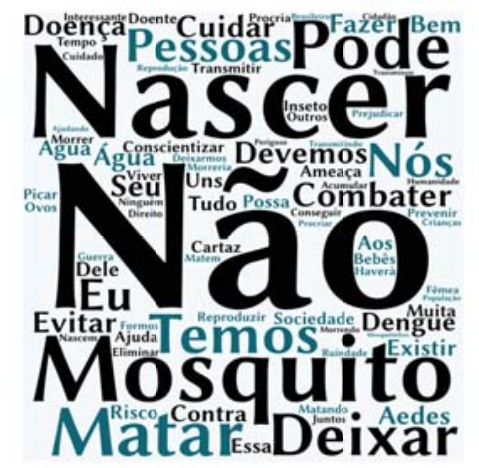

Figura 8: Nuvem de palavras da décima questão do questionário diagnóstico.

Fonte: elaboração própria a partir do sítio Tagul.

Considerando que a nuvem de palavras representa graficamente o tamanho das mesmas de acordo como o número de repetições, as palavras mais frequentes foram "não", "nascer", "pode" e "mosquito", o que constituiu a primeira categoria de análise: O MOSQUITO NÃO PODE NASCER.

Dos registros que revelaram a categoria foram elencadas cinco subcategorias que a justificam segundo as concepções dos alunos, e sua frequência apresientada na tabela 2. Das subcategorias encontradas, a justificativa de que o mosquito não pode nascer porque ele pode matar foi a mais frequente, exatamente como a mensagem do cartaz preconizou.

Tabela 2: Frequência das justificativas ocorridas para a categoria "O mosquito não pode nascer".

\begin{tabular}{|c|c|c|}
\hline Categoria & $\begin{array}{c}\text { Subcategorias de justificativa } \\
\text { O mosquito não pode nascer por que/para... }\end{array}$ & Frequência \\
\hline \multirow{7}{*}{$\begin{array}{l}\text { O mosquito não pode } \\
\text { nascer. }\end{array}$} & 1. Transmite doença. & 8 \\
\hline & 2. Para não matar. & 20 \\
\hline & 3. É uma ameaça par a sociedade. & 6 \\
\hline & 4. Põe em risco nossas crianças e bebês. & 1 \\
\hline & 5. O mosquito é um mal. & 2 \\
\hline & 6. Não justificaram a categoria. & 47 \\
\hline & TOTAL & 84 \\
\hline
\end{tabular}

Fonte: Elaboração própria.

Os dados inferem que os alunos assimilaram os conhecimentos tais como foram colocados, não conseguindo desvelar a profundidade da ideologia construída, que 
alimenta a concepção de que o mosquito não tem o direito de existir por transmitir doença para os humanos.

Considera-se que a abordagem das campanhas oficiais brasileiras está conceitualmente incorreta, uma vez que adota um paradigma antropocêntrico das relações estabelecidas entre o ser humano e os elementos bióticos ecossistêmicos. A concepção assim como está, pode induzir a ideologia de que qualquer espécie viva do planeta que ameace a vida humana não tem o direito de existência, o que contrapõe os preceitos da ecologia e sustentabilidade no qual, dentre outros, os seres humanos devem conviver de forma equilibrada junto a outros seres vivos.

Vale lembrar que o cerne da crítica discorrida não se ancora na defesa da vertente biocêntrica, presente no ecologismo radical mas na falta de conhecimento sobre o ciclo à população e formas de prevenção. Na interpretação de Barbosa e Drummond este mesmo ecologismo apresentou a visão de direitos da natureza e, para a comunidade biocêntrica, não existem elementos englobadores nem hierarquias, mas apenas a valorização de todo e qualquer ciclo vital, independente do seu valor estético, utilitário ou estratégico para os seres humanos (Barbosa e Drummond, 1994, p. 266).

O paradigma antropocêntrico das campanhas oficiais brasileiras, embora considere a gravidade da epidemia, vem adotando um tom alarmista análogo ao que Fretwell (2009) considera por ciência do medo. Para o autor, medo e emoção são usados para motivar a ação, além disso, evidências mostram que quanto mais repetitiva a história, maior o medo e as pessoas ficam mais propensas a responder. Esta é a ciência do medo.

Observa-se que tanto nas frases dos cartazes como nas informações contidas é imperativo que o vetor é o único e grande mal a ser combatido, pois, segundo os mesmos, pode matar até bebês. $\mathrm{O}$ tom maléfico dado ao mosquito estimula emoções e medo, o que orienta não só a ação de combatê-lo, mas legitima a ideologia do mosquito não ter o direito de existência. $\mathrm{O}$ resultado disto é que a ciência do medo ensina às pessoas o que pensar e não como pensar, como um meio para defender um resultado desejado ao invés de motivar a resolução criativa de problemas (Fretwell, 2009, p. 9).

A situação se agrava na medida em que o peso da culpa pela epidemia dada ao mosquito vetor poderia legitimar, ou desviar a atenção das populações, às ações de 
controle da doença adotadas pelo Governo Federal e Ministério da Saúde (MS). A exemplo disto tem-se o uso do fumacê que dispersa o inseticida organofosforado malathion no ambiente e tem ação carcinógena e neurotóxica conhecida.

Um outro exemplo foi denunciado pelo grupo de médicos argentinos intitulados "Médicos dos povos pulverizados", no qual relatam que os casos de bebês microcéfalos registrados no Brasil não decorrem das transmissões do Zika vírus pelo inseto vetor e sim, trata-se de uma situação de envenenamento (Bayer, 2016, p. 8).

A afirmação se ancora no fato de que a introdução em 2014 de pesticida à base de Pyriproxyfen na água potável das regiões mais atingidas é a causa mais provável de microcefalia, na medida em que as epidemias anteriores causadas por zika vírus não causaram alterações congênitas em recém-nascidos. Eles também observam que em outros países, como a Colômbia não há registros de microcefalia ainda que sejam abundantes os casos de contaminação por Zika vírus (Bayer, 2016, p.8).

O larvicida, fabricado pela Sumimoto Chemical - subsidiária da Monsanto no Brasil, foi adotado por um programa estatal destinado ao controle das populações do vetor. As críticas do grupo incidem sobre a associação quase instantânea dada pelo MS ao Zika vírus como causador de microcefalia no Brasil, e a não correlação, ou pelo menos um ato investigativo aprofundado sobre a adição do pyriproxyfen à água potável das comunidades afetadas.

Uma vez que adicionado à água potável inseticidas, larvicidas, ou quaisquer que sejam os elementos químicos, essa torna-se despotabilizada, violando o direito humano à água potável conferido em assembléia geral da ONU.

A Associação Brasileira de Saúde Coletiva (Abrasco) também se manifestou sobre a questão emitindo uma nota técnica cujo teor discorreu sobre a microcefalia e doenças vetoriais relacionadas ao Aedes aegypti e os perigos das abordagens com larvicidas e nebulizações químicas - fumacê.

Dentre os fatos apontados pela nota técnica, nos contextos que envolveram o aparecimento dos casos de microcefalia, a utilização continuada de larvicidas químicos na água de beber das famílias ocorria há mais de 40 anos sem, contudo, implicar na redução do número de casos de doenças provocadas por arbovírus ${ }^{17}$. Ademais, a

\footnotetext{
${ }^{17}$ Vírus essencialmente transmitidos por artrópodes (Storer et al, 2000).
} 
introdução em 2014 na água das populações e vias públicas do larvicida o Pyriproxyfen que tem ação teratogênica é questão de extrema relevância que não foi considerada pelo MS.

Outro ponto pertinente da nota técnica problematiza a forma de combate do MS, que preconiza o combate exclusivo ao vetor, em repetição ao que vem sendo adotado há mais de 40 anos sem sucesso.

A questão tem potencial de se correlacionar às questões outrora alertadas ao mundo por Rachel Carson (1962): o envenenamento das populações e do meio ambiente por meio do uso de substâncias químicas. A diferença da situação contemporânea para as denúncias dos anos 60, talvez, resida no público envenenado: as populações mais pobres.

Os governos, que por sua vez, deveriam proteger essas pessoas dado seu status de vulnerablidade, despotabiliza sua água com um larvicida teratogênico e dispersa mais veneno no ambiente por meio dos carros de fumacê. Exige-se destacar que no ano de 2016 o presidente Michel Temer sancionou a lei 13.301 que dentre outras medidas, permite a "incorporação de mecanismos de controle vetorial por meio de dispersão por aeronaves mediante aprovação das autoridades sanitárias e da comprovação científica da eficácia da medida” (BRASIL, 2016).

$\mathrm{Na}$ época, variadas instituições como a Fiocruz, Ministério da Saúde, Abrasco, Consea, Conasems, Conass, etc., se posicionaram contra a medida, ancorados em variados exemplos análogos que não surtiram efeito, ainda assim o texto da lei foi aprovado justamente no momento em que o mercado apontava uma queda de $20 \%$ nas vendas de agrotóxicos.

Conforme o grupo de Médicos argentinos, os governos do Mercosul adotam medidas criminosas e inúteis, em uma manobra política para simular que as ações estão sendo tomadas (Bayer, 2016, p. 8). Possivelmente, o curso contra-a-corrente das medidas adotadas pelo governo brasileiro, independente dos fatos visíveis, objetiva interesses econômicos, na medida em que os pactos de combate exclusivo ao vetor implicam compras de produtos químicos que favorecem o empresariado e as grandes corporações.

Para a Abrasco (Nota Técnica, fev. 2016), trata-se de um negócio lucrativo de abrangência mundial e que, mesmo com a evidência dos riscos causados por organofosforados e piretróides, está sendo apoiado por governos e agências de saúde, 
como a OMS. Em outras palavras, a ciência do medo obscurece as questões que envolvem toda a situação epidêmica dos arbovírus e induz a sociedade a incorporar as medidas "preventivas" oficiais.

A superação do problema não é algo fácil ou instantâneo, embora o envolvimento de vidas humanas, a superação da situação indistintamente perpassa o campo da educação na sua oportunidade de problematizar e refletir a realidade unida ao saber e transformá-lo em ação, para Freire

somente quando os oprimidos descobrem, nitidamente, o opressor, e se engjam na luta organizada por sua libertação, começam a crer em sí mesmos, superando, assim, sua "convivência" com o regime opressor. Se esta descoberta não pode ser feita em nível puramente intelectual, mas da ação, o que nos parece fundamental é que esta não se cinja a mero ativismo, mas esteja associada a sério empenho de reflexão, para que seja práxis (Freire, 2011, p. 72).

A figura 9 referente a um cartaz da campanha de 2016 no Distrito Federal, corrobora a concepção de que o mosquito não tem o direito de existir:

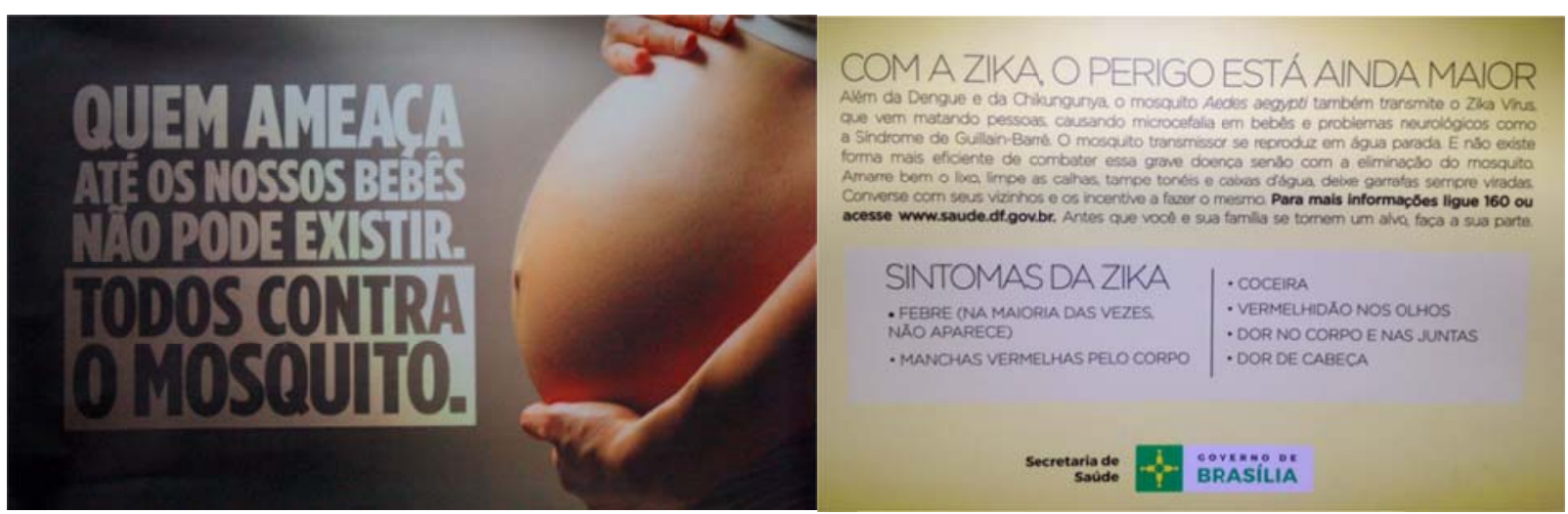

Figura 9: Cartaz de campanha publicitária da Secretaria Estado de Saúde do Governo do Distrito Federal. Fonte: SESDF campanha 2016.

As opiniões expressas pelos alunos colocadas na tabela 2 demonstram o potencial que as campanhas têm em enraizar concepções, corretas ou incorretas, na consciência das pessoas. Na justificativa 4 apontada por um aluno na tabela 2 percebese que, antes mesmo da comunidade analisar o cartaz do GDF em sala de aula com os alunos, o conteúdo da fala se aproxima da frase no cartaz. No caso do combate à dengue, o estigma de que o mosquito é o único vilão já está incorporado nas concepções 
dos participantes da pesquisa e, possivelmente, pela sociedade, que por sua vez pouco menciona o agente viral.

Os discursos proferidos pelas campanhas de combate à dengue no Brasil têm criado uma ideologia da não existência do mosquito, ou seja, a utopia de levar a espécie à extinção, mesmo sabendo que não existe consenso na comunidade científica sobre a questão, até mesmo por considerar o papel ecológico desempenhado pelos gêneros de mosquitos, como por exemplo, a sua participação nas cadeias tróficas (Storer, 2000, p. 286).

O cartaz da campanha no Distrito Federal (SESDF, 2016) traz em seu texto a informação "E não existe forma mais eficiente de combater essa grave doença senão com a eliminação do mosquito", o que conduz à uma consciência coletiva do não direito de existência de uma espécie viva do planeta. Além do exposto, a frase desconsidera outras atitudes preventivas.

Sabe-se que uma das maneiras adotadas em Cuba para o controle da epidemia consistiu em cuidados a serem tomados pelos doentes, na tentativa de isolá-los dos mosquitos durante a fase infectiva ${ }^{18}$. Essa ação preventiva contribuiu para que o país alcançasse êxito no controle da doença, fator que levou a OMS a congratular a vigilância sanitária cubana (Bazin, 2008).

No bojo trata-se de interromper o ciclo da doença na fase homem contaminado vetor, medida preventiva cabível à transmissão dos arbovírus ${ }^{19}$ cujo Aedes aegypti é o vetor. Além do exposto, somam-se às medidas de combate à epidemia a questão da falta de saneamento básico vivida pelas populações mais pobres do Brasil, na medida em que os maiores índices de pessoas contaminadas ocorre nestes grupos.

Johansen (2014) verificou que a dengue não é uma doença democrática que atinge igualmente a todos os grupos sociais, como prega o senso comum. Seus estudos demonstraram que a doença está mais associada aos grupos de estratos socioeconômicos menos favorecidos, especialmente os de baixa renda e de negros.

\footnotetext{
${ }^{18}$ A fase infectiva corresponde ao período de tempo em que o vírus causador da dengue encontra-se multiplicado em seu organismo incluindo suas glândulas salivares. Neste momento o mosquito fêmea torna-se infectivo e, somente a partir deste momento, poderá transmitir o vírus a outra pessoa. (http://www.ioc.fiocruz.br/dengue/textos/aedesvetoredoenca.html).

${ }^{19}$ Grupo de vírus transmitidos essencialmente por artrópodes (Trabulsi et al, 2002).
} 
É importante afirmar que o combate ao vetor é uma estratégia relevante na busca do controle da epidemia, não se pode dispensar essa concepção, porém ela sozinha não tem sido suficiente conforme os dados informados nos variados boletins epidemiológicos divulgados pelo Ministério da Saúde (MS, 2016), que explicitam um aumento explosivo da densidade dos casos prováveis e notificados conforme tabela 1.

As reflexões realizadas na fase reconstrutiva do primeiro ciclo da pesquisa indicaram que o próximo ciclo deveria abordar conhecimentos gerais sobre a dengue, como sua origem e formas de prevenção. Para verificar a hipótese do projeto iniciado e expor conhecimentos sobre a dengue aos alunos, a comunidade convidou o setor de educação da Vigilância Ambiental da SESDF (DIVAL/SESDF) para realizar a ação do segundo ciclo de pesquisa: uma palestra sobre o tema.

\subsubsection{Segundo ciclo - Palestra sobre combate à dengue.}

Diante da necessidade de aprofundar os estudos sobre o combate à dengue na escola, a comunidade investigativa refletiu que a realização de uma palestra conferida pela equipe da DIVAL aos alunos enriqueceria as discussões do projeto devido seu conhecimento da temática, atualização dos dados, exposição de materiais.

O objetivo do ciclo traçado pela comunidade investigativa no planejamento do ciclo foi: difundir conhecimentos atualizados sobre a dengue, sua origem e processo histórico no Brasil e no mundo, suas formas de prevenção e exposição de stand com materiais afins para apreciação dos alunos e complementação dos estudos.

A ação foi realizada nos dias 24 e 25 de maio e teve a participação total de 96 alunos. A equipe dedicou seu tempo de exposição descrevendo as características e diferenças das três doenças cujo Aedes é vetor (Dengue, Zika e Chikungunya); foi revelado o avanço no número de casos de pessoas com dengue no DF, comparando com os índices do ano anterior o que causou alarme entre os alunos.

Adiante, fez-se um histórico relatando a origem da dengue e sua chegada ao Brasil. Também foi explicado o ciclo de desenvolvimento do mosquito Aedes aegypti, com o apoio de banners, mas o foco principal foram os meios de prevenção.

Uma vez que a equipe palestrante pertence à Secretaria de Estado de Saúde do Distrito Federal, os conhecimentos passados foram baseadas nas diretrizes e metas traçadas pelo programa de combate à dengue vinculado ao MS, portanto, um programa 
de combate ao vetor. Desta forma, os meios de prevenção da doença divulgados foram evitar o acúmulo de água parada, somente.

Uma professora da escola que participou da palestra junto com seus alunos fez alguns questionamentos à palestrante com relação à origem da contaminação do mosquito e, a comunidade investigativa observou que a mesma não sabia que os mosquitos, exceto na transmissão transovariana, nascem descontaminados. Ao final da explicação, a mesma professora proferiu a frase - então você está me dizendo que o mosquito não nasce contaminado, é isso mesmo? - dada a revelação a equipe palestrante não discutiu, só confirmou a constatação.

Ao longo da explanação, foi perguntado aos alunos se algum deles já havia contraído dengue. No primeiro dia de palestra um aluno se manifestou, e no segundo dia três alunos relataram que já sofreram com a doença. A fase final da explanação se deu com audiência ao filme "Todos contra a dengue" produzido pelo SESI. A ideia central do filme é orientar sobre como não acumular água parada e os tratamentos possíveis para os infectados.

Finalizada a palestra (figura 13), os alunos observaram um estande que foi montado pela equipe contendo maquete, banners (com informes sobre transmissão, ciclo do mosquito e prevenção da dengue), amostras das quatro fases de vida do mosquito (ovo, pupa, larva e mosquito) e um criadouro de laboratório contendo amostras vivas de todos os estágios de vida do mosquito. Houve grande interesse com relação aos materiais expostos no estande e na oportunidade foram entregues folders das campanhas do GDF de 2016. 
A comunidade refletiu que a palestra atingiu parcialmente o objetivo proposto, visto que não contemplou as formas de prevenção que interrompem o ciclo entre homem contaminado/vetor. Os alunos manifestaram interesse pela temática, uma vez que eles têm presenciado pessoas acometidas pela doença, além das possibilidades de acometimento da dengue para qualquer um dos participantes que estavam vivenciando o projeto. Para a comunidade investigativa os estandes complementaram e enriqueceram os temas abordados além do fortalecimento da hipótese do projeto.
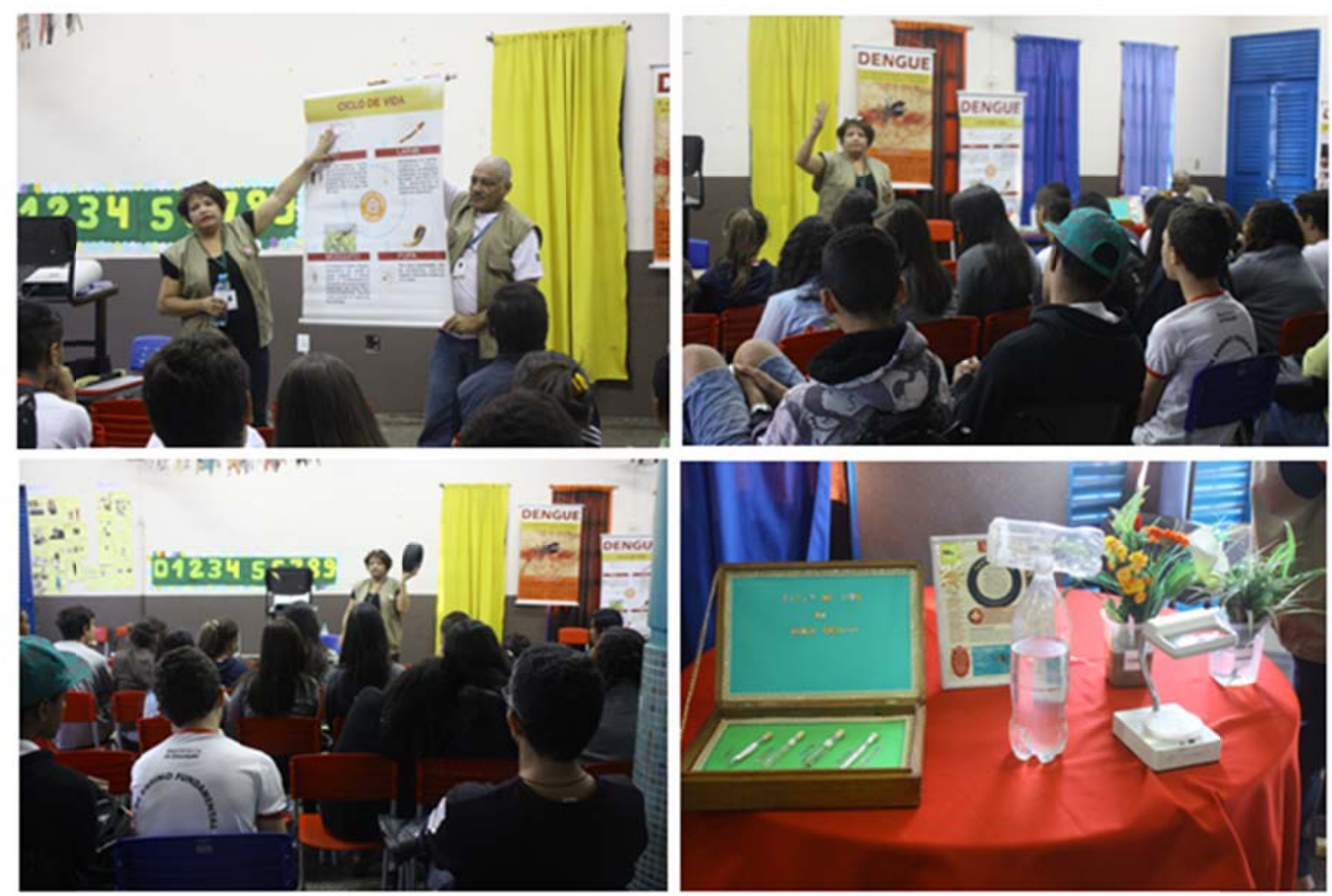

Figura 10: Palestra e stand realizados pela DIVAL/SESDF. Fonte: Lívia Miranda de Oliveira

\subsubsection{Terceiro ciclo - Aulas de Geografia}

Os ciclos anteriores revelaram à comunidade que seria necessário explicar para os alunos os fatores geográficos que influenciam a distribuição dos casos de dengue no mundo e no Brasil. No planejamento inicial, a ação delimitada iria ocorrer utilizando os recursos oferecidos pelo software Google Earth e a internet, que juntos contribuiriam para: i) o desenvolvimento da noção espacial e a representação cartográfica; ii) a comparação de diferentes tipos de superfície terrestre envolvendo análises de mapas, 
fotos de satélite, imagens aéreas e tridimensionais; iii) observação de diferentes escalas do espaço geográfico; iv) localização do Continente Americano em imagens de satélite e correlacionar os conhecimentos visualizadas com os fatores que influenciam o clima, altitude, as formas de vegetação e a existência do mosquito Aedes aegypti no Continente Americano.

A realização do planejamento encontrou um obstáculo a ser enfrentado: as relações de poder entre professores e a gestão do CEF 602 do Recanto das Emas. Na história humana sempre existiram, independente da natureza, relações de poder. Para Friedberg é preciso que existam pelo menos duas pessoas e uma estrutura de ação coletiva para que o poder se manifeste. Pode-se afirmar que toda estrutura de ação coletiva, por ser uma construção humana, envolve um sistema de poder. Só quando os atores têm um mínimo de autonomia é que se pode falar de relações de poder entre eles. E essa autonomia mede-se pela sua capacidade não teórica, mas real, de não fazer o que se espera deles, ou de fazer de forma diferente. (Friedberg 1993, p.255).

Antes do planejamento ser delineado, a comunidade em suas reflexões já havia manifestado o interesse de realizar um ciclo da espiral no laboratório de informática (LI) da escola mesmo sabendo que este não era utilizado pelos professores.

O planejamento da ação contando com o laboratório foi escrito, pois sabia-se que havia computadores no espaço e que as escolas públicas do DF recebem verba que pode ser destinada para a manutenção de micros e conexão à rede.

O passo seguinte foi apresentar à gestora da escola o planejamento construído, para verificar a possibilidade de sua execução. Embora a mesma tenha comentado sobre a relevância de metodologias que envolvam os meios digitais, esta informou à comunidade que o espaço não estava disponível, ou seja, vivenciava-se no momento o não fazer e/ou fazer diferente comentado por Friedberg (1993).

A comunidade refletiu que a situação deveria ser investigada na instância superior que coordena as escolas da cidade, a CRE Recanto das Emas, que dentre seus setores conta com o Núcleo de Tecnologia (NTE), responsável por formação continuada de professores em tecnologias da informação e manutenção dos laboratórios de informática das escolas públicas da cidade. 
O movimento de buscar informações em outros setores da SEDF, no sentido de complementar e em alguns casos confirmar o que as equipes gestoras escolares determinam aos professores é uma ação proveitosa, passível de fortalecimento docente. Em primeiro lugar por permitir o conhecimento e contato com núcleos de coordenação pertencentes à hierarquia do serviço público educativo, e por consequência, a dimensão organizacional da SEDF. Desta forma o conhecimento instrumentaliza o professor para o seu repensar e refazer cotidiano promovendo empoderamento (Saito, 2006, p.28).

Segundo por consultar a veracidade das informações dadas aos docentes alimentando a práxis investigativa, na transição para um perfil de professorpesquisador, e finalmente, pelo potencial de desvelar relações de poder sobre as ações praticadas na escola buscando transformar situações educativas, em um compromisso concreto para a melhoria da educação (Carr e Kemmis 1986, p. 158).

O curso da pesquisa-ação conduziu a comunidade investigativa a levar a situação da impossibilidade de utilização do laboratório de informática da escola - ao núcleo de tecnologia (NTE) da CRE Recanto das Emas.

$\mathrm{Na}$ oportunidade a comunidade foi recebida pelos coordenadores do NTE e foi verificado que: o espaço poderia e deveria estar sendo usado pelo corpo docente; o patrimônio da escola em questão declara a existência de mais de 10 computadores no LI além de mobiliário adequado; a não existência de um profissional exclusivo para o laboratório não impediria que os computadores fossem utilizados uma vez que a manutenção das máquinas pode ser dada pelo NTE assim que for solicitado.

O movimento realizado pela comunidade levou os coordenadores do NTE a se reunirem com a direção da escola que manteve o posicionamento da não liberação do espaço, sob a condição de que este só seria disponibilizado no momento em que a escola pudesse contar com um profissional exclusivo para atuar no laboratório de informática.

O curso da pesquisa-ação educacional iniciada defrontou duas instâncias superiores na hierarquia escolar, o que foi refletido como um movimento importante para o empoderamento docente, ação consciente nunca atingida e/ou buscada pela práxis do professor regente.

Desvelado o conflito, o núcleo responsável informou que a condição imposta pela direção da escola era inconsistente e impeditiva do direito de uso de material público por professores e alunos. A situação foi registrada e encaminhada a uma coordenação 
central da SEDF responsável pelos laboratórios de informática da rede pública. A comunidade não obteve resposta sobre a solicitação.

Foi impossível para a comunidade investigativa não refletir sobre a problemática existente no cotidiano educacional, que dicotomiza as frentes de poder da gestão e docência, em embates deletérios geradores de divisões nesses segmentos que, em oposição comportamental a isto, necessitam se unir e fortalecer pois a intencionalidade de sua práxis deveria ser sempre em favor da educação.

Nas reflexões subsequentes, o exercício de conhecer os vários segmentos que compuseram o conflito ampliaram o olhar da CI para o enfrentamento de situações análogas, indicando que em certos casos é preciso ultrapassar a sala da direção e os muros da escola para buscar conhecer a situação em todas as instâncias diretamente envolvidas na busca de mudanças possíveis e necessárias.

Assim, a práxis da comunidade investigativa começa a se remodelar, incorporando visão mais sistêmica e crítica das situações vividas no contexto educacional. Era imperativo verificar se um novo olhar é o suficiente para a transformação das realidades.

Mesmo o laboratório não tendo sido liberado no momento solicitado, o movimento da investigação conseguiu encaminhar a situação para instâncias superiores competentes o que possivelmente exigirá da direção da escola justificativas outras para o impedimento.

O cronograma não se estagnou, não era dada à comunidade a posição de esperar a liberação do laboratório, o que resultou no replanejamento do ciclo.

O objetivo delimitado para o ciclo foi: desenvolver a noção espacial $e$ a representação cartográfica; comparar diferentes tipos de representação da superfície terrestre: mapas, fotos de satélite, imagens aéreas e tridimensionais; localizar o Continente Americano em mapas disponíveis na escola; analisar e localizar no mapa do Recanto das Emas os casos de dengue informados pela Vigilância Ambiental do GDF.

Observou-se que as aulas ocorreram de forma organizada e participativa, porém o foco e concentração dos alunos se dividiram devido à realização de gincana e os preparativos para a festa junina que ocorreu no dia 11/06/2016, ou seja, exatamente nas semanas das aulas. 
Dentre as atividades realizadas, a análise do mapa da Organização Mundial da Saúde (figura 14) sobre os registros de dengue no mundo foi o ponto de partida para introduzir os fatores geográficos inerentes à disseminação da doença no mundo. A atividade final foi a análise do mapa da cidade, retirado do sítio da administração local, onde os alunos deveriam primeiro localizar a sua moradia, a escola, o terminal rodoviário e a vila olímpica da cidade. Muitos relataram que nunca tinham observado o mapa da cidade onde vivem e tiveram dificuldade de localizar os pontos solicitados pelos professores.

Dentre outros elementos trabalhados na atividade, a solicitação final foi para que marcassem com alfinetes todos os casos de dengue ocorridos na cidade entre os meses de janeiro a junho de 2016 segundo a lista fornecida à comunidade investigativa pela vigilância ambiental do DF.

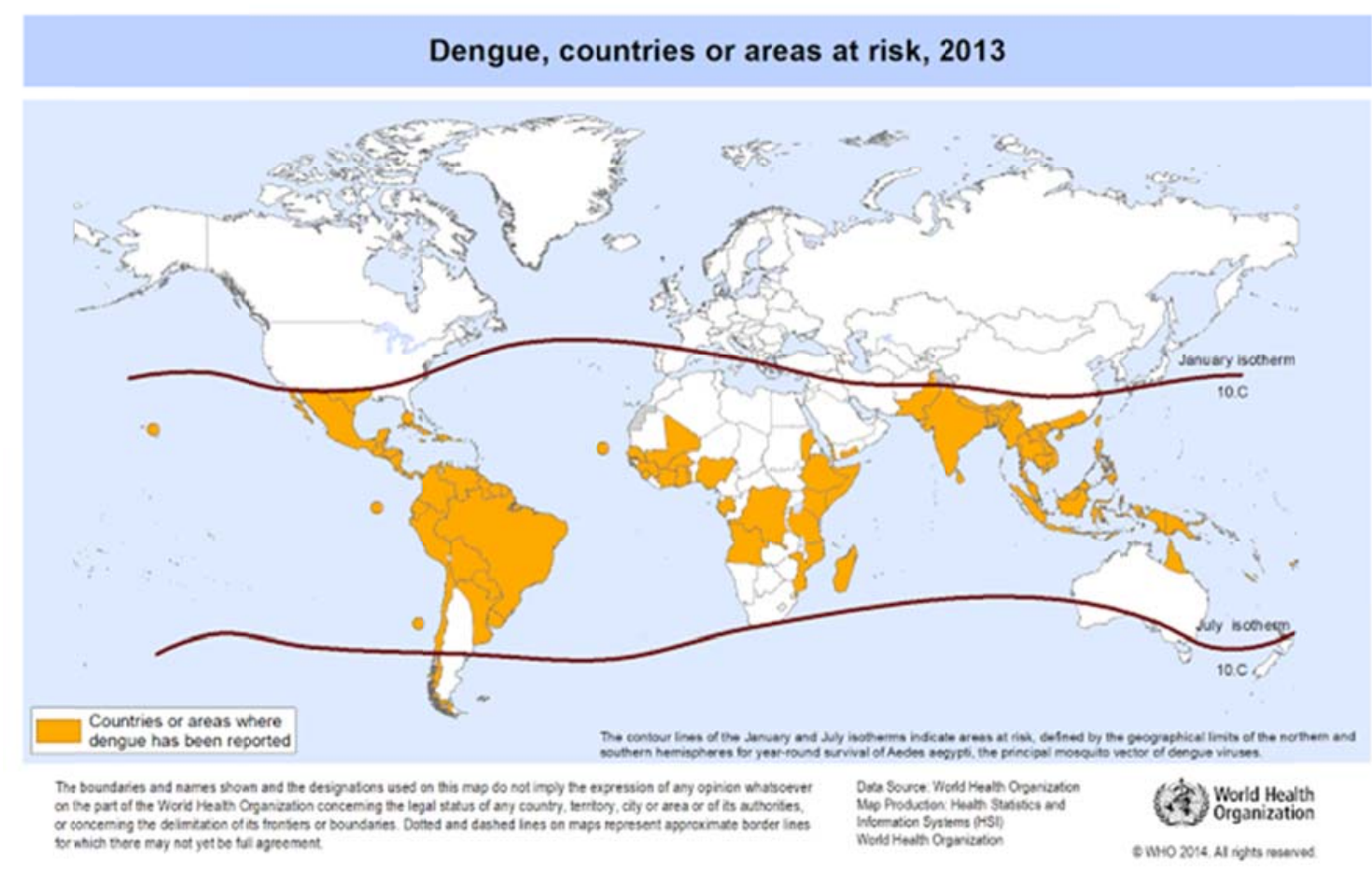

Figura 11: Mapa das áreas onde a dengue foi registrada. Fonte: Organização Mundial da Saúde, 2013. 

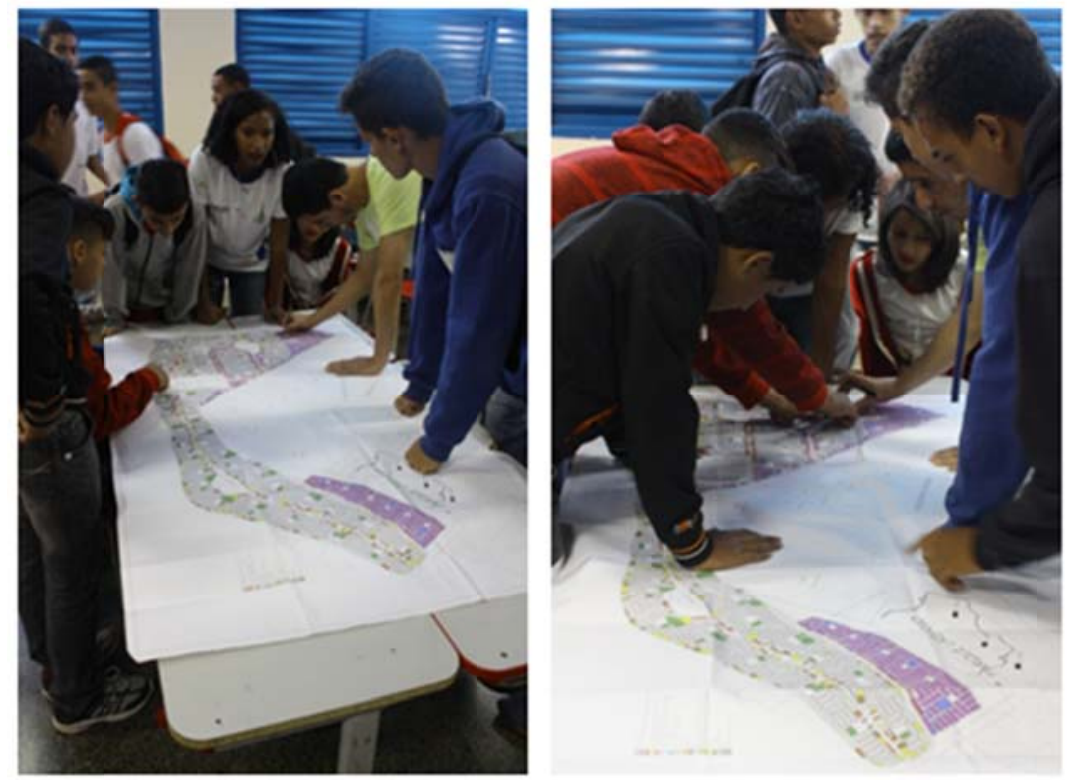

Figura 12: Exploração do mapa da cidade pelos alunos. Fonte: Lívia Miranda de Oliveira

As atividades alcançaram êxito com relação ao objetivo proposto. A avaliação dos conteúdos estudados em sala foi dada por meio de exercícios de fixação.

\subsubsection{Quarto ciclo - Aulas interdisciplinares de Geografia e Ciências}

Para dar continuidade aos trabalhos a comunidade investigativa definiu o seguinte objetivo conforme o plano de aula no anexo 5: rever o ciclo da doença para debater as possíveis formas de interrupção do mesmo; debater com os alunos a ideologia apresentada pelas campanhas de combate ao vetor para a elaboração de materiais complementares às informações divulgadas; fixar os fatores geográficos onde $\mathrm{o}$ mosquito sobrevive; destacar os fatores geográficos do Continente Americano.

Foram necessárias três aulas para a execução do planejamento do quarto ciclo. Utilizaram-se slides sobre os conteúdos envolvidos, exposição dos cartazes das campanhas do Ministério da Saúde 2015 e GDF 2016 de combate à dengue.

\section{Primeira aula - Quarto Ciclo}

A aula iniciou com explicações sobre o ciclo da doença. A pesquisadora enfatizou que o mosquito, exceto nas transmissões verticais, se contamina ao picar uma pessoa contaminada. Afirmado isso observou-se que o ponto significativo da primeira 
aula foi o espanto dos alunos ao perceberem que o mosquito não nasce contaminado, algumas falas registradas:

- “quer dizer então que o homem é que contamina o mosquito?”

- "eu pensava que o mosquito nascia com a doença?”

- “então a culpa é do homem que contamina o mosquito”

- "você tá me dizendo que o doente é que contamina o mosquito?”

As falas significativas corroboram a hipótese levantada no projeto de que "a ideologia de combate exclusivo ao Aedes aegypti difundida pelas campanhas brasileiras oficiais de combate à dengue leva a um conhecimento insuficiente/deturpado sobre o ciclo da doença e das medidas preventivas possíveis".

O conhecimento insuficiente levantado na hipótese está direcionado à compreensão incompleta do ciclo da dengue e o conhecimento deturpado torna-se um produto do primeiro, que ao se constituir incompleto corrompe e encolhe os meios de prevenção ao único comportamento de combater o mosquito.

Em meio à exposição oral um dos slides trazia a tabulação da questão "De que forma podemos reduzir ou eliminar a doença na nossa cidade?" que foi respondida pelos discentes no questionário do primeiro ciclo. O questionário revelou que para os alunos, a única forma de combate à doença é a erradicação do vetor evitando a água parada pelo acúmulo de lixo.

A partir do conhecimento coletado pela questão e apresentadas as respostas aos alunos, a seguinte questão provocadora foi lançada:

- Será que as respostas unânimes em combater o mosquito podem ter sofrido alguma influência de informações externas?

No mesmo momento muitos responderam que sim, que isso vinha do que eles tinham aprendido na televisão. Na sequência, a comunidade expôs os cartazes das campanhas e, munidos de conhecimentos científicos a respeito do ciclo da doença e formas de prevenção, os participantes dialogaram sobre as ideologias que envolvem as mensagens, dentre elas a de que se uma espécie de ser vivo prejudica os seres humanos, esta perde o seu direito de existência.

Os debates conduziram as turmas à conclusão de que pensando assim, muitas outras espécies de seres vivos que ameaçam ou prejudicam os seres humanos também não teriam a chance de existir, incluindo o próprio homem, que prejudica e até mata a própria espécie. A comunidade refletiu com os discentes sobre a interpretação 
antropocêntrica da realidade que coloca o meio ambiente a mercề de perdulários comportamentos humanos constituindo uma situação de crise civilizatória (Leff, 2010; Sorrentino, 2005).

O momento vivido foi a oportunidade de levantar discussões sobre sustentabilidade, as dimensões que ela envolve e o que seria possível fazer para melhorar a realidade da comunidade escolar envolvida.

Seguindo as atividades propostas, os alunos fizeram a leitura individual do texto Dengue (Bazin, 2008) seguida de uma apresentação de formas de prevenção. Além das atividades exaustivamente difundidas nas campanhas oficiais de evitar acúmulo de lixo, limpar calhas frequentemente, virar garrafas, etc. para combater a água parada e não deixar a população do vetor aumentar foi destacado que os doentes podem adotar medidas para evitar, durante o período infectivo ${ }^{20}$, a contaminação do mosquito.

Essas medidas poderiam ser o uso de telas contra insetos em portas e janelas de residências, uso de repelentes naturais ou industrializados, repouso sob mosquiteiros, uso de roupas que cubram a pele o máximo possível, na tentativa de quebrar o ciclo entre os elementos homem contaminado-vetor. Para ilustrar as novas medidas de combate (observar a figura 13).

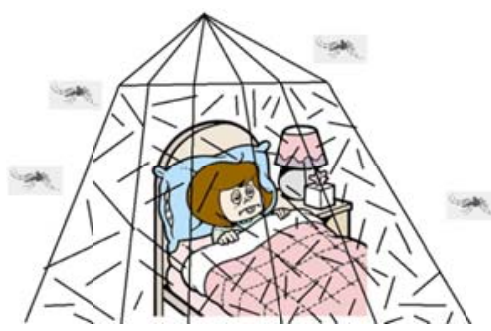

Figura 13: Representação dos cuidados que podem ser tomados pelos doentes durante a fase infectiva. Fonte: Lívia Miranda de Oliveira adaptada de http://escolaamericanos.blogspot.com.br/2011/02/dengueaqui-nao.html.

$\mathrm{Na}$ sequência, para problematizar o alcance das medidas informadas pelas campanhas oficiais e refletir sobre a complexidade dos elementos que envolvem a incorporação de atitudes sustentáveis, a comunidade investigativa projetou as três figuras a seguir:

\footnotetext{
${ }^{20}$ O período em que o doente deve se prevenir de ser picado é até o sexto dia da doença, quando o vírus da dengue permanece circulante no sangue de um humano em viremia, e é ingerido pela fêmea do mosquito durante o repasto. Portanto, trata-se de um esforço redobrado de apenas uma semana.
} 

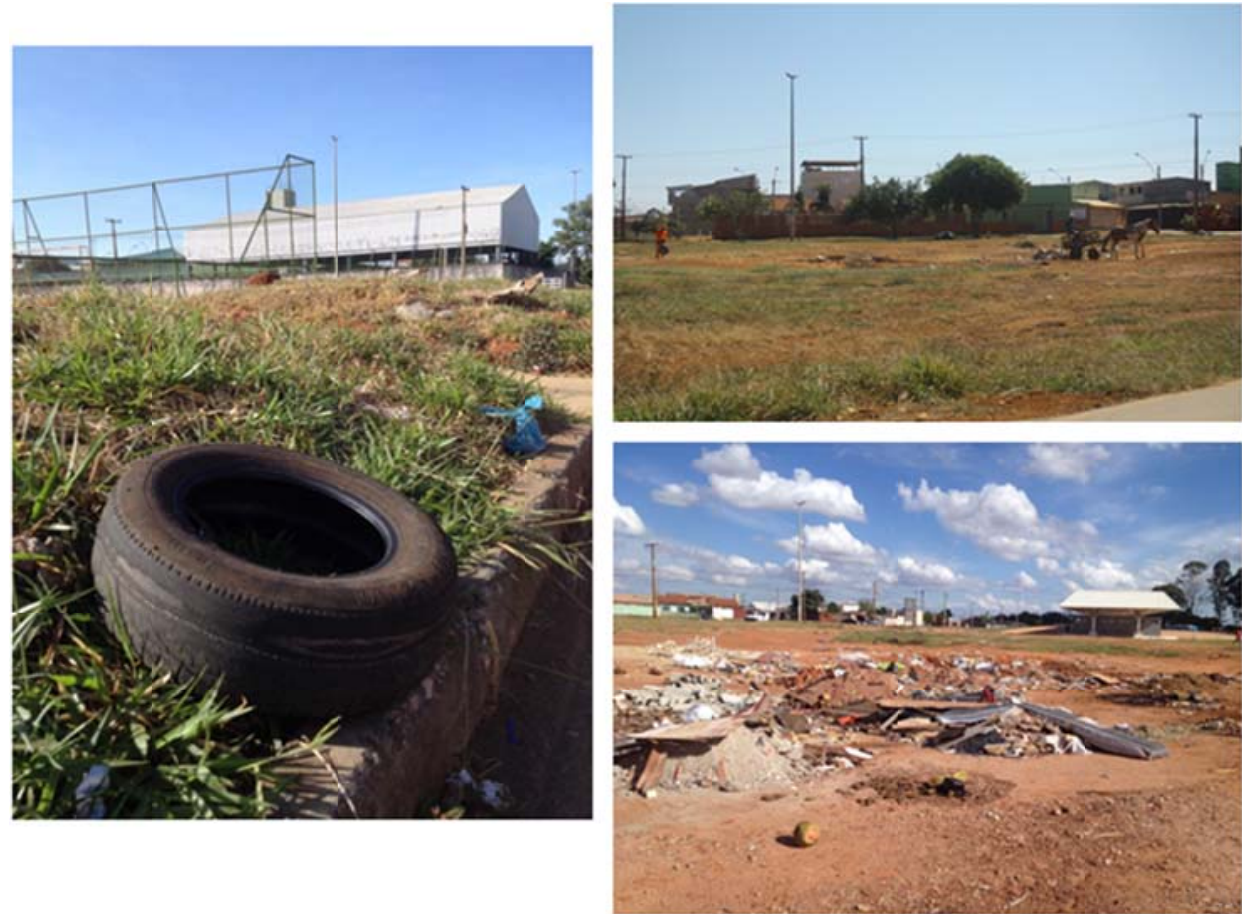

Figura 14: Lixo nos arredores da escola.

Fotos: Lívia Miranda de Oliveira

Observou-se euforia e identificação com seu cotidiano no momento em que fotografias de locais próximos à escola foram mostradas nos slides. Foi informado que as fotografias correspondem a alguns locais que eles apontaram no questionário do primeiro ciclo como possíveis focos para a existência do mosquito.

Mostradas as fotografias foi feita uma reflexão sobre o comporttamento humano e o meio ambiente e incorporando-se às reflexões a pergunta provocadora foi lançada: Será que o combate aos focos do mosquito está sendo eficiente? - onde muitos se posicionaram com as seguintes falas:

$$
\begin{gathered}
\text { “tá vendo, não adianta” (aluno 1) } \\
\text { “como o Recanto das Emas é feio” (aluno 2) } \\
\text { “eu falei que nesse lugar tinha lixo” (aluno 3) } \\
\text { “o povo não faz a sua parte” (aluno 4) } \\
\text { “estamos correndo risco de pegar a doença” (aluno 5) } \\
\text { “eu já até denunciei minha vizinha que joga lixo aí” (aluno 6) }
\end{gathered}
$$

As percepções envolvendo sustentabilidade seguiram partindo de problematizações levantadas sobre como descartar os resíduos sólidos sem prejudicar o 
meio ambiente, e dentre as discussões, o aluno 6 relatou que a denúncia fez mais efeito do que as campanhas de conscientização, ao observar que sua vizinha mudou o comportamento.

Como a pesquisa-ação educativa desde o seu inicio demonstrou abertura para manifestação entre seus participantes, foram divulgados os e-mails e números de WhatsApp da comunidade investigativa para facilitar a comunicação com os alunos. Por essas vias, a comunidade recebeu uma filmagem realizada por um grupo de alunos participantes do projeto que, em tom de denúncia, levou ao conhecimento da comunidade uma situação de conflito socioambiental (Little, 2001; Scotto, 1997) ${ }^{21}$ vivenciado dentro da escola com potencial para se tornar criadouro de Aedes aegypti, dentre outros.

O local da filmagem, por ser em uma área de não circulação, era desconhecido até aquele momento pelo professor regente e a pesquisadora. A comunidade fotografou o local (figura 18) e projetou a imagem no final da primeira aula do ciclo 4, estimulando discussões sobre a situação.

A denúncia dos alunos sobre a situação de acúmulo de cadeiras e carteiras atrás de um bloco de salas dentro do CEF 602 do Recanto das Emas foi incorporado pelo projeto como um elemento importante a ser trabalhado. A concepção da comunidade investigativa foi de encontrar e realizar ações positivas para o conflito, mas até que o grupo chegasse a realizar ações, o primeiro passo foi levar a situação ao o conhecimento das turmas de oitavo ano e discutir a situação.

\footnotetext{
${ }^{21}$ Disputas entre grupos sociais como consequência dos diferentes tipos de relação que eles mantêm com seu meio natural (Little, 2001), e expressam relações de tensão entre interesses coletivos e privados sob a dinâmica de uso ou apropriação do território, refletindo a disputa pelo uso do meio ambiente comum (Scotto, 1997).
} 


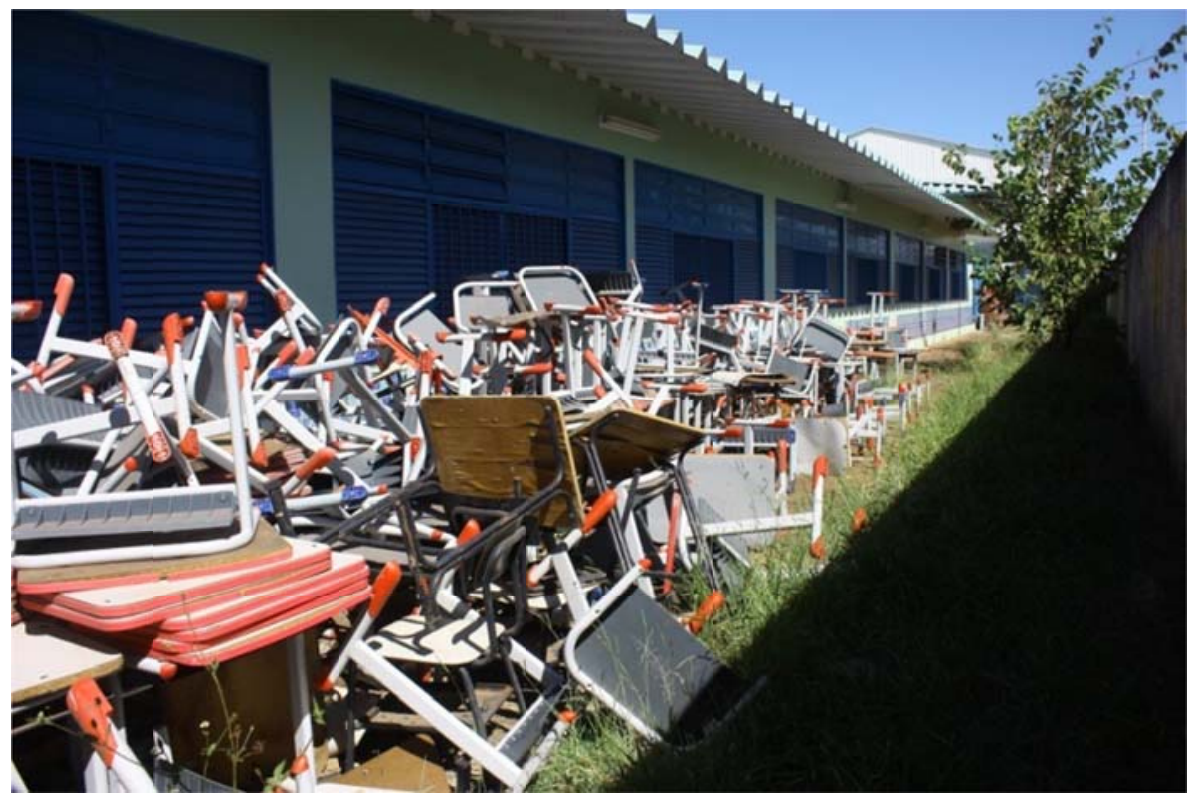

Figura 15: Conflito socioambiental denunciado pelos alunos.

Fonte: Lívia Miranda de Oliveira.

Finalizada a aula, a comunidade observou que os alunos compreenderam/conheceram: i) o ciclo da doença; ii) que o combate à dengue seria mais eficiente se, agregando aos cuidados com a água parada já difundidos pelas campanhas oficiais, os doentes diagnosticados tentassem evitar a contaminação do mosquito, adotando medidas como o uso de repelentes e barreiras físicas (como mosquiteiro e telas em janelas); iii) a ideologia antropocêntrica que envolve as campanhas oficiais de combate à dengue no Brasil; iv) um conflito socioambiental dentro da escola.

Mal se iniciaram as atividades planejadas para o quarto ciclo e este já sinalizou que teria ramificações significativas. Uma delas perpassa os momentos de estudos e coordenação da comunidade investigativa. Durante o planejamento da primeira aula, a escolha do texto Dengue de Maurice Bazin (2008) foi imprescindível para justificar as novas formas de prevenção propostas pelo projeto. O posicionamento favorável ao socialismo que o autor faz no final do texto levou a comunidade a fazer a seguinte observação no final da leitura pelos alunos: "não é objetivo da aula realizada tomar posicionamento favorável ou contrário, ou ainda influenciar adesões aos pensamentos liberalista ou socialista. Cabe a cada cidadão fazê-lo ou não através do decurso de seus estudos, vivências e observações pessoais".

O não aprofundamento sobre as correntes interpretativas liberalista e socialista da realidade foi decidido pela comunidade após algumas reflexões, dentre elas as de 
que, embora a possibilidade da transposição didática, a maturidade e os pré-requisitos de conteúdos aliados ao tempo disponível não eram adequados para o momento. Foi feita a tentativa de discutir a questão envolvendo as aulas de história com o convite da comunidade investigativa para a professora regente, que por sua vez sabia do projeto em andamento, mas alegando que iria interferir no planejamento bimestral de "sua" disciplina, a professora não quis participar.

A comunidade considerando que esta é uma discussão que pressupõe leituras direcionadas ao tema e que necessitariam de mais tempo, a temática não foi aprofundada com os discentes.

Mesmo a comunidade consciente de que o posicionamento favorável ou contrário às correntes referidas é uma questão livre para cada cidadão, existiu a necessidade de refletir a questão e a sua abordagem em sala de aula em especial pelas pressões vivenciadas pelo meio educacional como o projeto de lei (PL) 867/2015 identificado como "Escola sem partido".

Esse tema foi levantado para a reflexão da comunidade pela pesquisadora, e durante os diálogos da CI que ocorrera na sala de professores, outros docentes ouvindo a conversa manifestaram interesse no assunto alegando "não estar sabendo do PL". A comunidade investigativa imediatamente incluiu-os na discussão mostrando a página do projeto na internet, o que causou inquietação generalizada.

A característica do corpo docente da escola envolvida muitas vezes observada pelo professor regente de que, "trata-se de um grupo antigo na escola e que só reclama dos alunos e não enxerga o que está acontecendo além das paredes das salas de aula" confirmou a percepção. Este elemento foi aproveitado para a reflexão da questão de pesquisa, que buscou saber se é possível superar a mera constatação de problemas/entraves no ambiente educacional das escolas públicas no DF para incorporar a pesquisa-ação em EA por meio da formação continuada? A experiência vivenciada demonstrou que sim.

Nos momentos de reflexão do ciclo 4, a comunidade debateu sobre o referido PL percebendo-o como uma tentativa impositiva de controle sobre os conteúdos ensinados pelos professores, sob a espúria visão da neutralidade política e ideológica no território escolar.

As reflexões comungaram da acepção Freireana (1996) de que quando vivemos a autenticidade exigida pela prática de ensinar-aprender participamos de uma 
experiência, dentre outras, política. O componente político inerente aos seres racionais, não poderia ser separado deste, na medida em que se considera que educar é praticar a liberdade, uma prática educativa só poderia alcançar efetividade mediante a participação livre e crítica dos envolvidos no processo (Freire, 1983).

A segunda ramificação importante verificada no quarto ciclo envolveu o conflito socioambiental denunciado pelos alunos. Verificada e fotografada a situação a comunidade investigativa concordou que era necessário saber mais sobre a situação, assim como a questão da não disponibilidade do laboratório de informática foi verificada em instâncias competentes, a mesma atitude foi demonstrada conscientemente pelo professor regente, explicitando que uma postura mais investigativa estava sendo incorporada, e que a consciência surge de e é moldada pela prática, e por sua vez é julgada em e pela prática (Carr e Kemmis, 1986, p.161).

No dia 17/06/2016 a comunidade se reuniu com a diretora da escola na coordenação pedagógica no período vespertino. Os objetivos planejados para a reunião foram: apresentar para a gestora os apontamentos realizados pelos alunos relacionados a uma situação que tem potencial para se tornar foco do mosquito, pelo acúmulo de cadeiras e carteiras a céu aberto em uma área dentro da escola; conferir se existe algum planejamento por parte da direção relacionado à situação; discutir possibilidades para a resolução da situação.

A gestora informou que já é uma preocupação da equipe em dar destino ao material e que foi feita solicitação de recolhimento à Coordenação Regional de Ensino (CRE) Recanto das Emas. Esta dispõe de um único caminhão para atender a todas as escolas da cidade. Segundo a diretora, a retirada do material está agendada possivelmente para o final do ano de 2016. Ao longo da reunião, a vice-diretora, que tem seu trabalho mais voltado para a organização do patrimônio da escola, entrou no ambiente e a diretora falou da situação que, por sua vez, informou à CI que o material, por ser de modelo novo, não estava sendo recolhido pela SEDF.

Diante disso a diretora sugeriu à comunidade a realização de um mutirão com a participação dos alunos envolvidos no projeto para a remoção e organização do material para um local parcialmente coberto.

Para dar sequência, no dia 20/06 durante o período vespertino a CI se reuniu com o coordenador da UNIAG (Unidade de Administração Geral-CRE Remas) e buscou informações atualizadas sobre a situação, o coordenador informou: 
$\checkmark$ O recolhimento do material é possível sim, porém na gestão do governo vigente a burocracia está maior o que torna o processo moroso.

$\checkmark$ No ano de 2016 a escola recebeu mais de 100 cadeiras e carteiras, porém a reposição desse material não é garantida para os anos posteriores, sendo talvez mais interessante para a escola a recuperação do material.

$\checkmark$ O CEF 602 recebeu mobiliário novo completo há cerca de quatro anos, o que demonstra um alto índice de depredação do patrimônio por parte dos alunos, sendo talvez mais interessante recuperar o que for possível e trabalhar o respeito e conscientização sobre os patrimônio público com os alunos.

$\checkmark$ O coordenador citou alguns exemplos de sucesso em escolas do Recanto das Emas (CED 104 e CEF 113) que trabalharam projetos para a proteção do patrimônio público que poderiam servir como exemplo para desenvolver ações nesse âmbito no CEF 602.

$\checkmark$ Caso a comunidade escolar optasse por enviar o material para depósito, o coordenador sugeriu que fosse feita uma separação dos modelos de cadeiras e carteiras para facilitar o recolhimento e, se possível, os servidores da empresa responsável pelos serviços gerais da escola, retirassem os tampos de madeira das carteiras.

Após a reunião com o coordenador da UNIAG, a comunidade investigativa concluiu a necessidade de consultar os alunos sobre o que fazer para solucionar essa situação, em um movimento de escuta atenta a todos os segmentos envolvidos no processo, para democratizar as futuras ações.

\section{Segunda e Terceira Aula}

A segunda aula do quarto ciclo se voltou para as questões ecológicas que envolvem o grupo taxonômico dos mosquitos, o qual o Aedes aegypti pertence. Foram explanados conhecimentos sobre a participação nas cadeias tróficas, reciclagem da matéria e o tempo de existência dos mosquitos no planeta (cerca de cem milhões da anos). Conforme a literatura, o mosquito é originário do Egito, daí o nome da espécie aegypti, e na oportunidade o mapa do continente africano foi estudado e retomado o mapa da OMS (figura 14). 
Com as explorações dos mapas, os fatores geográficos que influenciam a vida do vetor foram explanados: latitude, altitude, maritimidade, continentalidade, relevo, massas de ar, vegetação, população / urbanização. Apresentados estes fatores, a caracterização dos mesmos elementos no continente americano foram destacados, conforme o currículo em movimento das escolas públicas do DF.

Para a fixação dos conhecimentos apresentados, os alunos fizeram uma leitura individual do texto $\mathrm{E}$ se todos os Aedes aegypti fossem exterminados? de Eduarda Esteves que aborda a inconsistência da ideia de erradicação total de uma espécie do planeta. Segundo o mesmo texto não há consenso na comunidade científica sobre a extinção de uma ou mais espécie e os impactos ambientais que poderiam ocorrer.

Após leitura do texto a pergunta "o ser humano pode determinar o direito de existência de uma ou mais espécie viva no planeta?" foi lançada aos alunos para que tentassem refletir sobre a questão. No mesmo momento alguns responderam que não, outros que só quem pode determinar o direito de existência é Deus, outros se manifestaram dizendo que se for assim não vai sobrar mais ninguém na Terra.

O quarto ciclo foi concluído na terceira aula com a aplicação de exercício de fixação e a confecção do livro de uma folha só (adaptação de material fornecido pelas Oficinas Pedagógicas do DF) com um resumo dos temas estudados (anexo 6).

As problematizações realizadas ao longo do projeto levaram os discentes e a comunidade investigativa à percepção de que era preciso divulgar tudo o que lhes foi revelado às outras pessoas, as informações não cabiam mais dentro das paredes das salas de aula. Surgia assim o quinto ciclo.

\subsubsection{Quinto ciclo - Preparativos para a Feira de Ciências Local.}

As ações praticadas no quarto ciclo revelaram que era importante mostrar para a comunidade escolar as questões debatidas pelo projeto, uma vez que o assunto envolvia todos os cidadãos. Como a feira de ciências da escola estava próxima, a comunidade investigativa decidiu formar um grupo que apresentaria o projeto e seus andamentos.

Durante o planejamento da ação um desafio necessitou ser transposto: a divisão das turmas participantes da feira. A coordenação pedagógica da escola decidiu que cada professor iria expor os trabalhos das turmas em que são conselheiros. Como o professor 
regente era conselheiro de uma turma de sétimo ano, segmento que não participou do projeto, a sugestão dada pela coordenação da escola seria fazer uma troca com outro professor.

A comunidade apoiada pela coordenadora pedagógica expôs em reunião coletiva a situação onde foi pedido aos professores dos oitavos anos uma troca de turmas. Como resultado, mesmo constatando que a maioria dos professores não havia definido o que iriam trabalhar para a feira de ciências, nenhum profissional aceitou a troca.

Como o professor regente compreendia que a exposição dos andamentos do projeto na feira era de importância ambiental e social, este assumiu a coordenação de dois trabalhos concomitantes, um da turma da qual era conselheiro e outro foi formado pela comunidade investigativa com o apoio da direção e da coordenação da escola.

Para a ação foram escolhidos oito alunos dos oitavos anos, e mesmo contrariando a opinião de alguns professores, formou-se um grupo especial (como autodeterminado pelos alunos) responsável pela exposição do projeto.

\section{ROTEIRO PARA FEIRA DE GIÊNGIAS}

\section{Introdução}

$\checkmark$ Explicações gerais sobre a doença no mundo (mapa da OMS) e os casos no Recanto das Emas (mapa com as marcações).

\section{Ciclo da doença}

$\checkmark$ Enfatizar que o mosquito não nasce contaminado;

$\checkmark$ Ecologia e geografia do mosquito;

$\checkmark$ Mostrar o Kit da Vigilância Ambiental - fases de desenvolvimentto do mosquito.

\section{Reflexões sobre o combate à doença}

\section{1}

$\checkmark$ Mostrar que a prevenção no Brasil se posiciona no combate ao mosquito;

$\checkmark$ Mostrar que só combater água parada não tem resolvido.

$\checkmark$ Levar à reflexão e ilustrar o insucesso das campanhas de combate usando fotos dos alunos e professores;

$\checkmark$ Acrescentar os cuidados que os doentes devem tomar para não contaminar os mosquitos; comparar com o modelo de Cuba.

\section{2}

$\checkmark$ Prevenção pela alimentação - vitaminas do complexo B; suco repelente.

4. Reflexão e crítica às campanhas nacionais

Você acha que o ser humano pode determinar o direito de uma espécie existir? Analisar os cartazes das campanhas.

5. Jogos produzidos pelo projeto.

Sugestão final: produzir um folder com as informações sobre o combate. 
O planejamento da feira foi dialogado com o grupo que se reuniu em vários momentos no contraturno e juntos, CI e discentes, planejaram o roteiro de exposição apresentado na página anterior.

O grupo discente e a comunidade investigativa selecionaram os materiais utilizados nos ciclos anteriores - como o mapa da cidade demarcando os casos de dengue, as tabulações da primeira ação do projeto, livro de uma folha só, folders e cartazes das campanhas oficiais de combate a dengue - organizando-os de forma que facilitasse a exposição.

Uma maquete representando como um doente poderia repousar e se isolar dos mosquitos foi confeccionada pelos alunos, além de cartazes, fotografias e um suco repelente, cujo ingrediente principal foi o inhame.

O quinto item do roteiro correspondeu a um jogo da memória (anexo 7) que foi elaborado pela comunidade investigativa que buscou uma forma lúdica de revisão e fixação dos conteúdos e discussões do projeto. O material utilizado na confecção do jogo foi doado pela Oficina Pedagógica do Gama, que disponibilizou doze caixas de MDF contendo 40 peças de $5 \times 5 \mathrm{~cm}$ do mesmo material. A comunidade investigativa fez a elaboração epistemológica do jogo e o grupo participante da feira de ciências ficou com a montagem e produção das caixas dos jogos.
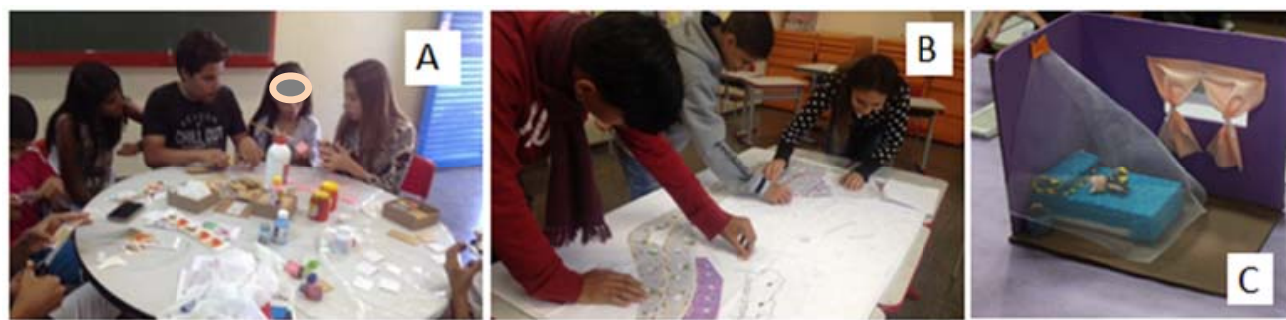

Figura 16: Preparativos dos materiais para a feira de ciências local.

(A)Confecção do jogo da memória; (B) Demarcação dos casos de dengue no mapa do Recanto das Emas; (C) Maquete representando medidas preventivas.

Fonte: Lívia Miranda de Oliveira

A reflexão principal tecida no quinto ciclo envolveu a resistência do corpo docente frente ao pedido de divisão de turmas. Em oposição à mesma, a equipe gestora da escola e a coordenadora pedagógica demonstraram grande esforço para a participação do grupo na feira local, apoiando a equipe com materiaiis de consumo e humano.

A CI percebia que os obstáculos e as facilidades do percurso da pesquisa-ação educativa eram postos algumas vezes pelos mesmos atores, e na medida em que as fases 
da espiral cíclica aconteciam o projeto se consolidava, as ações refletidas e praticadas fortaleciam a investigação. $\mathrm{O}$ empoderamento da comunidade investigativa se dava a partir da prática que explicitava para a comunidade escolar um compromisso concreto com a educação.

\subsubsection{Sexto ciclo: Feira de ciências etapa local.}

A SEDF em suas subsecretarias promove anualmente o Circuito de Ciências das Escolas da Rede Pública de Ensino do DF dividido em três etapas: local - feira de ciências realizadas nas escolas; regional: mostra dos dois principais trabalhos por segmento da educação básica selecionados pelas escolas na etapa local e que são apresentados para as comunidades em cada cidade satélite do DF; distrital: expõe os trabalhos selecionados na etapa regional selecionando os mais qualificados.

O projeto de combate a dengue expôs na etapa local suas atividlades seguindo o roteiro elaborado no ciclo anterior. Uma dificuldade encontrada antes do inicio da exposição deu-se por não haver um espaço destinado ao grupo. A questão foi resolvida quando um professor permitiu que o grupo dividisse espaço com a sua turma participante da feira.

$\mathrm{Na}$ medida em que as apresentações iam ocorrendo (figura 17), os alunos adquiriam confiança e melhoravam suas explicações. As duas pessoas destinadas a avaliarem o projeto demonstraram interesse sobre o assunto e uma delas revelou que também não sabia que o mosquito nascia descontaminado na maioria dos casos. Isso motivou os alunos a perguntarem para os visitantes se eles sabiam da informação, demonstrando a adoção de uma postura investigativa.

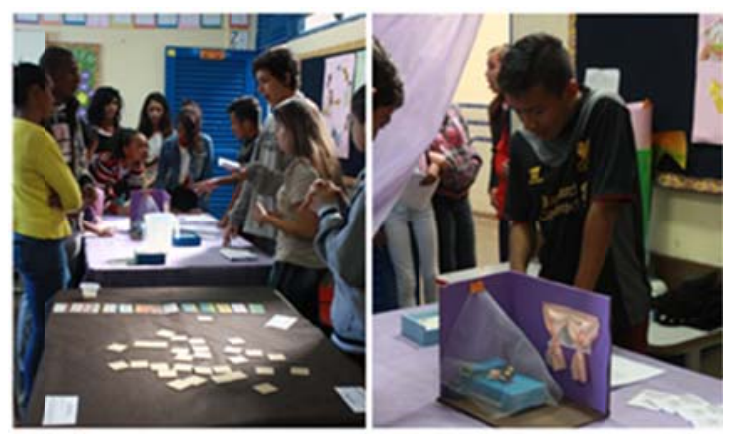

Figura 17: Alunos expondo o projeto na feira de ciências local. Fonte: Lívia Miranda de Oliveira 
Finalizada a exposição, na mesma semana a coordenação da escola divulgou os resultados das avaliações e o grupo alcançou nota máxima no projeto. Devido ao bom andamento das atividades, o grupo foi convidado a participar da feira de ciências na etapa regional, e os envolvidos aceitaram o convite.

A comunidade investigativa refletiu que a participação dos alunos na exposição, ultrapassados os entraves foi positiva. O exercício de elaborar e sistematizar uma explicação, responder e refletir os questionamentos dos visitantes ajudou-os a superar a falta de confiança, melhorar a oratória e vencer o nervosismo durante o ato de serem avaliados por pessoas desconhecidas.

Observou-se que os alunos em seus relatos durante a ação incorporaram uma postura investigativa da realidade munida de conhecimentos científicos estudados ao longo do projeto. Isso demonstra que a pesquisa-ação educacional realizada além de potencializar um perfil de investigador entre os professores, alcança os discentes, que ao serem envolvidos na ação investigativa, despertaram um olhar e ações de investigador.

\subsubsection{Sétimo ciclo - Questionário Avaliativo do Projeto.}

Os movimentos prospectivos e reprospectivos da pesquisa-ação educacional realizados até o momento necessitaram verificar seus reais avanços e consultar a opinião discente sobre a resolução do conflito socioambiental. Para isso, no sexto ciclo foi consenso da CI que seria aplicado um questionário avaliativo do projeto.

A aplicação de questionários para Gil (2007) consiste em uma técnica de investigação composta por um número de questões que não deve ultrapassar 30, apresentadas por escrito às pessoas, visando conhecer opiniões, conhecimentos, crenças, sentimentos, interesses, expectativas, situações vivenciadas. O instrumento adotado teria assim capacidade de buscar o objetivo da ação.

O objetivo planejado e divulgado aos alunos foi: verificar a apropriação dos alunos com relação aos conhecimentos científicos sobre o ciclo da doença e levantar opiniões relacionadas à resolução do conflito do acúmulo de mesas e carteiras na escola, apontado pelos próprios alunos ao longo do projeto.

O questionário avaliativo foi aplicado durante as aulas de geografia nos dias 11 e 12 de julho de 2016 e trouxe as seguintes questões:

1. Quem são os três sujeitos componentes do ciclo da dengue? 


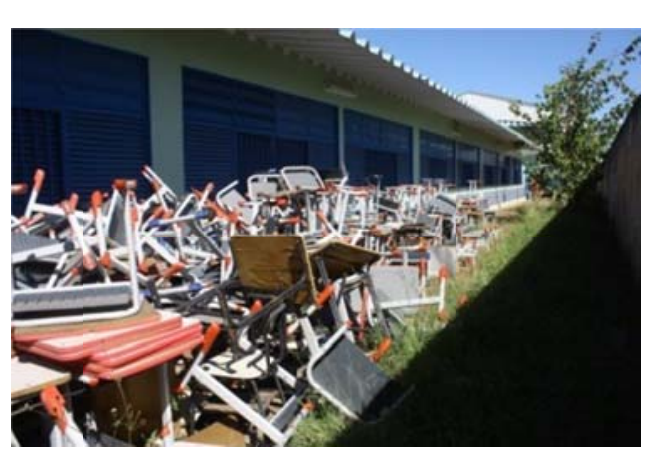

2. Com relação à temática “dengue”, existia alguma informação que você não conhecia e que passou a conhecer a partir das aulas de geografia que envolveu essa temática? Qual foi a nova informação?

3. Após as questões discutidas em sala de aula, quais são as melhores formas de se combater a dengue?

4. Escreva as suas sugestões para resolvermos a situação do acúmulo de cadeiras e carteiras quebradas no CEF 602

conforme a fotografia acima:

5. Em sua opinião, como podemos evitar que a situação mostrada na fotografia anterior aconteça?

A atividade foi realizada em 45 minutos e poucas dúvidas surgiram. Os alunos demonstraram estar confortáveis para responder as questões propostas. A comunidade investigativa refletiu que os conhecimentos registrados no sexto ciclo seriam um ponto relevante para verificar se o projeto promoveu a compreensão do ciclo da doença e formas de prevenção mais completas; quais foram os novos conhecimentos que os alunos desconheciam; consultar as opiniões discentes a respeito de como solucionar o conflito do acúmulo de cadeiras e carteiras a céu aberto dentro da escola.

Nas reflexões, a comunidade decidiu que todas as informações a respeito do conflito socioambiental deveriam ser trianguladas entre as falas da direção da escola, da CRE Recanto das Emas e dos alunos, a fim de buscar os pontos comuns para só assim, de forma democrática, planejar as ações positivas cabíveis à situação.

Dada a importância dos dados que a comunidade tinha disponível e a necessidade de análise minuciosa, surgia o oitavo ciclo da pesquisa-ação educativa que envolveria a tabulação e análise dos dados do questionário avaliativo, a triangulação das informações sobre o conflito socioambiental, a decisão das ações positivas, uma revisão e preparo de materiais para a participação do projeto na feira de ciências regional, que ocorreria no dia 06/09/2016.

\subsubsection{Oitavo ciclo - Estudos e planejamentos: luzes para o encerramento do projeto.}

O planejamento do oitavo ciclo prognosticou quatro ações a serem desenvolvidas pela comunidade investigativa. O objetivo do ciclo foi analisar os andamentos até 
aquele momento para vislumbrar os possíveis ciclos finais do projeto Combate à Dengue.

A primeira ação foi uma reunião com os alunos que iriam participar da etapa regional do circuito de ciências para verificar se o mesmo roteiro de apresentação seria utilizado. Na reunião optou-se pelo replanejamento do roteiro acrescentando outra maquete que ilustraria as formas de interrupção do ciclo. Foi feito um check list dos materiais que já estavam prontos e que poderiam ser reaproveitados e/ou concertados para a etapa regional, verificou-se que de acordo com o edital do certame cada estande deveria expor um banner com especificações do projeto.

A segunda atividade que envolvia o oitavo ciclo consistiu na tabulação e análise dos dados relatados no questionário avaliativo.

Constatou-se nas tabulações que dos 78 alunos que responderam o questionário, em 67 (aproximadamente $86 \%$ ) respostas foi afirmado que participam do ciclo da dengue o homem contaminado, o vetor, o vírus e o homem sadio. No primeiro questionário aplicado no ciclo 1, os alunos só indicavam que participavam do ciclo o homem sadio e o mosquito vetor, o que possivelmente sustentava a ideia de que o mosquito nascia e contaminava o homem. O entendimento correto sobre o ciclo da doença para a maioria dos participantes demonstrou alcance do objetivo proposto no projeto.

Quando questionados sobre algum conhecimento novo adquirido durante a realização do projeto: 54 alunos $(69,2 \%)$ afirmaram não saber que (exceto os casos de transmissão transovariana) o mosquito nascia saudável, e que ele se contamina picando as pessoas doentes.

Como o projeto trouxe o assunto do ciclo da dengue para a escola, nos momentos de conversas informais os quais a comunidade investigativa participou, foi percebido que além dos alunos, muitos servidores da escola incluindo pessoas que atuam na esfera administrativa tanto quanto outros professores confessaram desconhecimento do ciclo da doença, e imaginavam o mosquito como agente causador da dengue, e não como um vetor.

A situação cotidianamente constatada trouxe à reflexão da comunidade de que o desconhecimento do ciclo não é uma questão de escolaridade, pois se ouvia relatos vindos de pessoas com diferentes tipos de formação escolar.

O novo conhecimento adquirido por $69,2 \%$ dos participantes demonstra que conceitos científicos básicos sobre o ciclo da doença necessitam ser passados para a 
sociedade independente do grau de escolaridade cursado. Se a missão de problematizar a temática for dada somente às escolas, há risco de que a situação da epidemia continue a avançar, na medida em que o desconhecimento é da população em geral.

Em cada ambiente o qual a pesquisadora do projeto comentara ou divulgava resultados preliminares do projeto, em ambientes acadêmicos ou não, as reações de desconhecimento da questão eram frequentes.

Sobre as melhores formas de prevenção e combate, as respostas variaram em três grupos como expõe a tabela 3:

Tabela 3: Frequência das formas de prevenção segundo os discentes.

Fonte: elaboração própria a partir das tabulações do questionário avaliativo.

Os dados revelaram que mesmo com pouco tempo de execução o projeto alcançou resultados satisfatórios relacionados à compreensão do ciclo da dengue e medidas de prevenção, podendo demonstrar que ações educativas mais sistematizadas e frequentes sobre o assunto têm potencial para alcançar êxito.

Explicitar de forma persistente o conhecimento científico sobre o ciclo da doença nas campanhas oficiais poderia contribuir para uma concepção coletiva completa e correta sobre a doença, e partindo do conhecimento correto, a população poderia adotar medidas preventivas mais efetivas.

Sobre as melhores formas de se prevenir a dengue, o projeto propõe que após informar cientificamente os cidadãos sobre a doença (ciclo, sintomas, cuidados), as medidas preventivas devem envolver cuidados a serem adotados pelas pessoas doentes evitando a contaminação dos mosquitos, e não exclusivamente combater o vetor como 
já vem sendo preconizado nos materiais de campanha, fator este que não tem alcançado êxito, por diversos fatores, como exemplo a cultura do acúmulo de resíduos sólidos a céu aberto, que não podem ser desconsiderados, mas que apontam para a necessidade de adoção de um novo modelo brasileiro de combate à epidemia da dengue.

As duas últimas perguntas do questionário avaliativo levantaram as sugestões dos alunos para solucionar o conflito (tabela 4) seguindo das opiniões sobre como evitar que situações análogas ocorram novamente.

Tabela 4: Sugestões dos alunos para resolução do conflito socioambiental do CEF 602 do Recanto das Emas.

\begin{tabular}{|c|c|c|}
\hline ORD. & RESPOSTAS & QUANT. \\
\hline 1 & Reaproveitar/ consertar/ reutilizar/ reformar o que for possível. & 25 \\
\hline 2 & Alertar a Secretaria de Educação. & 1 \\
\hline 3 & Conscientizar os alunos sobre a importância da conservação do patrimônio público. & 14 \\
\hline 4 & Jogar fora no lixão da Estrutural. & 4 \\
\hline 5 & $\begin{array}{l}\text { Remanejar o material para um local adequado e reciclar ou reaproveitar o que for } \\
\text { possível. }\end{array}$ & 4 \\
\hline 6 & Jogar fora e trazer novas cadeiras e carteiras. & 2 \\
\hline 7 & Remanejar para outro lugar. & 4 \\
\hline 8 & Remanejar, limpar o lugar e poderia fazer no local uma horta ou jardim. & 9 \\
\hline 9 & $\begin{array}{l}\text { Nós podíamos nos reunir para consertar as cadeiras e carteiras para serem usadas } \\
\text { novamente. }\end{array}$ & 3 \\
\hline 10 & Reaproveitar ou reciclar e conscientizar os alunos a respeitarem o patrimônio público. & 1 \\
\hline 11 & Botar fogo ou arrumar, a escola tem que tomar providências. & 3 \\
\hline 12 & Remanejar e prevenir vandalismos. & 1 \\
\hline 13 & Os alunos são os culpados e não deveriam quebrar mais as cadeiras e carteiras. & 6 \\
\hline 14 & Em branco. & 1 \\
\hline \multicolumn{2}{|r|}{ Total } & 78 \\
\hline
\end{tabular}

Fonte: elaboração própria a partir das tabulações do questionário avaliativo. 
A resposta mais frequente dada por 25 alunos envolveu concepções sustentáveis para a resolução do conflito, pontuando que seria mais eficiente o reaproveitamento do material. A comunidade investigativa concordando com o posicionamento buscou verificar a possibilidade de realizar a ação proposta pelos alunos.

Em segundo lugar a resposta mais frequente corresponde à adoção de medidas que conscientizem a comunidade escolar, e mais especificamente os alunos, para o respeito ao patrimônio público. Essa sugestão foi verificada nas falas dadas tanto pela equipe gestora do CEF 602 como pela CRE, na pessoa do coordenador da unidade de administração geral.

A visão de remanejamento do material acumulado foi frequente em diversas respostas, constatando-se a necessidade de fazê-lo, dada a realidade da falta de espaço na escola. Mas chamou a atenção da comunidade investigativa que nove alunos de turmas diferentes consideram oportuno remanejar e construir uma horta no local.

A sugestão demonstra a presença de sustentabilidade às concepções discentes que por sua vez poderiam ser consultadas com frequência pelo corpo docente. A adoção teórico-metodológica da pesquisa-ação educacional, na medida em que envolve os participantes de forma democrática promovendo ações dialógicas, permitiu a revelação, porém, mais importante do que o revelar por si só seria realizar o ato da revelação.

Em seis respostas dadas, os culpados pelo conflito foram os próprios alunos, identificado por uma pessoa como ato de vandalismo. Apesar de que o assunto gera "brincadeiras" entre os discentes, foi observado durante a ação que, embora a escola atenda alunos do ensino fundamental I no período vespertino, a maioria assume que só existe um culpado: os alunos maiores do turno matutino.

Duas concepções a cerca do destino de resíduos sólidos foram reveladas pelo questionário onde para quatro alunos de turmas diferentes, a solução seria jogar no Lixão da Estrutural $^{22}$ e para outros três alunos a solução seria colocar fogo. Sobre como evitar a ocorrência de situações como a denunciada pelos alunos, as respostas foram compiladas e apresentadas na tabela 5 .

\footnotetext{
${ }^{22}$ Maior depósito de resíduos sólidos a céu aberto da América Latina, popularmente chamado de Lixão da Estrutural.
} 
Tabela 5: Sugestões dos alunos para evitar a reincidência de conflitos análogos.

\begin{tabular}{|l|l|c|}
\hline $\mathbf{N}^{\mathbf{0}}$ & \multicolumn{1}{|c|}{ Respostas } & Quant. \\
\hline $\mathbf{1}$ & Cuidar do material público. & 8 \\
\hline $\mathbf{2}$ & Os alunos pararem de quebrar as mesas e cadeiras. & 22 \\
\hline $\mathbf{3}$ & Evitar criar ambientes que possam ser focos do mosquito. & 4 \\
\hline $\mathbf{4}$ & Não depredando o patrimônio público e cuidando do meio ambiente. & 4 \\
\hline $\mathbf{5}$ & Mandando o governo/regional de ensino retirar e limpar o local. & 3 \\
\hline $\mathbf{6}$ & Reciclar/ reutilizar/ remanejar. & 7 \\
\hline $\mathbf{7}$ & Tendo uma pessoa para fiscalizar as escolas todo mês. & 1 \\
\hline $\mathbf{8}$ & Não deixar lixo jogado. & 6 \\
\hline $\mathbf{9}$ & Evitar acumular e jogar em um local apropriado que não seja na escola. & 8 \\
\hline $\mathbf{1 0}$ & $\begin{array}{l}\text { Punir os alunos que depredam (colocar câmeras na escola para } \\
\text { identificar atos de vandalismo). }\end{array}$ & 5 \\
\hline $\mathbf{1 1}$ & Conscientizar os alunos a não destruírem o patrimônio público. & 9 \\
\hline $\mathbf{1 2}$ & Queimar tudo. & 1 \\
\hline
\end{tabular}

Fonte: elaboração própria a partir das tabulações do questionário avaliativo.

Para 22 participantes, evitam-se situações análogas ao conflito identificado se os alunos pararem de quebrar o mobiliário. As falas número 1, 4 e 11 corroboram a ideia de respeito e cuidado ao patrimônio público e ao meio ambiente, perpassando atividades de conscientização dos alunos. Adotar medidas sustentáveis foram indicadas diretamente nos números 6 e 8. Um aluno sugeriu queimar tudo para evitar a situação despertando um olhar da comunidade investigativa para a temática uso do fogo e resíduos sólidos.

A comunidade investigativa retomou aos registros das reuniões realizadas com a equipe gestora da escola e da unidade de administração geral da CRE Recanto das Emas e triangulou os pontos comuns aos relatos dos alunos com relação ao conflito socioambiental. Perceberam convergências entre as concepções dos envolvidos, o que 
permitiu a tomada de decisão da comunidade pela realização de um mutirão para a organização do material em local protegido das chuvas para facilitar o recolhimento pelo caminhão da CRE Recanto e envio ao depósito central da SEDF.

Por mais que os alunos tenham sugerido o conserto para a reutilização do material, postura esta mais sustentável, a direção da escola explicou que não seria possível. Consta no patrimônio do CEF 602 o recebimento de uma remessa de cadeiras e carteiras no ano de 2016 para substituir o material depredado, não havendo, portanto espaço dentro das salas de aula que comportasse mais mobiliário.

Mas não esgotada a tentativa de reaproveitamento do material, a comunidade foi informada que no depósito central da SEDF é feito o conserto do que for possível e o mobiliário retorna para as escolas do DF que necessitam. A madeira que não pode ser reaproveitada é doada para quem solicita e o ferro vendido, para ser reaproveitado, o que contempla um destino mais sustentável.

O quadro 4 resume-se em três termos: mutirão, conscientização sobre patrimônio público e remanejamento. Consultadas as instâncias envolvidas diretamente com o conflito, a comunidade investigativa concluiu que o último ciclo do projeto seria a realização de um mutirão para a organização, separação e remanejamento do material para um local coberto.

\begin{tabular}{|c|c|c|}
\hline Alunos & Direção & CRE/UNIAG \\
\hline $\begin{array}{l}\text { Reaproveitar o que for possível, } \\
\text { consertar, reutilizar. }\end{array}$ & $\begin{array}{l}\text { Realizar um mutirão para remanejar o } \\
\text { material para debaixo do telhado. }\end{array}$ & $\begin{array}{l}\text { É mais interessante a } \\
\text { recuperação do material uma } \\
\text { vez que a reposição para os } \\
\text { anos posteriores não está } \\
\text { garantida. }\end{array}$ \\
\hline $\begin{array}{l}\text { Conscientizar os alunos sobre a } \\
\text { importância da conservação do } \\
\text { patrimônio público. }\end{array}$ & $\begin{array}{l}\text { Mudança no comportamento dos } \\
\text { alunos / conscientização dos alunos. }\end{array}$ & $\begin{array}{l}\text { O índice de depredação no } \\
\text { CEF } 602 \text { está alto, o que } \\
\text { demonstra a necessidade de } \\
\text { trabalhar a conscientização do } \\
\text { patrimônio público. }\end{array}$ \\
\hline $\begin{array}{l}\text { Remanejar para local apropriado. } \\
\text { Podemos fazer um mutirão. }\end{array}$ & $\begin{array}{l}\text { Recolhimento pelo caminhão e } \\
\text { remanejar para o depósito da SEDF. }\end{array}$ & $\begin{array}{l}\text { O recolhimento é moroso, } \\
\text { mas possível. Seria } \\
\text { importante separar o material } \\
\text { por tipo para facilitar o } \\
\text { recolhimento. }\end{array}$ \\
\hline
\end{tabular}

Quadro 4: convergências entre alunos direção e CRE sobre resolução do conflito socioambiental.

Fonte: elaboração da comunidade investigativa. 
Finalizadas as ações previstas para o oitavo ciclo, a comunidade investigativa refletiu que o próximo ciclo - circuito de ciências etapa regional - estava praticamente concluído, faltando somente a confecção do banner, e que em relação aos dados analisados no questionário avaliativo, as concepções 1 e 2 reveladas pelos alunos deveriam ser comentadas em sala de aula: o descarte de lixo para o lixão da Estrutural e a cultura de colocar fogo no lixo.

Ambas as concepções eram merecedoras de aprofundamento e discussões sistemáticas, talvez um novo projeto devesse investigar e aprofundar os assuntos, o que não foi possível dada a proximidade da finalização das atividades de pesquisa. $O$ professor regente não descartou a possibilidade de investigar e discutir os assuntos com os alunos em momentos posteriores, sinalizando uma mudança de discurso que poderia engatilhar a possível mudança da práxis docente, anteriormente mais voltada para os conteúdos curriculares seguindo-se o livro didático. Após a vivência da pesquisa-ação em educação ambiental, a postura sinaliza uma atuação mais compatível a de um professor-investigador.

O oitavo ciclo ocorreu no final do segundo bimestre de 2016, período em que se realiza o conselho de classe do CEF 602 do Recanto das Emas. Este pratica o conselho de classe participativo, ou seja, reúnem-se o corpo docente, a equipe de coordenação e direção da escola e os alunos representantes de turma. O momento é destinado para a avaliação das atividades escolares do bimestre, onde ocorre a leitura de uma ficha de pré-conselho que registra as avaliações e sugestões dos alunos para as atividades escolares. Em uma das fichas lidas no conselho de classe surgiu o seguinte registro (anexo 8):

Pergunta 8: O que vocês como turma, acreditam que pode melhorar na sua escola?”

Resposta: "Tirar as cadeiras do muro que pode surgir dengue."

O aparecimento do conflito debatido no projeto na ficha do conselho de classe demonstrou uma postura cidadã ao buscar direitos e um despertar para a situação que, anterior à pesquisa-ação desenvolvida, não tinha acontecido. Os alunos e corpo docente percebiam a situação, mas não refletia, e a não reflexão pode gerar passividade e conivência com a situação.

As reflexões e discussões realizadas nos ciclos da pesquisa-ação deram visibilidade a um conflito que parecia invisível para a maioria dos alunos da escola. $\mathrm{Na}$ mesma questão da ficha de conselho de classe os discentes propuseram o "dia da 
limpeza", sugerindo "pegar os alunos que sujam a escola para eles limparem no sábado". Esta última abarca um tom de punição aos produtores da sujjeira, análogo ao princípio do poluidor pagador da legislação ambiental, o que necessitaria de muita cautela, conscientização e discussão prévia, sob o risco de não alcançar o ato principal, a conscientização.

Nas reflexões finais do oitavo ciclo, o professor regente e a pesquisadora perceberam que o questionário avaliativo comprovou no público investigado a hipótese levantada no projeto Combate à Dengue. O conhecimento insuficiente e deturpado sobre o ciclo prejudica as ações preventivas.

Como pesam sobre os materiais das campanhas oficiais o núcleo da crítica, as reflexões determinaram que seria fundamental encaminhar os resultados do projeto para as autoridades competentes. Após uma pesquisa, foram selecionadas a Coordenação Geral do Programa Nacional de Controle da Dengue (CGPNCD) do Ministério da Saúde, o Secretário do Meio Ambiente do DF (protocolos nos anexos 8 e 9 respectivamente) e a Vigilância Ambiental do DF/SES (encaminhamento via e-mail).

$\mathrm{Na}$ oportunidade, a comunidade verificou que atos propositivos seriam importantes, como a produção de um folder (figura 18) com as concepções do projeto uma vez que o material de campanha foi considerado incompleto.

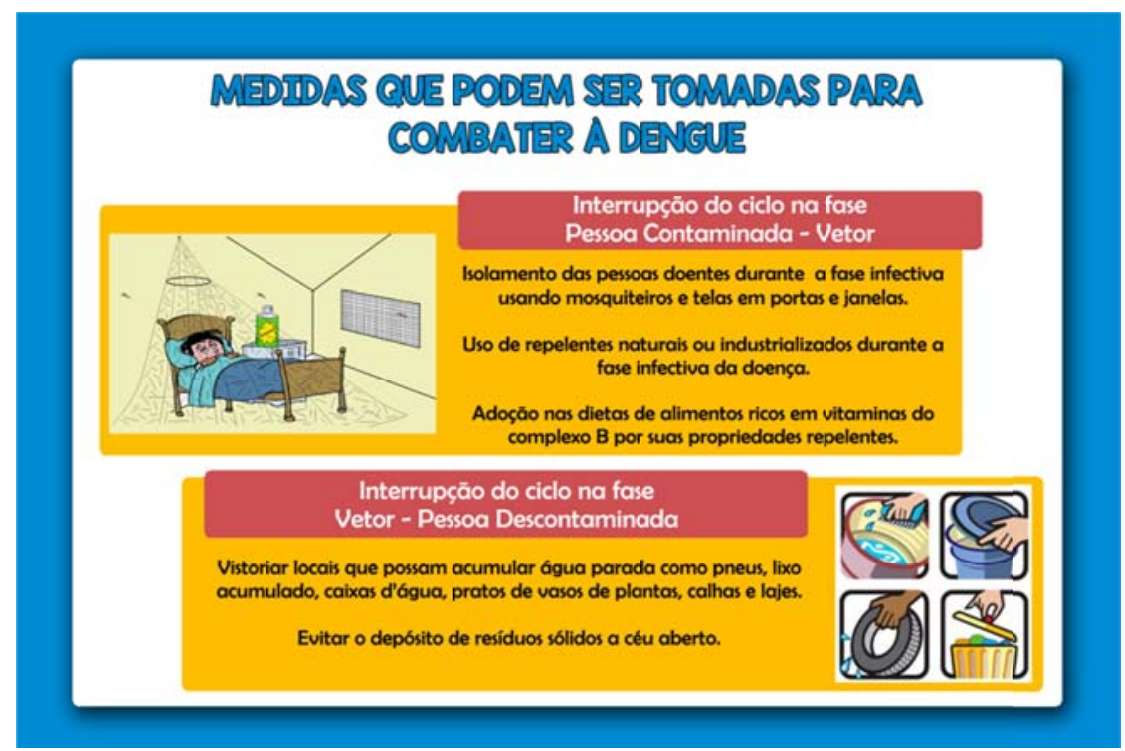

Figura 18: Folder ilustrativo das premissas do projeto.

Fonte: Elaboração da comunidade investigativa. 


\subsubsection{Nono ciclo - Circuito Regional de Ciências}

A atividade principal do nono ciclo foi a exposição do projeto na etapa regional do Circuito de Ciências das Escolas Públicas do DF no dia 06/09/2016. Nesta etapa, os trabalhos selecionados nas feiras de ciências que ocorreram em todas as escolas da cidade do Recanto das Emas foram expostos, no espaço da Vila Olímpica da cidade, nos turnos matutino, vespertino e noturno.

O circuito de ciências segue um tema que é adotado todo ano de acordo com a Semana Nacional de Ciência e Tecnologia do MCTI. Em 2016 o tema adotado pelo circuito de ciências foi "Ciência alimentando o Brasil", onde deveriam ser consideradas as relações do tema do circuito nos trabalhos apresentados. Por esse motivo, o projeto incorporou a questão dos repelentes naturais que poderiam ser confeccionados com alimentos, além de associar às formas de prevenção preconizadas no projeto a adoção de alimentos ricos em vitaminas do complexo B na dieta.

Esse desdobramento conduziu o grupo a determinar um título para o projeto, e após algumas conversas e reflexões, escolheu-se: Dengue, alimentação e prevenção podemos fazer melhor!

O material exposto foi acrescido de um banner, solicitado no edital do circuito, no qual deveriam estar presentes o título do trabalho, autores, introdução, objetivos, metodologia, resultados, considerações finais e referências. A comunidade custeou o banner e se atentou em contemplar todos os elementos para sua elaboração.

No dia da exposição, a CI analisou os pôsteres de variadas escolas verificando lacunas entre os conhecimentos apresentados por algumas escolas e os itens do edital, dentre eles o objetivo geral, metodologia e resultados dos trabalhos, além de problematização rarefeita. Para a comunidade investigativa, o exercício de analisar trabalhos de outras escolas buscando compreender as etapas do método científico presentes contribuiu para o desenvolvimento da visão investigativa, importante a um professor pesquisador (Carr e kemmis, 1986, p. 167).

$\mathrm{O}$ grupo que representou o projeto Combate à Dengue seguiu um roteiro replanejado sobre o primeiro que incluía a apresentação do pôster, de uma maquete de ilha que ilustrava o texto Dengue (Bazin, 2008), um portifólio com todo o material produzido ao longo do projeto (questionários, tabulações, ofícios, atas de reuniões, exercícios, livro de uma folha só, planejamentos, projeto escrito, avaliação bimestral, fotografias, ficha 
do pré-conselho, etc.), uma nova maquete do ciclo da doença pois a primeira havia sido danificada, e folder propositivo (figura 18).

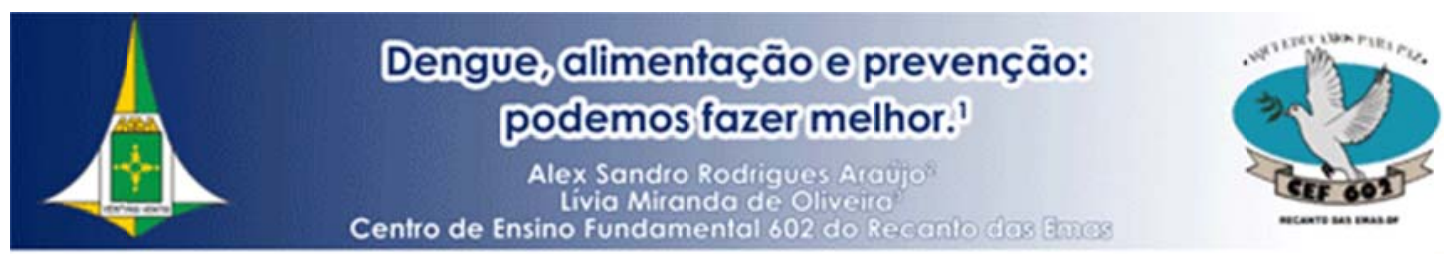

introoucto

O Erasil tem assistido o sumento paulatino do numero de casos de dencue nos Uitimos anos sendo o brasileiro expectador e vitims da epidemia. Os útimos boletins epidemiolevicos publicados pelo Ministerio da saude mostram eve os indices da doensas aumentaram cm relases sos anos anteriores. No Recanto das 1 mas on de Savde/Nielisncia Ambiental.

A siturasto crescente da epidemia pode indicar que as campanhas de combate niso estlo consezvindo controlar a doenca. Segundo Barreto e Teiseira (2008) as acdes de controle evistentes, altm de custosas, thm se mostrado inefetivas. Uma vez que al informaches de combute se dirigem exclusivamente a erradicasto do vetor, com ideologias que chezam a detender a naso existencia do mosquito (conforme cartazes das campantas oficialis), o conthecimento do dido da dengue e melhores formas de

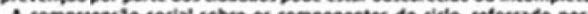

A compreensaso social wotre os componentes do cido, retorgado por informagdes

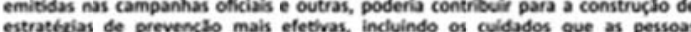
Gíagnosticadas deveriam tomar na intençao de evitar a contaminasio dos mosquitos. Sabendo-se que os mosauitos nascem descomtaminador, uma acso preventiva que poderia ter eficicia seria evitar a infecsto vetorial, por meio do isolamento dos doentes em was casas durante o periodo infectivo.

Nas se pobe prescindir do conhecimento sobre a origem da contaminasalo, segundo Teixeira $(1 \mathrm{~m})$, a inica fonte de infersaso do vetor 6 o homem, informasto esta que so eses sendo expliciada pelas campanhas onciak, informundo somente que o

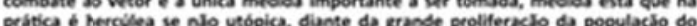

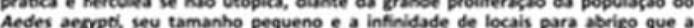
especie encontra no melo urbano.

Diante do exposto, considera-se necessirio sobrepujar o desconhecimento do ciclo da denzue pela sociedade a fim de conscientizar os cididios sobre as me thores formas de se combater a epidemia, desenvolver asbes em espases formais e nabo formuis de ensino que aprofundem o debate sobre o tema, oportunizando a realizaclo de asbei ponitivas voltadas para formas de controle que compatbilitem o respeito a questode: recials, so

Oautrivos

Construir em conjunto com os partikipantes do projeto melhores formus de combate - prevensto da dencue; levantar as origens e principais infulndeiss sobre os contecimentos dos alunos participantes sobre a tembitica; desvelar as ideoloplas que epidemia; informar aos óresos competentes os resultadoi da pesquilis com a intencato de contribuir a combate a dencue e promover a participarsa didads e sustentivel

Materias e MtTodoos

O projeto inkiclov em mailo e finalicarb em setembro de 2016 e envolveu as turmas de

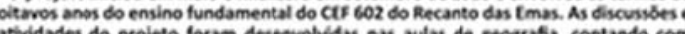

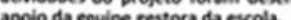

Desouls de mestrado do Centro de Desenvolvimento

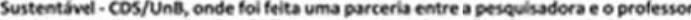
recente, sendo a primeira bioloca e o segundo geobrato, constituindo uma

Foram desemvolvidas ate o presente nove asbes (sendo a úttims prozramado para setembro de 2016) que envolveram aplicasto de questionsirios, sulas expositiva

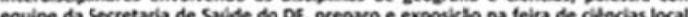
equipe da secretaria de sach
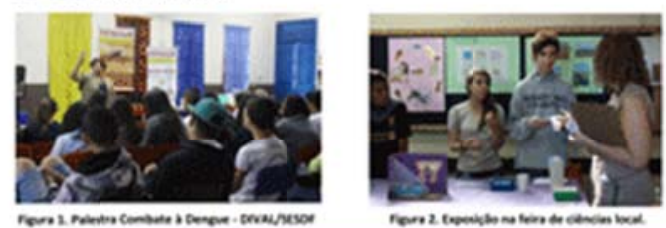
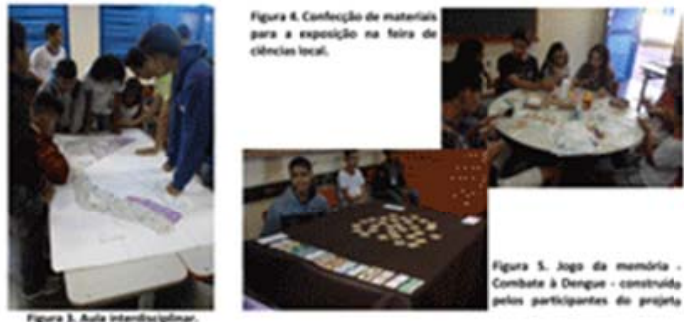

Resuttadios

Os dados revelaram que as informasdes sobre a temstica do projeto of fortemente influenciada pelas campanhas osciais ce combute e erradicaraso da dencué, que por sua controle da epidemia.

As attividades explicitaram que existiu um desconhecimento significativo dos participantes sobre o ciclo da dencue e que fol superado pela maloria a partir dos

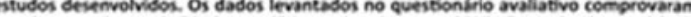
que de um universo de 78 alunos, 67 (aproximadamente $26 x$ ) ndo conheciam o ciclo da

Ademais, o questiondrio diagndstico revelow que a ideia principal trarida pelos alunor

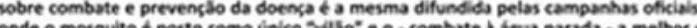
unica forma de secosto como inco

Um dado alarmante se referiv ao desconhecimento por parte dos alunos e att meimo de atcuns semidores (que participaram indiretamente por meio de convertios informalis, sobre a contaminaslo do mosquito. Observou-se surpress ao saberem cove os mosevitos e que se contaminam ao picarem pessous doentes, com excesjo d. transmissto vertical (transovariana), a intormagto bisica de que sto as pessoas contaminadas que transmitem os sorotipes da dengue ass mosquitos era entso Aesconhecida parab, 2 N dos alunos.

iptese do projeto, de que as campanhas officisis informasdes passadas para a populasta, o que obsurece considera-se que therecombute.

parar a doentes que adotem medidas preventivas tos se contaminem, como o uso de telas contra insetos em inclusto de alimentos ricos em vitaminas do compleso 8 associads a outras recomindescts, evitar exponiks a a morquitor, etc.

- projeto contrisuiv com a conscientiasajo dos participantes sobre posturas mais

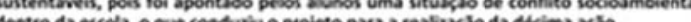

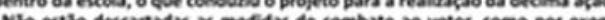

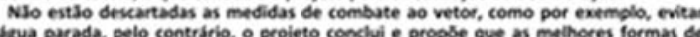
prevenglo devem considerar as duas formas de interrupsalo do ciclo da dencue. consiotracoes hinaIs

Os dados comprovam a necevidade de ampliaslo dos connecimentos sobre o ciklo do dentue; as campanhas oficials de combate podem ser melhoradas no pue fia respeito competentes uma revislo sobre a ideolocia da nlo existincis de ums espotcie dos ecosistemas presente em cartares de campanhas; a forma mais completa de combate Sepidemia deve comsiderar tanto a transmissilo dos sorotipos da doensa a monevilto vetor como o combate an mesmo; fol encaminhado um relatbrio com os dado: preliminares do projeto ass setores competentes do Ministerio da Saude e Viglilincia um joto da memoris segundo as concepples do projeto.

Rertrencias

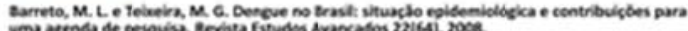

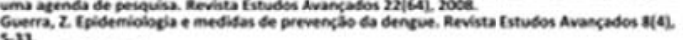

intormacho Eletbinica:

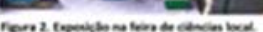

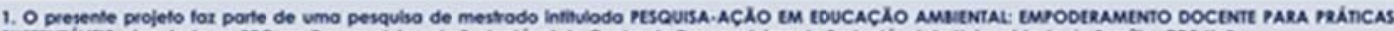

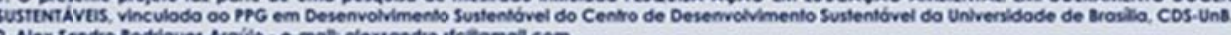
2 Alex Sondro Rodilgues Aroujp- - e-mokik dexsondrastetemoll com

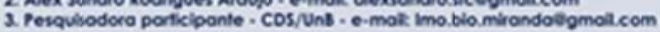

Figura 19: Banner do projeto exposto no Circuito de Ciências Regional. Fonte: Elaborado pela comunidade investigativa, revisão Dr. Carlos Saito. 
Ao longo das atividades do circuito, os alunos demonstraram grande satisfação em participar. A possibilidade de assistir apresentações de outros grupos, de alunos de outras escolas da cidade, enriquece a visão dos envolvidos e oportuniza a troca de experiências e saberes, favorecendo processos educativos.

Dentre os trabalhos exposto pelas escolas, um grupo também dedicou suas investigações ao combate à dengue. Pela correlação da temática, os alunos e a comunidade investigativa compararam os objetivos dos trabalhos e verificaram que a outra escola absorveu as ideologias das campanhas oficiais de combate à dengue e as aplicou dentro do espaço da escola, buscando erradicar locais que poderiam acumular a água parada, na concepção de que somente o vetor deve ser combatido. Nas reflexões subsequentes, a hipótese do trabalho mais uma vez era confirmada, acentuada pela falta de reflexão dentro do ambiente escolar.

No período vespertino ocorreram as avaliações do projeto. Os alunos e a comunidade investigativa constataram que os avaliadores desconheciam o ciclo da doença. Um dos avaliadores demonstrou grande interesse pelo projeto revelando que gostaria de ler os resultados finais, pois na data da exposição o último ciclo não havia ocorrido, os dados expostos eram preliminares.

As atividades do penúltimo ciclo se encerraram no período noturno, com boas impressões dos visitantes e do grupo participante. No mês subsequente ao circuito regional de ciências, os alunos envolvidos receberam na escola um certificado de participação fornecido pela SEDF, positivamente percebido em algumas falas discentes “foi o primeiro certificado da minha vida", incentivando a participação.

\subsubsection{Décimo ciclo - Mutirão Socioambiental}

O planejamento do décimo ciclo (figura 21) da pesquisa-ação em educação ambiental delimitou duas principais ações: a apresentação dos dados do questionário avaliativo e, a partir desta ação a realização de um mutirão socioambiental cuja finalidade seria a organização do mobiliário depredado pelos alunos protegidos das chuvas para diminuir as possibilidades de criadouros de mosquitos no local. 
Plano de Aula - Décimo Ciclo

\section{Projeto Combate à Dengue}

Ação: Mutirão Socioambiental.

Disciplina: Geografia Público envolvido: alunos dos oitavos anos

1. Objetivos: realizar uma ação positiva para o conflito apontado pelos alunos participantes do projeto com a intenção de despertar consciência sobre respeito ao patrimônio público e meio ambiente; explicitar aos participantes as relações da ação com a sustentabilidade.

\section{Conteúdo(s):}

- Ciclo da dengue e formas de prevenção; sustentabilidade; respeito ao patrimônio público e meio ambiente.

3. Materiais: data show; quadro negro; alunos e servidores voluntários;

4. Procedimentos

- Primeira aula:

$\checkmark$ Apresentação da tabulação do questionário avaliativo preenchido pelos discentes contextualizando com temas relacionados à sustentabilidade; levantamento dos voluntários para participar do mutirão.

- Segunda e terceira aula: realização do mutirão de organização das cadeiras e carteiras acumulados na escola fruto de ações de depredação dos alunos.

Será feita uma separação do material por modelo para facilitar o recolhimento pelo caminhão da CRE Recanto das Emas.

\section{Avaliação.}

Figura 20: Planejamento décimo ciclo.

Fonte: Elaborado pela comunidade investigativa.

Para o proposto, utilizou-se slides com quadros das tabulações das respostas dadas no questionário avaliativo. À medida que os dados iam sendo expostos ocorreram discussões sobre os mesmos. A cobrança por parte dos alunos para o desfecho dos debates, especialmente a resolução do conflito socioambiental era constantemente lembrada.

A comunidade durante o planejamento do último ciclo refletiu a importância de se destacar, mesmo que em pouco tempo, as concepções reveladas no questionário avaliativo a respeito do descarte de resíduos sólidos no lixão da Estrutural. Na percepção de Freire (1968) precisamos estar convencidos de que a visão humana do mundo, que se manifesta nas várias formas de sua ação, reflete a sua situação no mundo.

Era necessário imprimir as relações entre ação e consciência, na medida em que uma legitima a outra, e ambas constituem a realidade. Para problematizar a situação e instigar a reflexão dos alunos, foram expostas imagens (figura 21) de trabalhadores no 
lixão da Estrutural e lançada a frase provocadora: para você a existênncia de lixões é uma boa medida de destino aos resíduos sólidos?

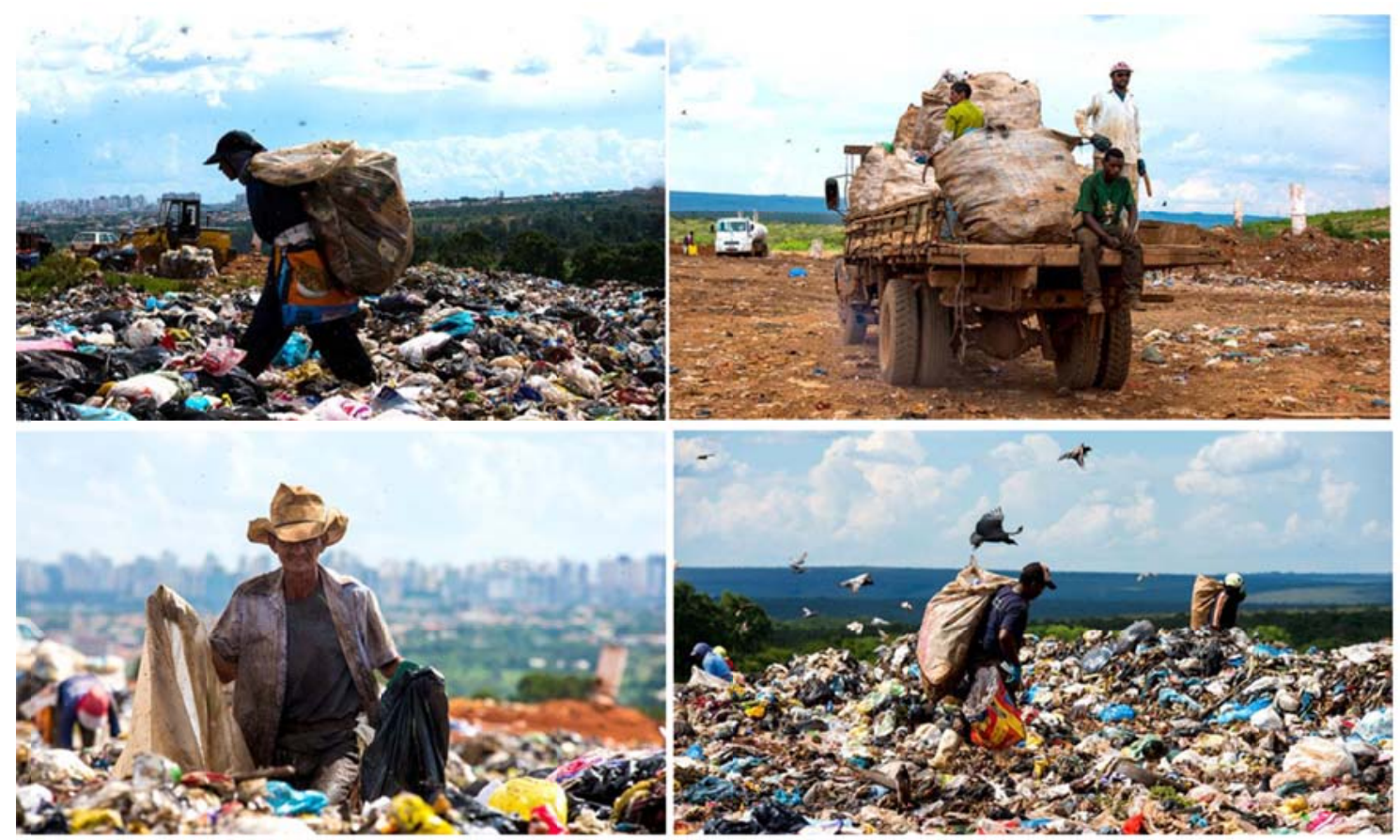

Figura 21: Imagens provocadoras do Lixão da Estrutural para a reflexão a respeito da existência de lixões. Fonte: Paula Fróes, BBC Brasil.

http://www.bbc.com/portuguese/noticias/2016/03/160310_galeria_lixao_estrutural_pf.

Unido à apresentação das imagens, conhecimentos sobre a proibição legal de depósitos a céu aberto, trabalho infantil, direitos trabalhistas, salubridade, eram acrescidas às discussões na intenção de esclarecer os pontos negativos de se conceber a existência dos depósitos a céu aberto como medida para a problemática do descarte de resíduos sólidos. Os alunos demonstraram que compreendiam o exposto, porém a mudança da concepção não pode ser verificada categoricamente, dada a finalização do projeto.

O quadro 4 que compilou as informações coletadas pela comunidade investigativa foi exposto no final da apresentação o que deu visibilidade às instâncias envolvidas e o contexto do conflito socioambiental para os alunos. $\mathrm{Na}$ observação participativa a comunidade percebeu que nem sempre todas as partes envolvidas em conflitos que ocorrem na escola são consultadas, possivelmente desconhecidas, o que potencializa compreensões deturpadas ou incompletas das situações, precarizando a resolução do conflito.

O resumo do quadro 4 gerou a figura 22 , ponto que apoiou a comunidade investigativa unida à direção da escola a convidar cinco alunos de cada turma de oitavo 
ano a participar da última ação da pesquisa-ação educativa desenvolvida: o mutirão de organização.

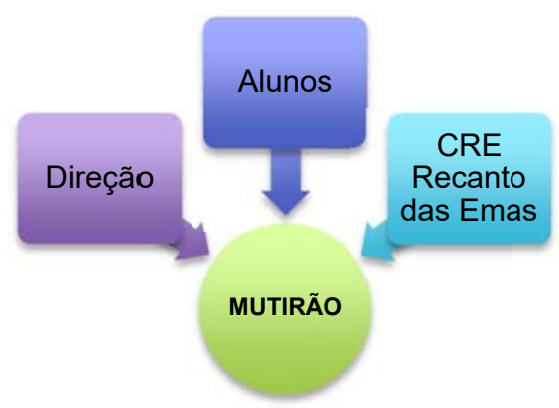

Figura 22: Convergência dos setores consultados sobre o conflito socioambiental. Fonte: elaboração própria.

Em cada turma convidada, o voluntariado discente ultrapassou a quantidade de vagas oferecidas, demonstrando que a ação proposta embora envolvesse esforço físico e que aparentemente não era atribuição dos alunos, quando contextualizado, fica explicito que o problema é de todos, desconstruindo concepções de que o trabalho é somente da equipe de limpeza escolar.

No dia 28/09/2016 ocorreu o planejado mutirão. Alguns alunos pré-selecionados não estiveram presentes no dia, e diante do fato outros alunos pediram para participar, em um total de vinte e cinco alunos, conduzidos por um funcionărio da empresa contratada para serviços gerais, além da comunidade investigativa.

A diretora da escola deu as orientações iniciais ao grupo, que ao longo de 60 minutos concluiu a ação. Durante a atividade a única reclamação registrada foi por parte de três alunos que não gostaram de ter sujado as suas roupas, a atividade ocorreu de forma amistosa e colaborativa.

A CI percebeu que alguns alunos que apresentaram problemas de comportamento em sala de aula durante o mutirão, desempenharam conduta positiva e responsável, em um caso observou-se um perfil de liderança ao organizar a logística de separação dos materiais entre os colegas.

Finalizada a organização, a comunidade em roda, conversou com os participantes do mutirão reafirmando a necessidade da não depredação de patrimônio público, buscando ouvir dos alunos as suas concepções a respeito da atividade. Os alunos que se expressaram, de forma resumida revelaram que é melhor cuidar para evitar que a situação volte a acontecer e coloque em risco a saúde de todos. Seguindo o 
planejamento da ação, a comunidade entregou um certificado de participação aos envolvidos como incentivo a postura cidadã e amiga do meio ambiente.

O último ciclo permitiu conferir que a hipótese e os objetivos da pesquisa-ação foram comprovados e atingidos respectivamente, porém, o alcance não significou para a comunidade investigativa que outras problematizações seriam necessárias, dentre elas, destacam-se:

i) as relações entre o aumento da epidemia justamente em estados, bairros e setores mais pobres do Brasil;

ii) ii) a permanência do uso de fumacês por malathion, e outros químicos, mesmo comprovada a resistência progressiva do vetor aos pesticidas e seus malefícios à saúde humana;

iii) iii) o relacionamento duvidoso do MS aos casos de microcefalia em bebês recém-nascidos em regiões pobres do país que, coincidentemente, dezoito meses antes das notificações, receberam o veneno pyroproxyfen (inibidor da maturação do vetor) na água potável das populações;
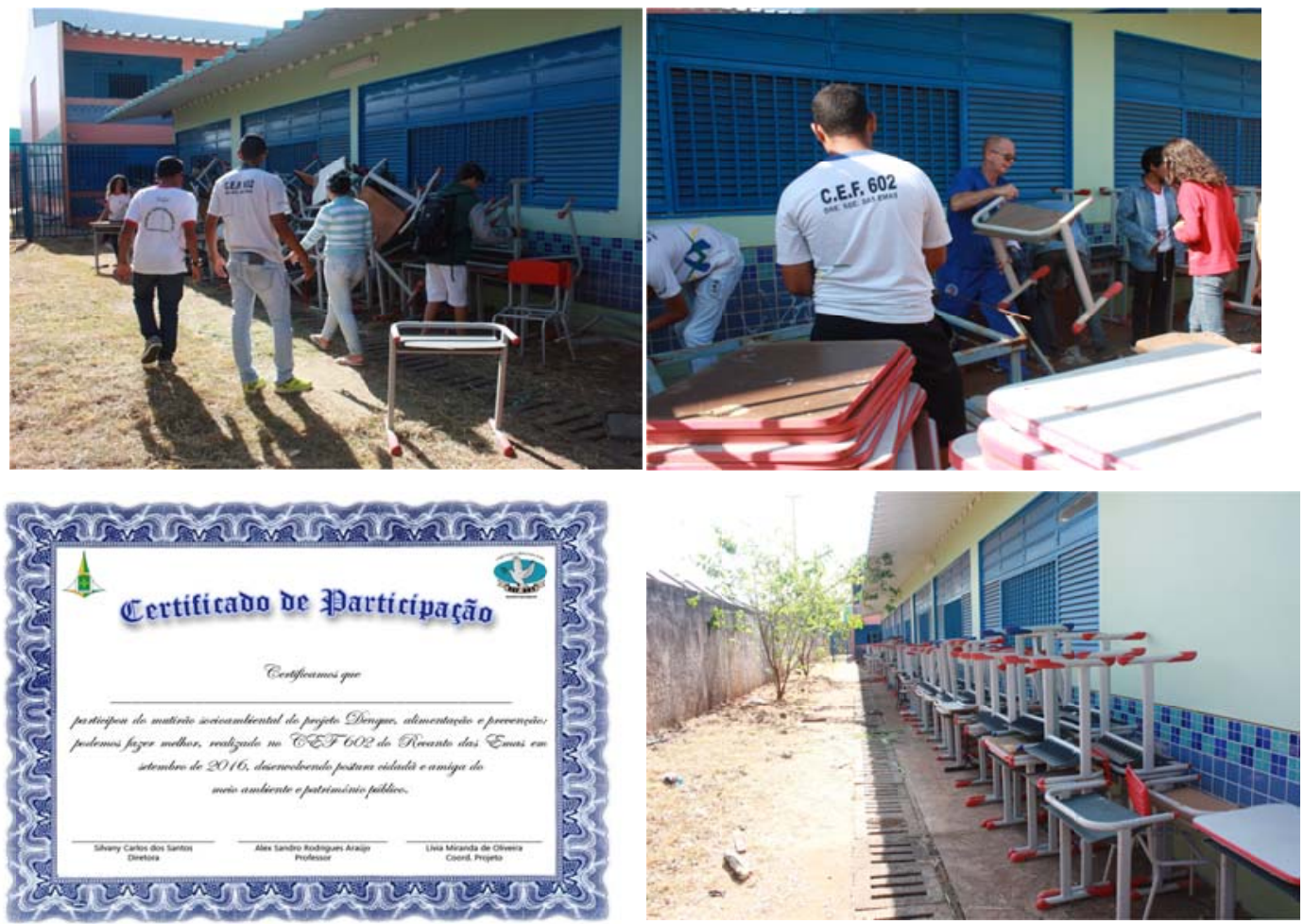

Figura 23: Mutirão socioambiental e certificado entregue aos alunos e servidor participantes Fonte: Lívia Miranda de Oliveira. 


\subsection{Registros auto-reflexivos do professor regente}

Antes de iniciar a pesquisa in loco, um registro auto-reflexivo a ser escrito pelo participante que constituiria a comunidade investigativa foi selecionado como o instrumento a ser aplicado para os registros individuais os quais seriam posteriormente submetidos à análises de conteúdo de Bardin (2011). A decisão de utilizar o instrumento surge da necessidade de dar visibilidade às possíveis mudanças de práxis docente que configurassem empoderamento.

Em paralelo às atividades desenvolvidas no projeto, foram preenchidos quatro registros auto-reflexivos pelo professore regente, em espaços de tempo diferentes entre os meses de maio a setembro. Para cada registro foram colocadas questões norteadoras, descritas no quadro 5, buscando assegurar que determinados temas fossem citados.

\begin{tabular}{|c|c|}
\hline $\begin{array}{c}\text { Registro } \\
\text { auto-reflexivo }\end{array}$ & Questão norteadora \\
\hline 1 & $\begin{array}{l}\text { Estimado professor, registre nas linhas a seguir as suas principais } \\
\text { reflexões, críticas e/ou sugestões a respeito de sua prática docente } \\
\text { incluindo os possíveis entraves para o seu bom desenvolvimento. }\end{array}$ \\
\hline 2 & $\begin{array}{l}\text { Estimado professor, registre nas linhas a seguir as suas principais } \\
\text { reflexões, constatações a respeito de sua prática docente incluindo os } \\
\text { possíveis entraves para o seu bom desenvolvimento. Essas reflexões } \\
\text { surgiram ao longo do trabalho em parceria com a pesquisadora Lívia } \\
\text { Miranda ou são constatações anteriores? }\end{array}$ \\
\hline 3 & $\begin{array}{l}\text { Estimado professor, com relação aos planos de aula construídos ao } \\
\text { longo do projeto, registre as suas principais reflexões sobre o efeito na sua } \\
\text { atuação profissional. Você já fazia antes? Pretende continuar fazendo esses } \\
\text { planos? O que você mudaria neles? }\end{array}$ \\
\hline 4 & $\begin{array}{l}\text { Estimado professor, registre nas linhas a seguir suas reflexões } \\
\text { relacionadas à participação do pesquisador (Lívia Miranda) ao longo do } \\
\text { projeto. O projeto desenvolvido em parceria com a pesquisadora Lívia } \\
\text { Miranda lhe trouxe benefícios? Se possível destaque os pontos positivos e } \\
\text { negativos dessa atuação em conjunto. }\end{array}$ \\
\hline
\end{tabular}

Quadro 5: questões norteadoras dos registros auto-reflexivos.

Fonte: elaboração própria. 
A ideia de que o instrumento auto-reflexivo aplicado garante todos os conhecimentos pertinentes à pesquisa não existiu na concepção do pesquisador. A escolha e aplicação do instrumento buscou assegurar por escrito algumas autoconcepções a respeito da práxis do professor docente e possíveis influências da pesquisa-ação educativa nesta, além dos possíveis entraves, as contribuições da parceria professor regente/pesquisador e os planos de aula.

Acrescidos aos registros escritos foram considerados os momentos de reflexão da comunidade investigativa nos períodos das coordenações pedagógicas (pois ocorreram de forma dialógica e natural, havendo mais confiança e liberdade de expressão por parte do professor regente) para as análises e inferências finais de pesquisa.

Ao longo da observação participante o pesquisador percebeu que no registro auto-reflexivo as falas do professor regente foram mais contidas, possivelmente pela formalização do instrumento que colheu inclusive a sua assinatura, mas que associadas às falas e reflexões em cada ciclo da pesquisa-ação ganharam contornos mais explícitos.

Como realizado anteriormente nos dados dos questionários, os quatro registros auto-reflexivos foram lançados inicialmente no sítio Tagul.com para buscar luzes sobre palavras indicadoras que poderiam constituir as categorias de análise de conteúdo.

Para Bardin (2011) todas as palavras do texto podem ser levadas em consideração podendo fazer-se a distinção de palavras plenas das palavras vazias. A mesma distinção comentada pela autora foi adotada, excluindo-se palavras vazias de significados, como as classes gramaticais das preposições, artigos, conjunções, pronomes e alguns numerais. Desta forma a figura 24 ilustra a nuvem de palavras gerada. 


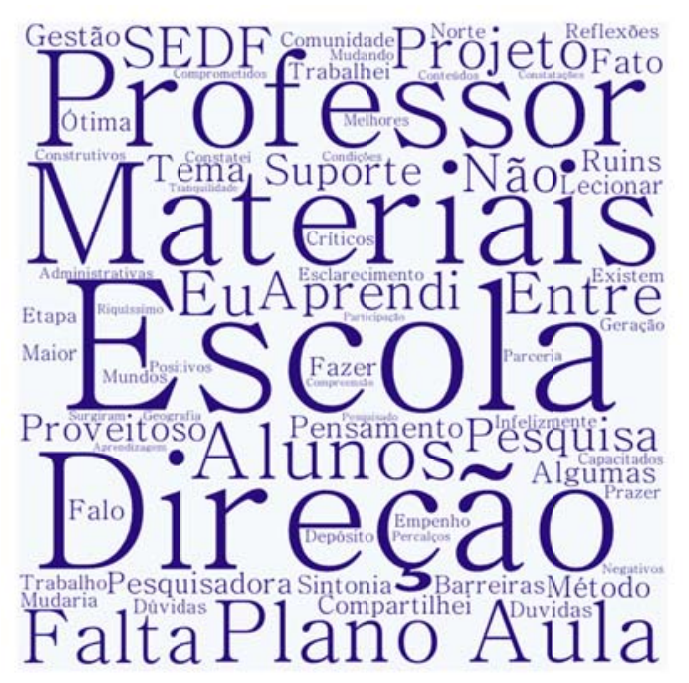

Figura 24: Nuvem de palavras resultante da união dos quatro registros auto-reflexivos. Fonte: elaboração do autor utilizando o site Tagul.com.

Os termos escola, professor, direção, materiais, planos e aula ocorreram com maior frequência, e pelo mesmo motivo tornam-se os indicadores das análises para a criação de categorias. É fato que os termos surgiram das questões provocadoras, que juntas constituíram quatro núcleos reflexivos: i) a sua prática docente, ii) entraves possíveis para a prática docente, iii) a parceria/atuação com a pesquisadora e iv) o efeito dos planos de aula na atuação profisssional.

No primeiro núcleo, a prática do docente, buscou-se estimular o exercício de reflexão da própria prática, para garantir os momentos de auto-reflexãio. Os relatos do professor regente foram genéricos, colocando os professores das escolas públicas como principal sujeito. Na compreensão de que ele próprio compõe este grupo, reflete-se que as colocações são também auto-reflexões sobre suas práticas pedagógicas.

As falas registradas mostraram que o professor regente considera o grupo ao qual ele pertence como capacitado, com pensamento crítico e comprometido. A autoreflexão coletada pelo instrumento demonstrou que apesar de capacitado para a docência, o professor regente destaca a importância de mudar a metodologia de ensino adotada, na transição para modalidades que promovam as aprendizagens não somente de seus alunos, mas de professor e alunos.

“os professores da SEDF são bastante capacitados para lecionar para seus alunos”.

“o corpo docente que está entrando nas escolas públicas está com pensamentos construtivos e críticos, com ideias novas, uma nova geração de professores comprometidos”. 
“Iria acrescentar mais métodos pedagógicos relacionado com a disciplina de geografia e mais vídeos, programas para auxiliar o professor e alunos na aprendizagem”.

A última declaração explicita que os momentos de auto-reflexão inseridos em processos de pesquisa-ação contribuem para a democratização do ensino e das aprendizagens, na medida em que possibilitou ao professor regente uma relação horizontalizada das aprendizagens conjuntamente com os seus alunos, isto é, ele concebe que pode aprender com, aprender no processo, aprender e ensinar, não somente ensinar e os alunos aprenderem.

Metodologias interdisciplinares, que respeitam a pluralidade de concepções e horizontaliza os conhecimentos são mais adequadas à educação ambiental conforme os documentos construídos ao longo dos variados encontros, debates e produções nacionais e internacionais (Declaração de Estocolmo, 1972; Carta de Belgrado, 1975; Declaração da Conferencia de Tibilisi, 1977; Declaração de Tessalônica; PNEA, 1999).

O segundo núcleo pesquisado por meio dos registros auto-reflexivos verificou os entraves possíveis para a prática docente. Este campo foi propulsor para a percepção de que é necessário ultrapassar a constatação de problemas/entraves da práxis docente pelo próprio professor, sob os auspícios de que a mera constatação não resolveria as situações vividas. Os principais entraves registrados pelo docente incluíram:

“Falta muita “mão de obra” que são os professores”.

“Falta de materiais didáticos em algumas escolas”.

“Falta de uma gestão entre escolas ou SEDF”.

“Falta de empenho de alguns gestores dentro da escola”.

“Algumas escolas que eu já trabalhei a gestão tinha uma ótima sintonia, e nas outras escolas parecia um “depósito de alunos”.

“Infelizmente existem esses dois mundos nas escolas públicas do DF”.

"Mais para que ambos caminhem no mesmo sentido a escola onde o professor trabalha tem que lhe dar bastante suporte como: melhores condições de trabalho, materiais pedagógicos, mapas atualizados, salas bem conservadas e arejadas, sintonia entre direção, alunos e professores, etc”.

Considerando o número de repetições de cada palavra das frases acima, as mais frequentes e com significação pertinente à investigação foram escola, falta, professor, materiais e gestão. Tomando-as como indicadores, formaram-se duas categorias para 
análise de conteúdo: i) Faltam professores e materiais nas escolas, ii) Falta gestão nas escolas.

Na primeira categoria, o conteúdo destaca o desfalque do quadro de docentes nas escolas públicas do DF que atrapalha diretamente a comunidade escolar uma vez que as lacunas das disciplinas ministradas prejudicam o desenvolvimento de atividades interdisciplinares e do currículo da educação básica como um todo. Além da falta de professores, a primeira categoria cita a falta de materiais nas escolas.

Os materiais envolvidos correspondem a todo o tipo de instrumentalização que poderia contribuir para as atividades de ensino e aprendizagem tais como o livro didático, mapas, televisores, hardwares, softwares, salas de aula arejadas, etc.

A segunda categoria construída diz respeito à gestão das escolas públicas, que por sua vez estão mais voltadas para as figuras do diretor e do vice-diretor. Embora a categoria criada tenha expressado a frase "Falta gestão nas escolas", não significou a sua inexistência, mas um descolamento das atribuições inerentes aos cargos às ações praticadas.

Observou-se que os entraves descritos (alguns vivenciados pela comunidade investigativa) estão ligados aos serviços que deveriam ser realizados pela equipe gestora. Quando a questão envolve a falta de materiais didáticos, sabe-se que anualmente as escolas públicas do DF recebem verbas que podem ser programadas para a aquisição de materiais permanentes e de consumo. Para este ponto a organização e programação financeira da escola deve ser dada pela equipe gestora. Percebe-se que uma parte das unidades escolares a programação, manutenção e atualização de acervos pedagógicos é desorganizada.

A crítica apontada pelo professore regente partiu de suas observações na prática, uma vez que este relata já ter trabalhado em escolas da mesma rede nas quais o trabalho, organização e medidas protetivas de patrimônio das equipes de direção evitou a carência de materiais pedagógicos.

No terceiro núcleo de investigação dos registros auto-reflexivos foi colocada a questão da parceria/atuação com a pesquisadora. Sobre esse assunto o professor regente revelou que suas reflexões sobre o que já havia praticado até o momento do projeto foram mais profundas. Esta percepção surgiu do exercício da espiral cíclica da pesquisaação, que deteve momentos reflexivos e auto-reflexivos em cada ciclo realizado. Em se tratando do projeto Combate à Dengue, dez ciclos foram realizados e refletidos 
sistematicamente, não obstante os momentos de reflexões individuais diacrônicos ao cronograma de projeto.

Como o terceiro registro ocorreu nos ciclos finais da pesquisa, o professor regente relatou os "percalços ruins até chegar na etapa final do projeto" mas que observando sua prática e a incorporação do perfil de investigador ativo, não foram suficientes para o encerramento ou anulação das etapas propostas. O que seria para Carr e Kemmis (1986) como uma finalidade da pesquisa-ação educacional: a melhoria da prática por meio da reflexão e auto-reflexão das ações praticadas junto ao seu contexto.

A exemplo disto, o último ciclo correu o risco de não ser realizado, dado o encerramento do prazo de coleta de dados da pesquisa e a constante modificação da data do mutirão pela diretora da escola, que por três vezes consecutivas e motivos individuais anulou a data de execução da ação.

Para a pesquisadora a ação poderia ser cancelada, e o último ciclo conteria somente a apresentação dos dados finais aos alunos. A concepção da pesquisadora partiu da observação de que o projeto obteve alcance satisfatório sobre seus objetivos, além da percepção de que nem sempre o planejamento (por mais coerente que seja) acontece, pois não existe controle total de ações planejadas em contextos sociais como a escola.

Em contraste com o posicionamento da pesquisadora, o professor regente defendeu a permanência do primeiro planejamento e a execução do mutirão socioambiental, afirmando que o trabalho prévio poderia ser enfraquecido se a ação não fosse executada.

A realização do mutirão era, indubitavelmente, a ação mais adequada à educação ambiental, pela possibilidade de praticar uma ação positiva, desta forma, coube ao professor regente uma última conversa com a diretora enfatizando-se que sua ausência não impediria a realização da ação, mas que seria uma chance pertinente da gestora participar das discussões sobre respeito ao patrimônio público, necessidade outrora revelada por ela mesma. Esta por sua vez, encontrou uma data e participou do início do mutirão.

O professor regente relatou que a participação da pesquisadora no projeto foi bastante interessante, riquíssima e proveitosa. Além da participação, a parceria instituída permitiu que o professor, segundo suas palavras, aprendesse e compartilhasse pensamentos e ideias, que foi riquíssimo não somente para ambos mais para os alunos. 
Dito isto, os relatos do docente encerraram afirmando que foi possível tirar dúvidas sobre os temas trabalhados (a esse respeito o professor regente durante os momentos de reflexão da comunidade revelou que não sabia que o mosquito nascia descontaminado) e que foi possível levar mais conhecimento não só para os alunos como para suas famílias e toda a comunidade. Carr e Kemmis reforçam que

O sucesso do trabalho como amigo crítico pode ser medido pela extensão de sua ajuda aos envolvidos no processo educacional para melhorar sua propria prática educacional, suas próprias compreensões, e as situações e instituições nas quais ele trabalha (Carr e Kemis, 1986, p. 161).

Verifica-se nesta altura, o que os mesmos autores pontuaram sobre a parceria pesquisador/professor regente que, ao ser constituída, desenvolve-se um relacionamento colaborativo no qual o pesquisador se torna um amigo crítico que ajuda os envolvidos com conhecimentos para agir mais prudentemente, sabiamente e criticamente, nos processos de transformação educativa.

O quarto e último dos registros auto-reflexivos investigaram a postura do professor regente frente aos planejamentos de aula construídos a partir da observação da prática e de momentos de reflexão.

Inicialmente o professor regente relatou que adota os planos para suas aulas, sob a justificativa de que "é um método para o professor ter um norte um rumo, para o professor inserir seus conteúdos com maior tranquilidade para seus alunos", adiante o professor regente afirmou "pretendo continuar com os planos de aulas, em cada série do ensino fundamental e médio, quando você trabalha em escolas particulares é obrigatório o professor fazer seus planos de aulas".

Percebeu-se que os planos de aula referidos pelo professor correspondem às muitas elaborações da profissão docente, indistintamente de serem aplicados em turmas da rede de ensino pública ou privada, e que geralmente não sofrem o burilamento da reflexão. $O$ exercício de observar a ação para refleti-la e só depois tecer o novo planejamento, ou um replanejamento, não era conferido na prática do professor regente segundo relatos nos momentos de reflexão da comunidade investigativa. 
Os planejamentos das aulas de geografia do professor consistiam em programas mensais e até bimestrais de conteúdos, ações e avaliações que mecanicamente reduziam e pré-fixavam as atividades da disciplina.

O que se pode afirmar é que após a realização da pesquisa-ação em educação ambiental, o professor regente passou a conhecer uma nova abordagem teóricometodológica que elabora planejamentos e ações de acordo com o desenvolvimento e reflexão das atividades propostas, aberto à participação dos alunos, o que fortalece a discussão, problematização e o envolvimento de temáticas afins e/ou temas geradores pertinentes.

A conjunção dos ciclos realizados na pesquisa apresenta-se na figura 25 que descreve em cada quadro o número e as principais ações e observações participantes, nas setas da direita (lilás) as fases de reflexão e nas da esquerda (verde) os planejamentos da pesquisa-ação em educação ambiental, onde a cada volta concluída tornava-se mais familiar à CI a prática do planejar, agir/observar, refletir, e a percepção de que sua adoção potencializa mudanças da práxis docente.

É importante ressaltar que, apesar da figura 25 aparentar que os ciclos sequenciais são iguais entre si, trata-se apenas de uma simplificação gráfica, pois os ciclos espiralados de uma pesquisa-ação não são regulares e semelhantes entre si. Inclusive, este conjunto de ciclos representa um nível hierárquico superior, que vem a ser detalhado num nível hierárquico inferior conforme Berlinck e Saito (2010). A depender da dinâmica de observação dos resultados de um ciclo, sua avaliação e replanejamento, o ciclo seguinte inicialmente planejado pode não ocorrer ou sofrer ajustes, de forma dinâmica no decorrer da pesquisa-ação. Em alguns a ação de planejamento exige um esforço maior, em outros a execução é mais prolongada, ou a avaliação dos resultados observados demanda mais tempo, alongando a alça da espiral que fica então “deformada" em sua regularidade aparente. 


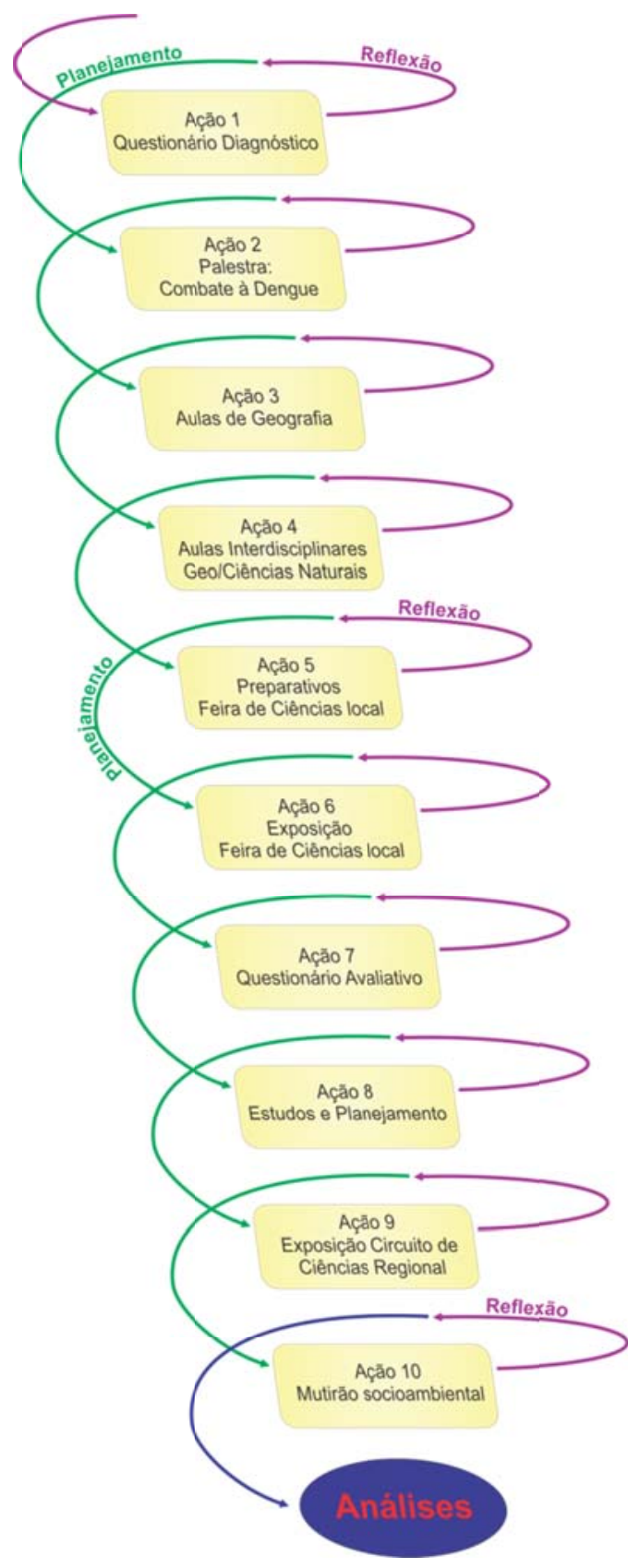

Figura 25: Compilação das dez espirais cíclicas do estudo de caso. Fonte: elaboração própria. 


\section{CONCLUSÃO E RECOMENDAÇÕES}

A preocupação ambiental como um paradigma social nos anos 70 conduziu a humanidade a perceber que as questões sociais e econômicas seriam indissociáveis às preocupações já existentes, emergindo a sustentabilidade como novo campo a ser buscado tendo a educação ambiental e práxis docente elemento relevantes para o esforço.

A situação vivida impulsionou o presente estudo, que se propôs a investigar a adoção teórico-metodológica da pesquisa-ação (Carr e Kemmis, 1986) em educação ambiental para promover empoderamento docente na busca de práticas mais sustentáveis. A atividade fim da PA é a transformação social, e para tanto seguiu-se a organização heurística com momentos de planejamento, ação/observação e reflexão, da espiral cíclica (Lewin, 1946) da pesquisa-ação educacional.

Como ponto de partida formou-se uma comunidade investigativa que desenvolveu em uma escola da rede pública de ensino do Distrito Federal pesquisa-ação em educação ambiental, averiguando ao longo do processo momentos de fortalecimento docente que configuraram o que Friedmann (1992) denomina empoderamento.

As análises justificaram a adoção teórico-metodológica da pesquisa-ação e sua espiral de fases para atingir e modificar a práxis docente. Ao longo do projeto desenvolvido verificou-se que o professor regente refinou o olhar para questões socioambientais, adotou conduta e visão docentes mais acessíveis, dialógicas e investigativas a temas geradores, em desapego aos planejamentos bimestrais estabelecidos previamente.

Com base nas experiências e esforços vivenciados pela pesquisa, a comunidade alcançou o movimento de planejamento conjunto de ações pedagógicas com os discentes, comprovando que é possível horizontalizar os momentos de construção para uma prospecção mais democrática e coletiva.

As vias percorridas ampliaram a visão do professor regente e dos discentes sobre as hierarquias do serviço público e suas relações com as atividades desenvolvidas na escola, desvelando para o primeiro as relações de poder que verticalizam e limitam as ações educativas (Friedberg, 1993). Associado a isto, verificou-se que o perfil de professor-investigador empoderou a práxis docente para superar tais relações. 
A reflexão da prática explicitou à comunidade que as atividades educativas mais do que descodificar conteúdos, necessitam de enfoque dialético, dinâmico, interativo, complexo de uma realidade que não está dada, mas que está em permanente desconstrução, construção e reconstrução pelos atores sociais (Colmenares \& Piñero, 2008). Quando se almeja a adoção de sustentabilidade no comportamento humano, torna-se imprescindível uma revolução teórica e da prática docente investigativa, dialógica e problematizadora que incorpore conteúdos formativos, temas geradores, detecção de conflitos e ações positivas, retroagindo na realidade vivida para tornarem-se social e ambientalmente úteis (Freire, 2011; Carr e Kemmis, 1986; Saito, 2012).

As dificuldades, no entanto, presentes entre professores e direção da escola que por determinadas vezes não permitiram que mudanças na estrutura organizativa das aulas ocorressem. Mesmo sentindo a contradição do que seria o ideal versus a realidade, e que as dificuldades tenham demandado esforços exaustivos da CI, comungou-se da acepção de Lewin (1958) que para se conhecer algo é preciso tentar mudá-lo, configurando os entraves como elementos para transformação.

Outro fator desafiador ao projeto consistiu nas mudanças constantes do calendário escolar que por vezes incontáveis, praticamente a cada quinzena, reestruturou o cronograma de pesquisa. Este elemento é observado com frequência por aqueles que atuam na educação em especial nas escolas públicas, constituindo um desafio para o planejamento de ações.

É categórico afirmar que os momentos de construção e reconstrução vividos pela CI contribuíram para que o professor regente e seus alunos incorporassem atitudes mais próximas da meta estabelecida para a EA na Carta de Belgrado. Mais ainda, pode-se dizer que a pesquisa-ação desenvolvida convergiu para os referenciais indicados anteriormente, especialmente Carr e Kemmis, 1986; Freire, 2014; Friedmann, 1992; Grun, 1996; e Saito, 2006 e 2012.

Conclui-se, portanto, que a execução da pesquisa-ação contribuiu para o empoderamento da comunidade investigativa em especial, pelo papel de amigo crítico desempenhado pelo pesquisador. A parceria instituída neste estudo contribuiu significativamente nos momentos de reflexão com conhecimentos para um agir de forma mais prudente, sábio e crítico, nos processos de transformação educativa. 
Dentre as atitudes verificadas no professor regente da escola, destacam-se a abertura do mesmo para execução da PA em EA, o planejamento participativo, as inúmeras pesquisas e reflexões individuais e coletivas, a investigação e busca de melhorias em níveis hierárquicos trabalhistas, a divulgação das atividades para a comunidade como um compromisso ético e social, o compromisso ético de mudar a realidade local na tentativa de incorporar ao PPP da escola a questão da conscientização sobre patrimônio público, o encaminhamento dos resultados preliminares para autoridades envolvidas no sentido de saltar escalas, a incorporação do perfil de pesquisador que empoderou a práxis docente.

Destarte é importante elencar algumas atitudes tomadas pelos discentes que corroboram a meta da Carta de Belgrado, dentre elas o despertar do olhar para conflito socioambiental, o engajamento em processos investigativos a cerca de sua realidade, o comportamento favorável à prática de ações positivas, postura mais consciente e cidadã diante das questões que envolvem o patrimônio público, comprometimento e preocupação com questões socioambientais buscando soluções para os problemas existentes e para prevenir novos.

Espera-se que as contribuições deste trabalho alcancem a realidade vivida nos pátios das escolas, salas de aula, laboratórios, praças públicas, qualquer que seja o ambiente crítico-reflexivo. O importante é a abertura crítica e disposição para buscar a interação dialógica, certificados de que a incorporação da pesquisa-ação alcança, modifica e empodera a práxis docente. Para mudarmos o rio (sociedade), precisamos interferir na correnteza (paradigmas) do seu curso (processo histórico). Como fazer se não quero ser carregado pela correnteza?

Por fim, algumas lições são tiradas do processo, que se traduzem nas seguintes recomendações:

i) Adoção teórico-metodológica da pesquisa-ação educacional em atividades de educação ambiental sob a perspectiva crítica-emancipadora.

ii) Oferta de cursos de formação continuada aos professores pela SEDF que incluam a pesquisa-ação em educação ambiental, 
iii) Ampliação da carga horária do curso EAL para propiciar o desenvolvimento de pesquisa-ação em educação ambiental por meio da espiral cíclica Lewiniana.

iv) A revisão da ideologia e metodologia de combate às epidemias de Dengue, Chikungunia e Zika vírus das campanhas oficiais brasileiras.

v) Incorporação e divulgação via campanhas oficiais governamentais de medidas preventivas que interrompem o ciclo da dengue na fase homem contaminado - vetor.

vi) Constituição nos espaços escolares de comunidades investigativas educativas para ampliar os conhecimentos locais sobre as epidemias de Dengue, Chikungunia e Zika vírus.

vii) Problematização e mobilização social, em espaços formais e não-formais de ensino sobre o uso e efeito socioambiental de fumacês, pulverização aérea e químicos teratogênicos em água potável como medidas combativas às arboviroses. 


\section{REFERÊNCIAS}

ABRASCO. Nota Técnica sobre microcefalia e doenças vetoriais relacionadas ao Aedes aegypti: os perigos das abordagens com larvicidas e nebulizações químicas fumacê. Fevereiro, 2016. Disponível em: https://www.abrasco.org.br/site/2016/02/notatecnica-sobre-microcefalia-e-doencas-vetoriais-relacionadas-ao-aedes-aegypti-osperigos-das-abordagens-com-larvicidas-e-nebulizacoes-quimicas-fumace/.

ADELMAN, C. Kurt Lewin and the origins of action research. Educational Action Research, v. 1, n. 1, p. 1-16, 1993.

AQUINO, M. S. As questões ambientais no cotidiano da educação básica: políticas públicas, formação de professor e organização curricular. Reunião Anual da Associação Nacional de Pós-Graduação e Pesquisa em Educação. Caxambu, Anais Eletrônicos ANPED, n. 33, 2010.

BARBOSA, L. N. H e DRUMMOND, J. A. Os direitos da natureza numa sociedade relacional: reflexões sobre uma nova ética ambiental. Estudos Históricos, Rio de Janeiro, vol. 7, n. 14, p.265-289, 1994.

BARDIN, L. Análise de Conteúdo. Lisboa: Edições 70, 2011.

BAYER, A. Argentine physicians claim Monsanto-linked larvicide is cause of microcephaly. International Journal of Human Nutrition and Functional Medicine ${ }^{\circledR}$, p. 8-9, 2016.

BAZIN, M. Ciência na nossa cultura? Uma práxis de educação em ciências e matemática: oficinas participativas. Revista Educar, Curitiba, v. 14, p. 27-38, 1998.

BAZIN, M. "Dengue", 2008.

Disponível em: http://imanentemente.blogspot.com.br/search/label/Maurice\%20Bazin.

BERLINCK, C.N. e SAITO, C.H. Action Research for Emancipation Informed by Habermas and Hierarchy of Systems: Case Study on Environmental Education and Management of Water Resources in Brazil. Systemic Practice and Action Research, v. 23, n. 2, p. 143-156, 2010.

Boobio, N.; MAtTeucci, N. e PASQUino, G. Dicionário de Política. Trad. Carmem, C. Brasilia: Editora UnB, 1ª ed., vol. 1, 1.330 p., 1998.

BORDA, O. F. La ciência y el Pueblo: nuevas reflexiones. Em Salazar, M. C. La invetigación-ación participativa. Incisos y desarrollos. Consijo de Educción de Adultos de América Latina. Universidad Nacional de Colombia. Madrid: Editorial Popular, OEI, Quinto Centenario, 1980.

BRASIL. Lei $n^{\circ}$ 9.394, de 20 de dezembro de 1996. Estabelece as diretrizes e bases da educação nacional. Presidência da República. Disponível em http://www.planalto.gov.br/CCIVIL_03/leis/L9394.htm 
Lei $\mathrm{n}^{0}$ 9.795, de 27 de abril de 1999. Dispõe sobre a educação ambiental, institui a Política Nacional de Educação Ambiental. Presidência da República. Disponível em http://www.planalto.gov.br/ccivil_03/leis/19795.htm

. Lei $n^{0} 13.301$, de 27 de junho de 2016. Dispõe sobre a adoção de medidas de vigilância em saúde quando verificada situação de iminente perigo à saúde pública pela presença do mosquito transmissor do vírus da dengue, do vírus chikungunya e do vírus da zika; altera a Lei $\mathrm{n}^{\mathrm{0}}$ 6.437, de 20 de agosto de 1977. Presidência da República. Disponível em http://www.planalto.gov.br/ccivil_03/_Ato20152018/2016/Lei/L13301.htm.

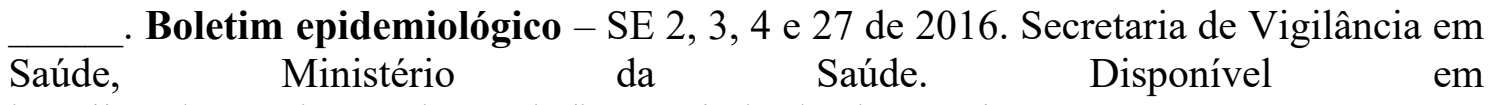
http://combateaedes.saude.gov.br/images/sala-de-situacao/2016-

Dengue_Zika_Chikungunya.

Relatório Conclusivo da Rio92. Senado Federal, agosto, 1992.

Decreto $n^{0} 6.755$, de 29 de janeiro de 2009 . Institui a política nacional de formação de profissionais do magistério da educação básica. Presidência da República. Disponível em http://www.planalto.gov.br/ccivil_03/_ato20072010/2009/decreto/d6755.htm

BRASÍLIA. Decreto $n^{0} 1.188$, de 13 de setembro de 1996. Dispõe sobre a criação do Parque Ecológico e Vivencial do Recanto das Emas. Câmara Legislativa do Distrito Federal.

Cartazes de campanhas oficiais. Secretaria de estado de Saúde do Distrito Federal, 2016. Disponível em http://www.blog.saude.gov.br/combate-aoaedes/50390-combate-ao-mosquito-aedes-e-diagnostico-de-microcefalia.html.

Portaria $\mathrm{n}^{\mathrm{o}} 116$, de 31 de julho de 2012.

BRUNDTLAND, G. Nosso futuro comum. Rio de Janeiro: FGV, 1987.

BURSZTYN, M. e BURSZTYN M.A. Fundamentos de política e gestão ambiental: os caminhos do desenvolvimento sustentável. Rio de Janeiro: Garamond, 2012.

CARR, W. e KEMMIS, S. Becoming Critical: Education, knowledge and action research. Brighton, UK: Falmer Press, 1986.

CARSON, R. Silent Spring. Boston: Houghton Miffin, 1962.

COLMENARES E., A. M. e PIÑERO M., M. L. La investigación acción. Una herramienta metodológica heurística para la comprensión y transformación de realidades y prácticas socio-educativas. Laurus Revista de Educación, v. 14, n. 27, p. 96-114, 2008. Disponível em http://www.redalyc.org/pdf/761/76111892006.pdf 
DESCARTES, R. Discurso do Método. Tradução: Maria Ermantina Galvão. São Paulo: Martins Fontes, 1996.

ELLIOT, J. La Investigación-acción en educación. Morata, España, 2000.

ELLIOT, J. What is action research in schools? Journal of curriculum Studies, v. 10, n. 4, p.335-733, 1978.

FILHO, G. M. Ecodesenvolvimento E Desenvolvimento Sustentável Conceitos E Princípios. Textos de Economia, Florianópolis, v. 4, n. 1, p.131-141, 1993.

FLICKINGER, H. G. O ambiente epistemológico da Educação Ambiental. Revista Educação \& Realidade, v. 19, n. 2, p.197-20, 1994.

FONSECA, I. F., e BURSZTYN, M. Mercadores da moralidade: A retórica ambientalista e a prática do desenvolvimento sustentável. Ambiente \& Sociedade, v. 10, p.171-188. 2007.

GRÜN, M. Ética e educação ambiental: a conexão necessária. Campinas: Papirus, 1996.

FREIRE, P. Pedagogia do oprimido. 50 ed. rev. e atual. Rio de Janeiro: Paz e Terra, 2011.

2014.

Educação como prática da liberdade. $38^{\mathrm{a}}$ ed. São Paulo: Paz e Terra,

. Pedagogia da autonomia: saberes necessários à prática educativa. 43 .

ed., São Paulo: Paz e Terra, 2011.

FRETWELL, H. Environmental education: the science of fear. PercReports, v. 27, n. 3, p.8-11, 2009.

FRIEDBERG, E. O poder e a regra - dinâmicas da ação organizada. Lisboa: Instituto Piaget, 1993.

FRIEDMANN, J. Empowerment: the politics of the alternative development. Cambridge: Blackwell Publishers, 1992.

FURTADO, C. O mito do desenvolvimento Econômico. Rio de Janeiro: Paz e Terra, 1996.

GIL, A. C. Métodos e técnicas de pesquisa social. 5. ed. São Paulo: Atlas, 2007.

GUIMARÃES, M. Educação ambiental crítica. In: LAYRARGUES, P.P. (Org.). Identidades da educação ambiental brasileira. Brasília, DF: Ministério do Meio Ambiente, p. 25-34, 2004. 
GRABAUSKA, C. J. e BASTOS, F. P. Investigação-ação educacional: possibilidade crítica e emancipatórias na prática educativa. Heuresis, Revista Eletrónica de Investigación Curricullar y Educativa, v. 1, n. 2, p. 1-12, 1998. Disponível em http://www2.uca.es/HEURESIS.

HOROCHOVSKI, R. R. Empoderamento: definições e aplicações. $30^{\circ}$ Encontro Anual da ANPOCS, Anais, Eletrônicos GT 18, Caxambu MG, p. 1-19, 2006. Disponível em: http://www.anpocs.org/index.php/2006.

HUNGERFORD, H. R. Environmental Education (EE) for the $21^{\text {st }}$ Century: where have we been? Where are we now? Where are we headed? Journal of Environmental Education, v. 41, p. 1-6, 2010.

IMBERNÓN, F. Formação docente e profissional: formar-se para a mudança e a incerteza. $8^{\mathrm{a}}$ ed. São Paulo: Cortez, 2010.

JOHANSEN, I. C. Urbanização e saúde da população : o caso da dengue em Caraguatatuba (SP). São Paulo, Unicamp, Instituto de Filosofia e Ciências Humanas IFCH, 2014 (Dissertação de Mestrado).

LEFF, E. Epistemologia Ambiental. Tradução de Sandra Valenzuela; revisão técnica: Paulo Freire Vieira. 5. Ed. São Paulo: Cortez, 2010.

LEWIN, K. Action research and minority problems. Journal of Social Issues, v. 2 , p.34-46, 1946.

LEWIN, K.; MACCOBY, E. E.; NEWCOMB, T. M. e HARTLEY, E. L. Group decision and social change. Readings in Social Psychology. Holt, Rinehart and Winston, New York, p.197-211, 1958.

LIMA, G. D. C. O discurso da sustentabilidade e suas implicações para a educação. Ambiente \& Sociedade, v. 6, n. 2, p.99-119, 2003. Disponível em http://doi.org/10.1590/S1414-753X2003000300007.

LITTLE, P. E. Os conflitos socioambientais: um campo de estudo e ação política. In: BURSZTYN, M. (Org.). A difícil sustentabilidade: política energética e conflitos ambientais. Rio de Janeiro: Garamond Universitária, p. 107-122, 2001.

MARCINKOWSKI, T. J. Contemporary Challenges and Opportunities in Environmental Education: Where Are We Headed and What Deserves Our Attention? The Journal of Environmental Education, v. 41, n. 1, p. 34-54, 2010. Disponível em http://doi.org/10.1080/00958960903210015.

McCORMICK, J. Rumo ao paraíso: a história do movimento ambientalista. Rio de Janeiro, Relume-Dumará, 1992.

MEADOWS, D. H; MEADOWS, D. L.; RANDERS, J. e BEHRENS III, WILLIAM, W. Limites do Crescimento. São Paulo: Editora Perspectiva AS, 1973. 
MION, R. A. e BASTOS, F. P. Investigação-ação e a concepção de cidadania ativa. In: Mion, R.A.; Saito, C.H. (Org.). Investigação-Ação: Mudando o Trabalho de Formar Professores. Ponta Grossa-PR: Gráfica Planeta, p. 30 - 35, 2001.

MMA. I CONFERÊNCIA NACIONAL DE EDUCAÇÃO AMBIENTAL. Declaração de Brasília para a Educação Ambiental. Brasília, 1997.

MOLLER, J. Action research with principals: gain, strain and dilemmas. Educational Action Research, v. 6, n. 1, p.69-91, 1998. Disponível em: http://doi.org/10.1080/09650799800200050.

PEDRINI, A. G. e SAITO, C. H. (Orgs.). Paradigmas metodológicos em educação ambiental. Rio de Janeiro, RJ: Vozes, p. 113-131, 2014.

Projeto Político Pedagógico do Centro de Ensino Fundamental 602 do Recanto das Emas, 2015. Arquivo disponível na direção da escola e UNIEB da CRE Recanto das Emas.

RAPPAPORT, J. Empowerment meets narrative: Listening to stories and creating settings. American Journal of Community Psychology, v. 23, n. 5, p.795-807, 1995. Disponível em http://doi.org/10.1007/BF02506992.

ROSA, J. G. Grande Sertão Veredas. Riode Janeiro: Nova Aguilar,1994.

SACHS, I. Desenvolvimento: includente, sustentável, sustentado. Rio de Janeiro: Garamond, 2008.

SACHS, I. Caminhos para o desenvolvimento sustentável. Organização: Paula Yone Stroh. Rio de Janeiro: Garamond, 2009.

SANTOS, C. S. C.; RUIZ, C. J. G.; CARLOS, L. e BLANCO, J. El docente como investigador y transformador de sus propias prácticas . La investigación-acción en educación, v. 9, n. 1, p.14-23, 2013.

SATO, M. Debatendo os desafios da educação ambiental. In: I Congresso de Educação Ambiental Pró Mar de Dentro, Rio Grande: Mestrado em Educação Ambiental, FURG \& pró Mar de Dentro, p.17-21, 2001. Disponível em http://nead.uesc.br/arquivos/Biologia/bsc1/artigo1_Debatendo_os_desafios_da_ed_amb iental.pdf.

SAITO, C. H. Environmental Education and Biodiversity Concern: Beyond the Ecological Literacy. American Journal of Agricultural and Biological Sciences, v. 8, n. 1, p.12-27, 2013. Disponível em http://doi.org/10.3844/ajabssp.2013.12.27

Por que investigação-ação, empowerment e as idéias de Paulo Freire se integram? In: Mion, R.A.; Saito, C.H. (Org.). Investigação-Ação: Mudando o Trabalho de Formar Professores. Ponta Grossa-PR: Gráfica Planeta, p. 126-135, 2001. 
Política Nacional de Educação Ambiental e Construção da Cidadania: revendo os desafios contemporâneos. In: Ruscheinsky, A. (Org.) Educação Ambiental: Abordagens Múltiplas. Porto Alegre: Artmed, p. 54-76, 2012.

SAITO, C.H. (Org) Educação ambiental PROBIO: livro do professor. Brasília: MMA, Departamento de Ecologia da UnB, 136 p., 2006.

SCOTTO, G. Conflitos ambientais no Brasil: natureza para todos ou somente para alguns? Rio de Janeiro: IBASE, 1997.

SEN, A. Desenvolvimento como liberdade. São Paulo: Companhia das Letras, 2010.

SORRENTINO, M.; MENDONÇA, R. T. P. e JUNIOR, L. A. F. Educação ambiental como política pública. Educação e Pesquisa. São Paulo, v. 31, n. 2, p. 285-299, maio/ago. 2005.

STENHOUSE, L. Case study and case records: towards a contemporary history of education. British Educational Research Journal, v. 4, n. 2, p.21-39, 1978.

STORER, T. I; USINGER, R. L.; STEBBINS, R. C.; NYBAKKEN, J. W. 2000. Zoologia Geral. Tradução da 6. Ed. Rev. e aum. norte-americana Erika Schlenz. São Paulo: Companhia Editora Nacional, 2000.

THE CLUB OF ROME. The count-up to 2052: an overarching framework for action. Disponível em: http://www.clubofrome.org/?p=703>

THIOLlENT, M. Metodologia da pesquisa-ação. 2 $2^{\mathrm{a}}$ edição. São Paulo: Cortez, 1986.

TOLEDO, R. F. e JACOBI, P. R. Pesquisa-ação e educação: compartilhando princípios na construção de conhecimentos e no fortalecimento comunitário para o enfrentamento de problemas. Educação \& Sociedade, v. 34, n. 122, p.155-173, jan./mar. 2013.

TOZONI-REIS, M. F. C e VASCONCELLOS, H. S. R. A metodologia de pesquisaação em educação ambiental: reflexões teóricas e relatos de experiência. In. PEDRINI, A. G. e SAITO, C. H. (Orgs.). Paradigmas metodológicos em educação ambiental. Rio de Janeiro: Vozes, p. 113-131, 2014.

TRABUlSI, L. R.; ALTERTHUM, F.; GOMPERTZ, O. F. e CANDEIAS, J. A. N. Microbiologia. $3^{\text {a }}$ ed. São Paulo: Editora Atheneu, 2002.

UNESCO/UNEP. Tbilisi Intergovernmental Conference on Environmental Education, realizado em Tbilisi, Georgia, 1977. Paris (França): UNESCO, 1978. Disponível em: <http://www.gdrc.org/uem/ee/EE-Tbilisi_1977.pdf>.

UNESCO/UNEP. The Belgrade Charter, Adopted by the UNESCO-UNEP International Environmental Workshop, realizado em Belgrado, Outubro de 1975. Belgrado (Servia): UNESCO, $1975 . \quad$ Disponível em: http://unesdoc.unesco.org/images/0001/000177/017772eb.pdf. 
VAZQUEZ, A. S. Filosofia da Práxis. 2a edição. Rio de Janeiro: Editora Paz e Terra, 1977.

VILLAS BOAS, B. Portfólio, avaliação e trabalho pedagógico. São Paulo: Editora Papirus, 2004.

WATTS, B. e JONES, S. Inter-professional practice and action research: commonalties and parallels. Educational Action Research, v. 8, n. 2, p.377-382, 2000. Disponível em http://doi.org/10.1080/09650790000200126. 


\section{ANEXOS}

\section{ANEXO 1}

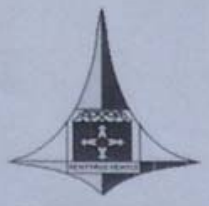

Memorando N2\%2/2016 - EAPE

\section{GOVERNO DO DISTRITO FEDERAL}

SECRETARIA DE ESTADO DE EDUCAÇÃO

Centro de Aperfeiçoamento dos Profissionais de Educação - EAPE

Brasilia, 16 de junho de 2016.

\section{PARA: CRE RECANTO DAS EMAS}

ASSUNTO: Autorização para realizaçăo de pesquisa

\section{Senhor Coordenador,}

Autorizamos LIVIA MIRANDA DE OLIVEIRA, pesquisadora do Curso de Mestrado em Desenvolvimento Sustentável, do Programa de Pós-Graduação em Desenvolvimento Sustentável do Centro de Desenvolvimento Sustentável - CDS UNB - da Universidade de Brasilia, a realizar pesquisa de campo nessa regional.

A pesquisa intitulada "Pesquisa - Açăo em Educaçăo Ambiental Empoderamento Docente para as Práticas Sustentáveis", tem como objetivo analisar de que forma a pesquisa-açăo em educação ambiental, por meio da formaçăo de professores, pode contribuir para o empoderamento docente na busca de práticas educativas sustentáveis.

Dentre as açōes de pesquisas estão incluidas, observaçōes, análise documental, entrevistas e conversaçăo com professores.

A autorizaçăo final da coleta dos dados dependerá do aceite do (a) Gestor (a) da Unidade de Ensino ou setor, objeto da pesquisa.

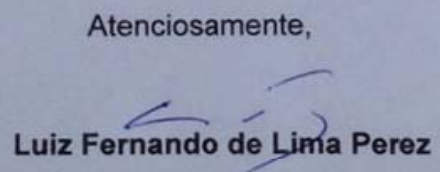

Centro de Aperfeiçoamento dos Profissionais de Educaçāo - EAPE Chefe 


\section{ANEXO 2}

\section{ACEITE INSTITUCIONAL}

O Sr. Marcos Antonio Faria, coordenador regional de ensino da Coordenação Regional de Ensino do Recanto das Emas/Distrito Federal, está de acordo com a realização da pesquisa intitulada "PESQUISA-AÇÃO EM EDUCAÇÃO AMBIENTAL - EMPODERAMENTO DOCENTE PARA PRÁTICAS SUSTENTÁVEIS", de responsabilidade da pesquisadora Livia Miranda de Oliveira, aluna de mestrado no Centro de Desenvolvimento Sustentável - CDS UnB do PPG Desenvolvimento Sustentável da Universidade de Brasilia, realizada sob orientação do Dr. Carlos Hiroo Saito, após revisão e aprovação pelo Comitê de Ética em Pesquisa do Instituto de Ciências Humanas da Universidade de Brasília - CEP/IH.

O estudo envolve a realização de reuniões com grupo de professores, realização de grupos focais, aplicação de questionários, gravação de áudio, registros fotográficos e recolhimento de registros escritos pelos professores atuantes na Secretaria de Estado de Educação do Distrito Federal SEEDF, vinculados à Coordenação Regional de Ensino do Recanto das Emas. A pesquisa terá a duração de oito meses, com previsão de início em outubro de 2015 e término em maio de 2016.

Eu, Marcos Antonio Faria, coordenador regional de ensino da Coordenação Regional de Ensino do Recanto das Emas/Distrito, declaro conhecer e cumprir as Resoluções Éticas Brasileiras, em especial a Resolução CNS 196/96. Esta instituição está ciente de suas co-responsabilidades como instituição co-participante do presente projeto de pesquisa, e de seu compromisso no resguardo da segurança e bem-estar dos sujeitos de pesquisa nela recrutados, dispondo de infraestrutura necessária para a garantia de tal segurança e bem-estar.

Brasilia, 09 de Setembro de 2015.
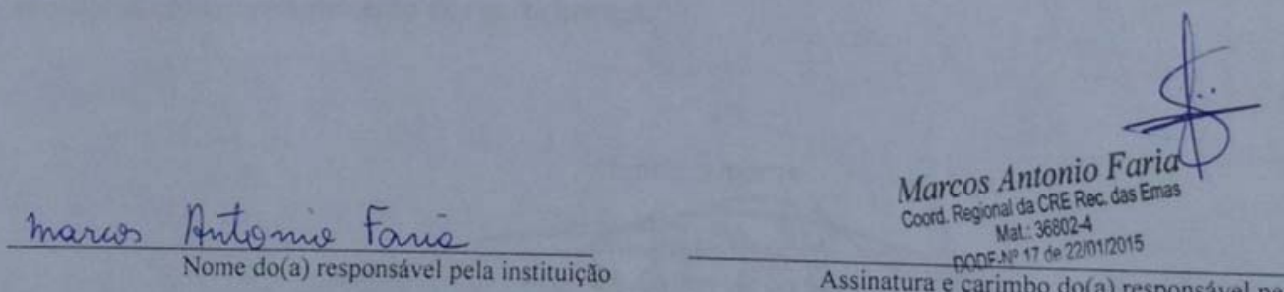

Assinatura e carimbo do(a) responsável pela instituiçào 


\section{ANEXO 3}

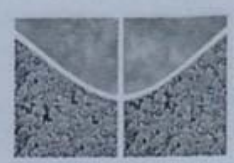

UNIVERSIDADE DE BRASILIA - UnB

CENTRO DE DESENVOLVIMENTO SUSTENTÁVEL - CDS

PROGRAMA DE PÓS-GRADUACÃO FM DESENVOLVIMENTO SUSTENTÁVEL

\section{CARTA DE APRESENTAÇÃO DE PESQUISADOR}

Às

Equipes de Direção e Coordenação Pedagógica do Centro de Ensino Fundamental 602 do Recanto das Emas

Senhores (as),

Eu, Dr. Carlos Hiroo Saito, professor da Universidade de Brasília, apresento a aluna Lívia Miranda de Oliveira como minha orientanda do curso de mestrado, pertencente ao Programa de Pós-Graduação em Desenvolvimento Sustentável do Centro de Desenvolvimento Sustentável da Universidade de Brasília, CDS-UnB.

$O$ projeto de pesquisa desenvolvido pela referida aluna, intitulado "PESQUISA-AÇÃO EM EDUCAÇÃO AMBIENTAL - EMPODERAMENTO DOCENTE PARA PRÁTICAS SUSTENTÁVEIS" tem por objetivo analisar de que forma a pesquisa-ação na EA por meio da formação de professores pode contribuir para o empoderamento docente na busca de práticas que levem os alunos a atitudes mais sustentáveis. O projeto da referida aluna já cumpriu qualificação em dezembro de 2015, e tem apoio formal da Coordenação Regional de Ensino do Recanto das Emas.

No contexto deste projeto, cabe registrar que o professor Alex Sandro Rodrigues Araújo com lotação no CEF 602, participou da primeira etapa do referido projeto e manifestou interesse em dar continuidade aos estudos e contribuir com a pesquisa. Essa participação possibilitará a formação de uma comunidade investigativa, capaz de realizar ações/projetos envolvendo questões ambientais nos espaços de atuação de seus participantes.

A oportunidade de parceria aqui apresentada, além de potencializar o desenvolvimento de atividades/projetos que envolvem as temáticas ambientais (cuja relevância e necessidade de implementação se evidenciam no currículo em movimento da SEDF, no projeto político pedagógico do CEF 602 do Recanto das Emas e nas variadas políticas públicas), tem a intenção e o potencial de promover um ambiente dialógico de aprendizagem coletiva, que resulte em benefícios a toda a comunidade escolar envolvida, promovendo a apropriação de conhecimentos, habilidades e competências, no campo teórico e metodológico de exercício profissional resultando no empoderamento dos participantes.

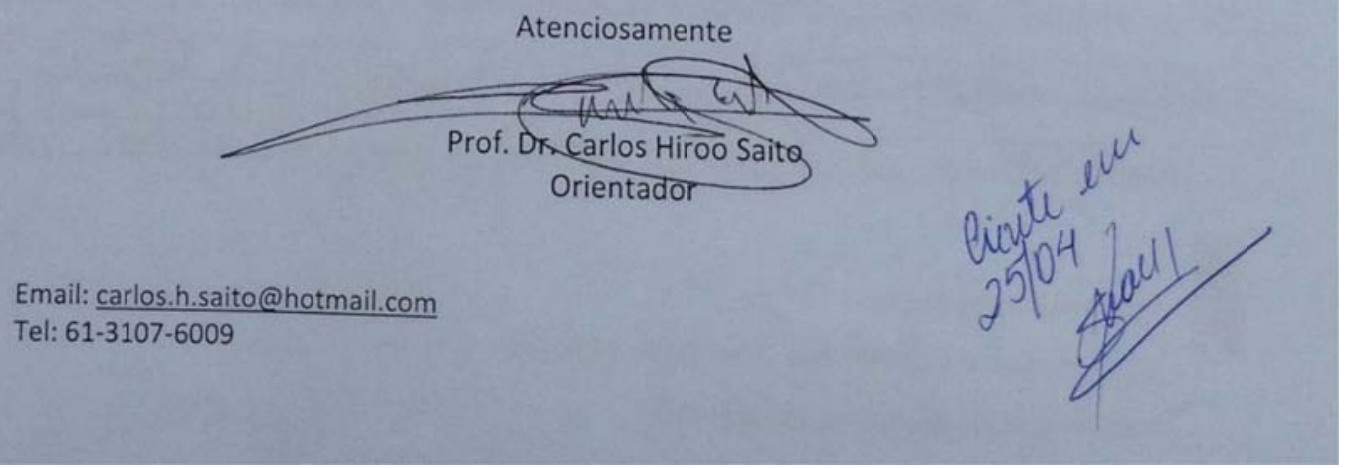




\section{ANEXO 4}

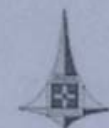

SECRETARIA DE ESTADO DE EDUCAÇÃO DO DISTRITO FEDERAL COORDENAÇÃO REGIONAL DE ENSINO DO RECANTO DAS EMAS CENTRO DE ENSINO FUNDAMENTAL 602

Nome: Turma:

\section{Questionário diagnóstico sobre a dengue}

Objetivo do questionário: Fazer um diagnóstico primário sobre os conhecimentos dos alunos dos oitavos anos do CEF 602 com relação à temática "Dengue, transmissão e combate" que será utilizado como base para os planejamentos das aulas de geografia do segundo bimestre do ano letivo 2016

1. Como a dengue é transmitida.

2. Onde você mora? Alguma pessoa que mora próximo de você já adquiriu dengue? Liste quantas pessoas e se possivel o endereço de onde elas moram.

3. Existe alguma relação entre o ciclo do mosquito e a água?

4. Você considera que os fatores geográficos podem influenciar no aumento de casos da doença? Explique alguns deles e a sua relação com a dengue.

5. De que forma podemos reduzir ou eliminar a doença na nossa cidade?

6. Você já observou se existe algum local na quadra 602 do Recanto das Emas que pode ser um foco para o mosquito Aedes aegypti? Em caso positivo, onde? 
7. Esse ano, algum agente de órgão público fez vistoria em sua casa na busca de focos do mosquito? Quantas vezes?

8. Em sua opinião, as campanhas governamentais tem conseguido combater de forma eficiente a doença? Explique sua resposta.

9. Responda a questão abaixo marcando um " $X$ " em um ou mais itens.

As informações que você adquiriu sobre dengue e o mosquito Aedes aegypti foram adquiridas por meio de:

a( ) Notícias assistidas em telejornais

d( ) Cartilhas educativas. nacionais.

e( ) Na escola por meio de aulas.

b( ) Notícias assistidas em telejornais locais.

$\mathrm{f}($ ) Outras fontes. Quais:

b( ) Notícias da internet.

C( ) Leituras de livros e revistas.

10. Qual a sua opinião sobre a mensagem expressa no cartaz abaixo:

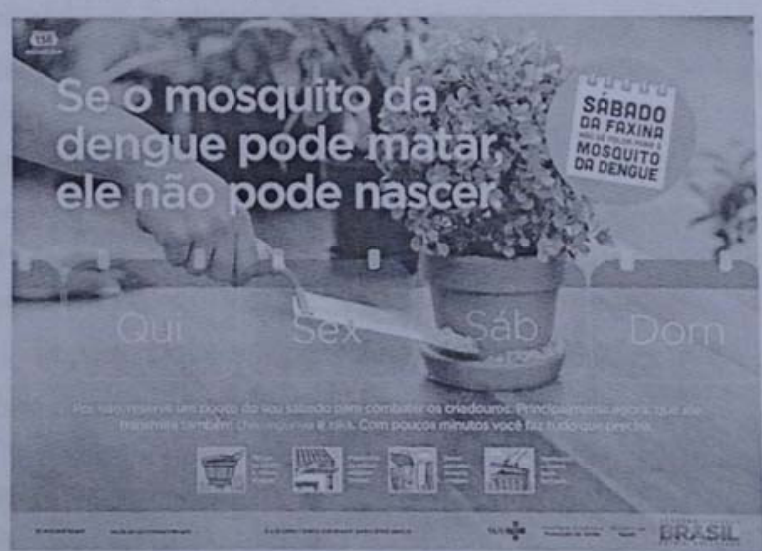

Fonte: $h t t p: / / w w w . b l o g . s a u d e . g o v \cdot b r / c o m b a t e-a o-a e d e s / 50390$-combate-ao-mosquito-aedes-e-diagnostico-de-microcefalia.htm 


\section{ANEXO 5}

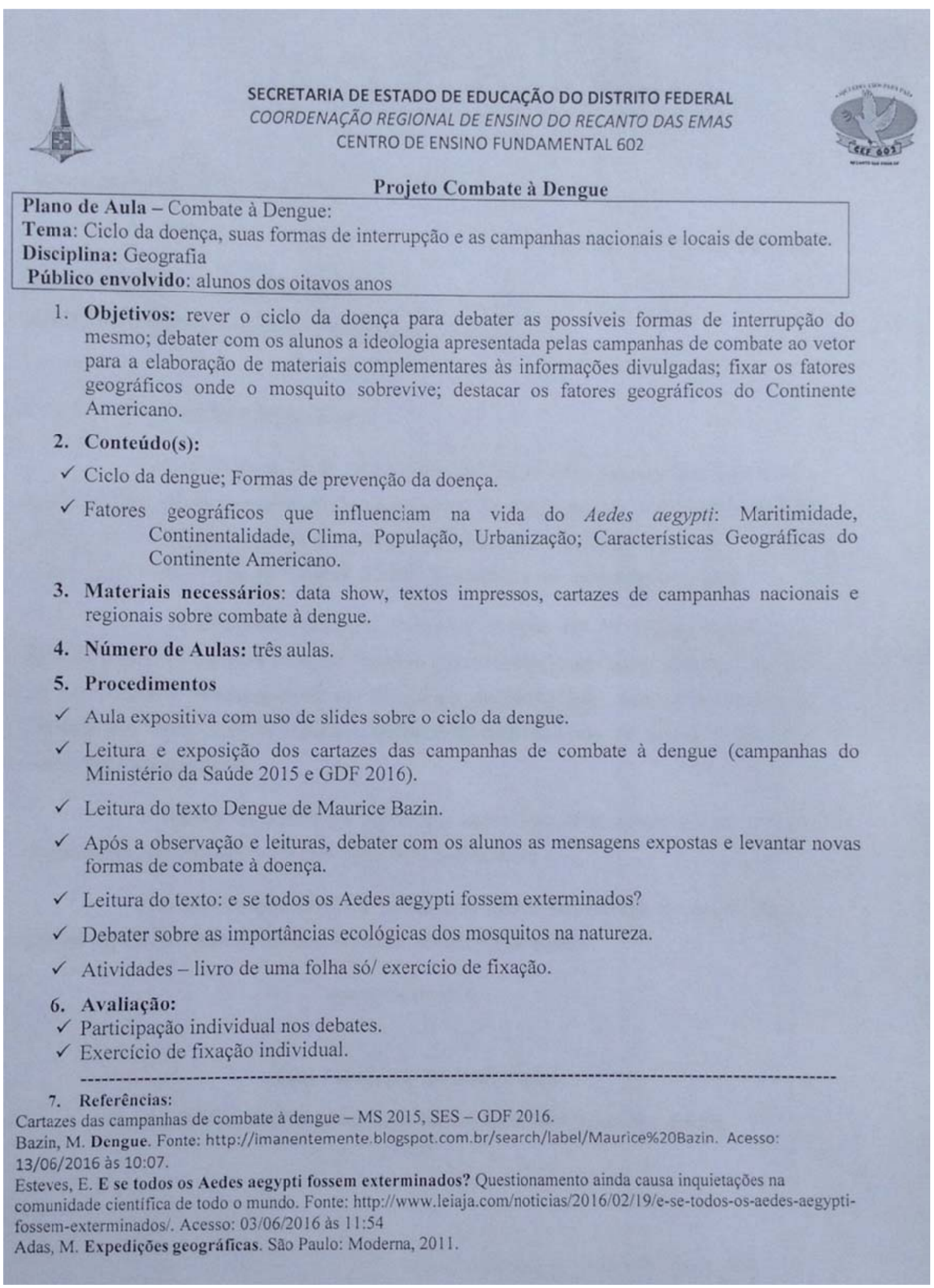


ANEXO 6
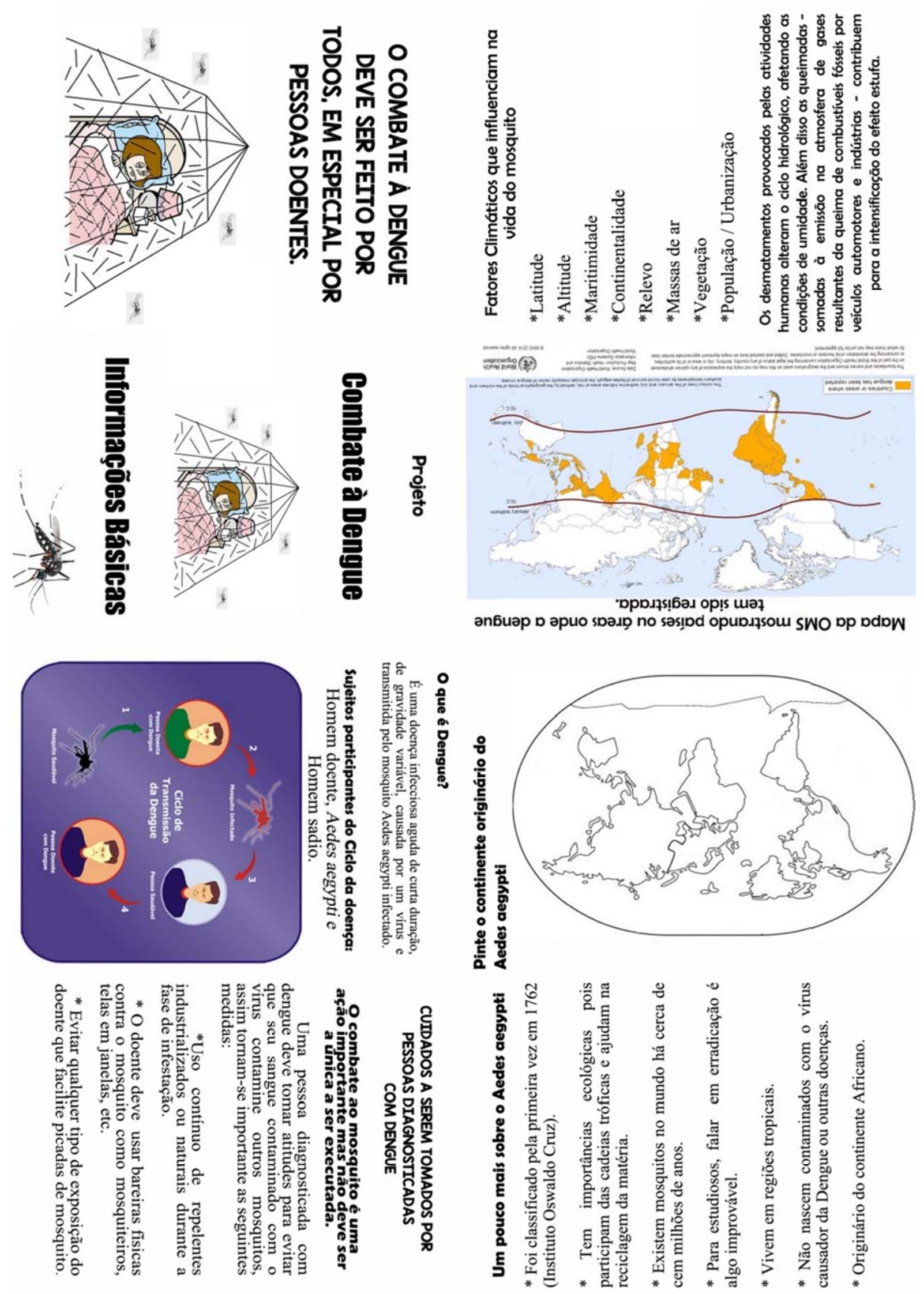

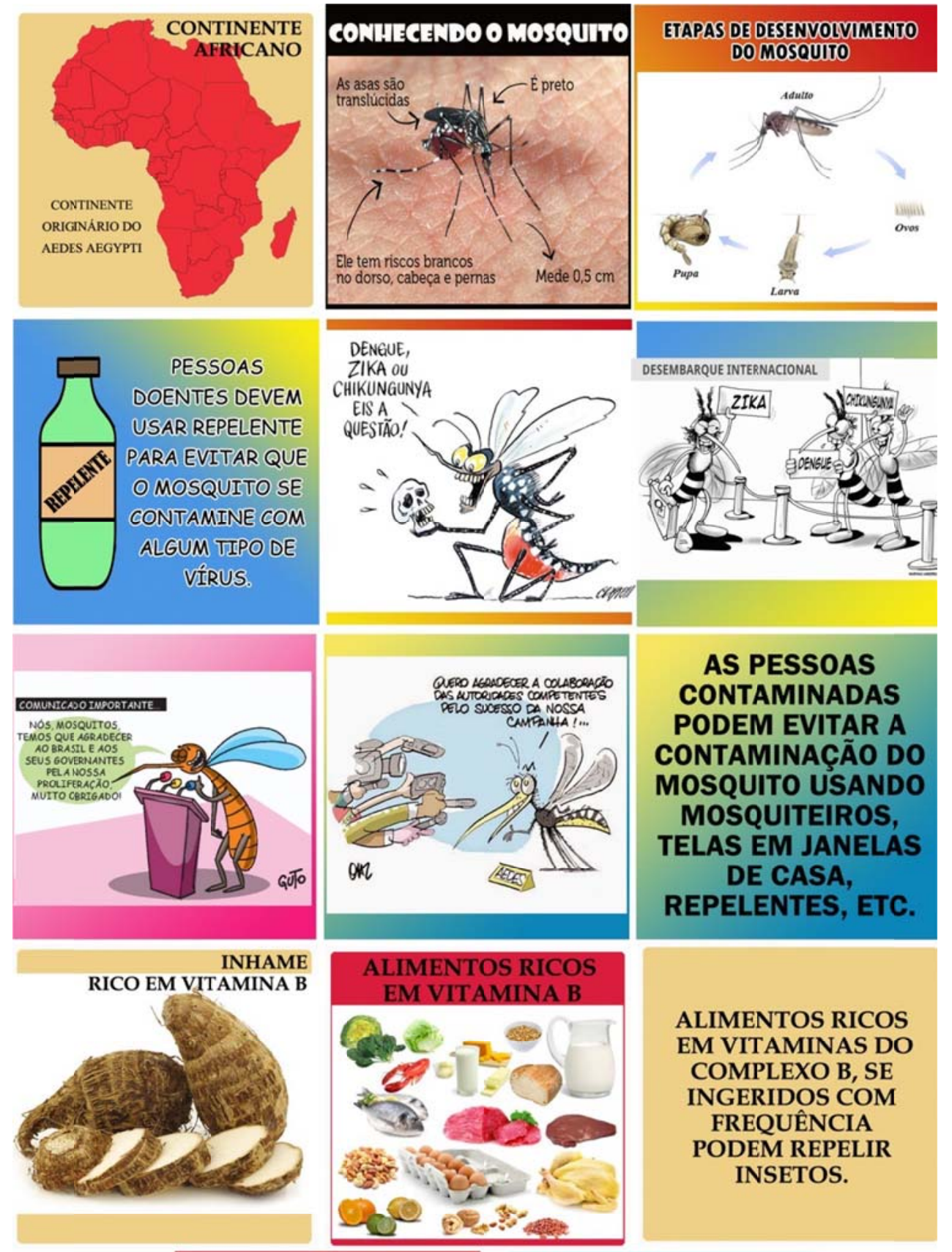
ALIMENTOS RICOS
EM VITAMINAS DO
COMPLEXO B, SE
INGERIDOS COM
FREQUÊNCIA
PODEM REPELIR INSETOS.

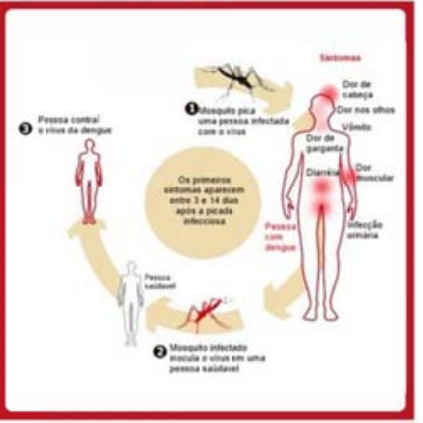

OS COMPONENTES DO

CICLO DA DENGUE SÃO:

HUMANOS

AEDES AEGYPTI

ARBOVÍRUS 
ANEXO 8

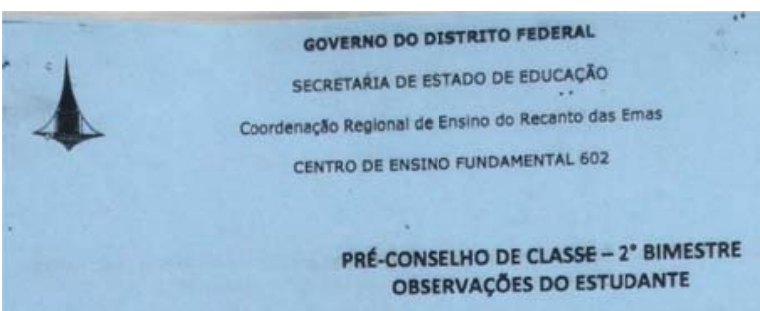

Este instrumento tem o objetivo de contribuir para o aumento da qualidade do ensino em sua escola. Portanto anote suas opiniōes para que se proponham novas açōes para as aprendizagens.

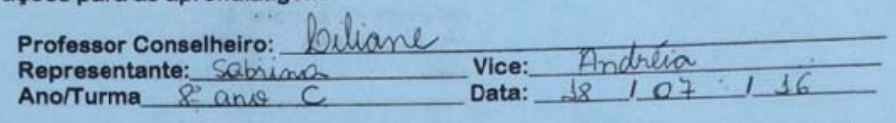

REGISTRO DAS CONSIDERAÇOES: Expresse a opiniāo da TURMA sem julgamentos pessoais, de modo a não ofender nem denegrir a imagem das pessoas envolvidas nesse processo.

1. Como é a sua turma? Como é disciplina e o relacionamento entre vocês?

Positivo: relacionanento intre os colegas

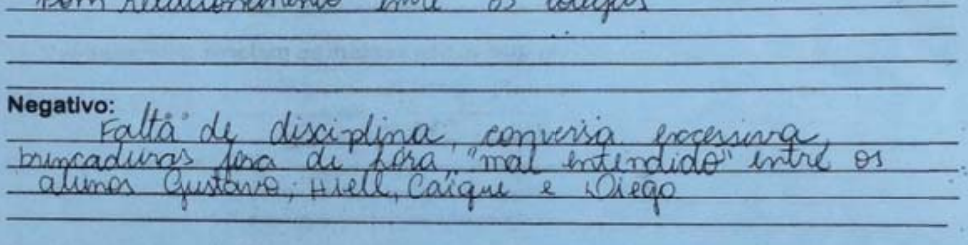

2. O que vocês tem feito para melhorar a limpeza e a conservaçăo das salas de aula e - espaço escolar em geral? Sugestōes:

tim feito musto pouco pulo limpera e conservacát da excela sugestos: Proibir lanches, balas, solopdinnos $\mathrm{cm}$ es patrimonios da excola.

3. Quanto a atuação dos Professores é: ( ) RUIM () REGULAR ( ) BOA (X) OTIMA Há alguma sugestão para auxiliar o trabalho de algum profesor melhorar o aprendizado da turma? levizimar. In mais dominio de turma, paro turma puedu,

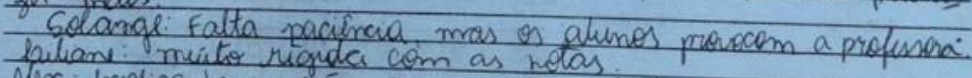

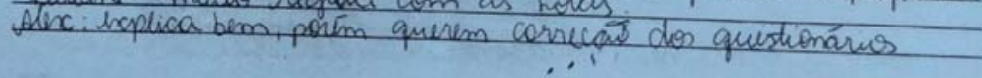

Centro de Ensiso Puadamental 602

Quadra 602 conjunto 01 lote 01 - CEP: 72640-201 Recanto das Fmus - DF

Email: cet602.cretemas 9 gmail com Telefooe: $3901-8248$

7. Você (aluno) tem todo material que necessita? Sabe utilizá-lo em sala de aula ou em

casa? $5 \mathrm{~nm}$. Todos tion materual.

. O que vocês como turma, acreditam que pode melhorar na sua escola?

iving as cadivias no muro qui pode dugk dengue.

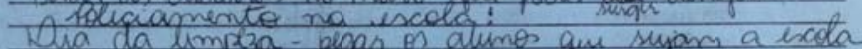
para des limparem no sábado

Assinatura dos Presentes:

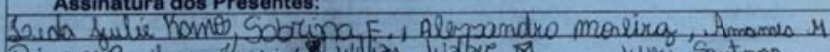

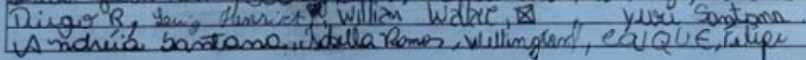

Ceatro de Encino Pudameatal 602

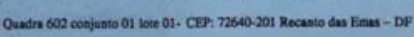

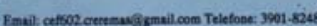


ANEXO 9

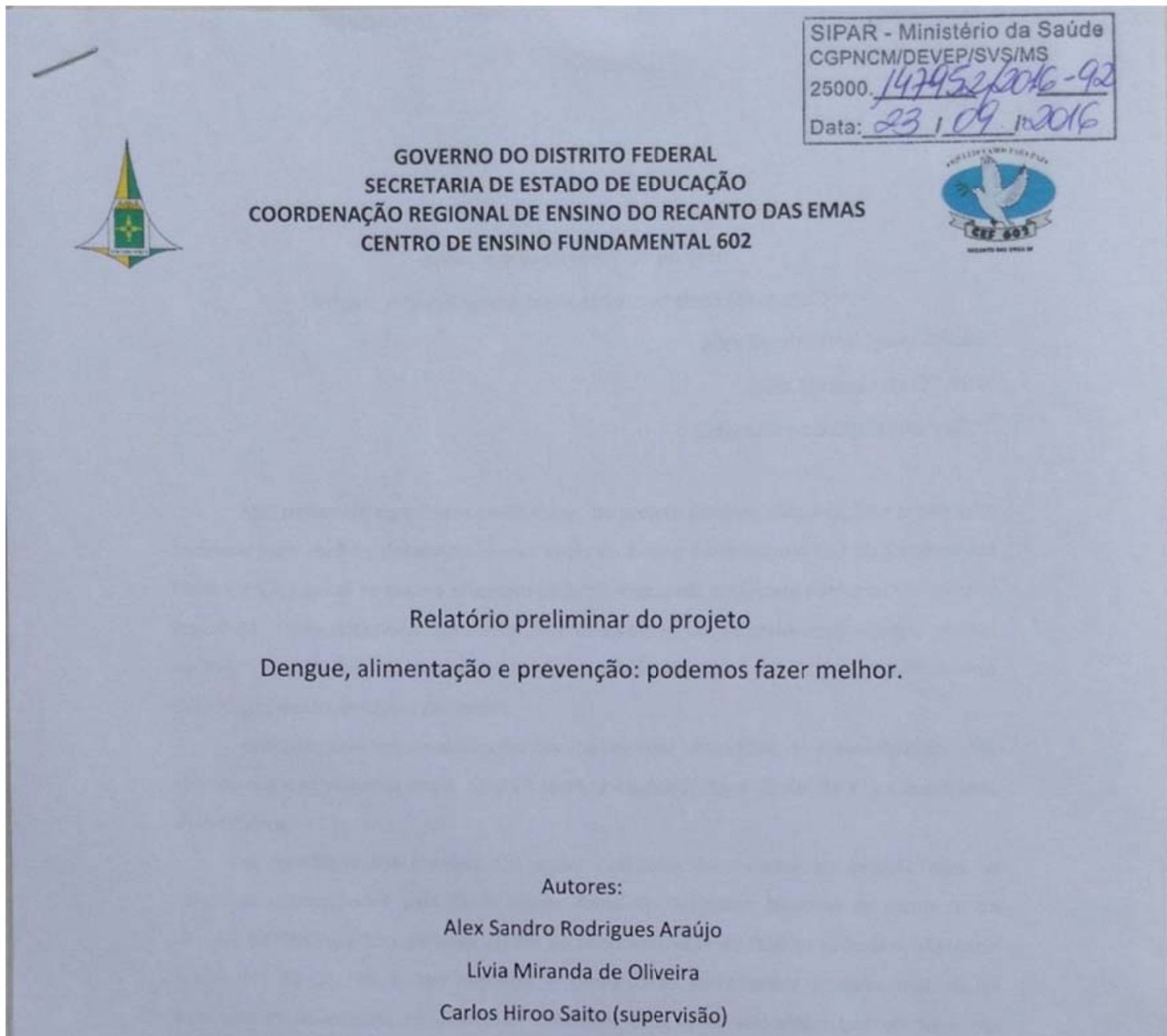

Brasília, setembro 2016 


\section{ANEXO 10}

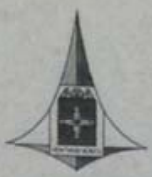

GOVERNO DO DISTRITO FEDERAL SECRETARIA DE ESTADO DE EDUCAÇÃO COORDENAÇÃO REGIONAL DE ENSINO DO RECANTO DAS EMAS CENTRO DE ENSINO FUNDAMENTAL 602

\section{Relatório preliminar do projeto}

Dengue, alimentação e prevenção: podemos fazer melhor.

Autores:

Alex Sandro Rodrigues Araújo

Lívia Miranda de Oliveira

Carlos Hiroo Saito (supervisão)

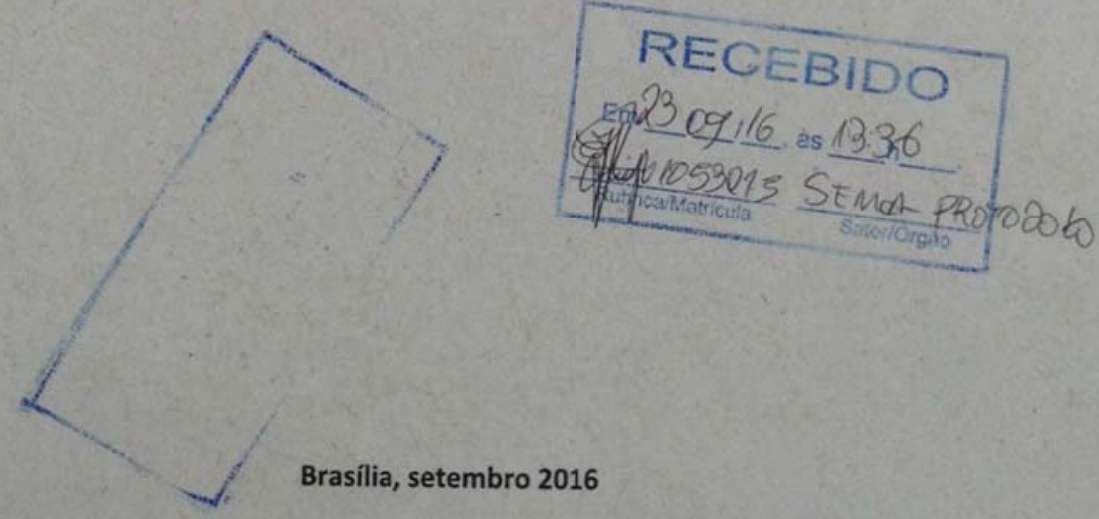




\section{ANEXO 11}

Termo de Autorização para Utilização de Imagem, Som de Voz e registro escrito

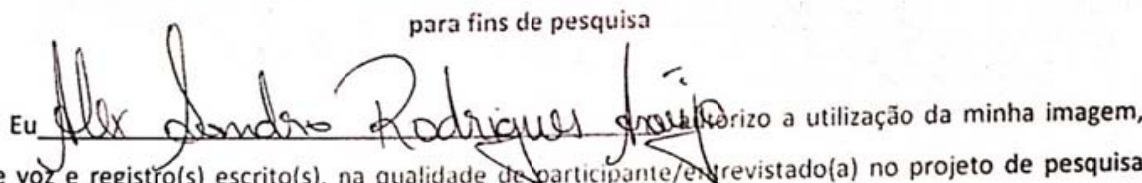
som de voz e registro(s) escrito(s), na qualidade de barticipante/entrevistado(a) no projeto de pesquisa intitulado "PESQUISA-AÇĀO EM EDUCAÇÃO AMBIENTAL - EMPODERAMENTO DOCENTE PARA PRÁTICAS SUSTENTÁVEIS", Sob responsabilidade de Livia Miranda de Oliveira, vinculado ao Programa de PósGraduação em Desenvolvimento Sustentável do Centro de Desenvolvimento Sustentável - CDS da Universidade de Brasilia.

Minha imagem, som de voz e registro(s) escrito(s) podem ser utilizados apenas para análise de dados relevantes ao possivel cumprimento dos objetivos da pesquisa, publicações acadêmicas que se fizerem necessárias, apresentações em conferências profissionais e/ou acadêmicas e realização de atividades educacionais

Tenho ciência de que não haverá divulgação da minha imagem, som de voz ou registro(s) escrito(s) por qualquer meio de comunicação, sejam elas televisão, rádio ou internet, exceto nas atividades vinculadas ao ensino e a pesquisa explicitadas acima. Tenho ciència também de que a guarda e demais procedimentos de segurança com relaçäo às imagens e sons de voz são de responsabilidade do(a) pesquisador(a) responsável.

Deste modo, declaro que autorizo, livre e espontaneamente, o uso para fins de pesquisa, nos termos acima descritos, da minha imagem, som de voz e registro(s) escrito(s).

Este documento foi elaborado em duas vias, uma ficará com o(a) pesquisador(a) responsável pela pesquisa e a outra com o(a) participante
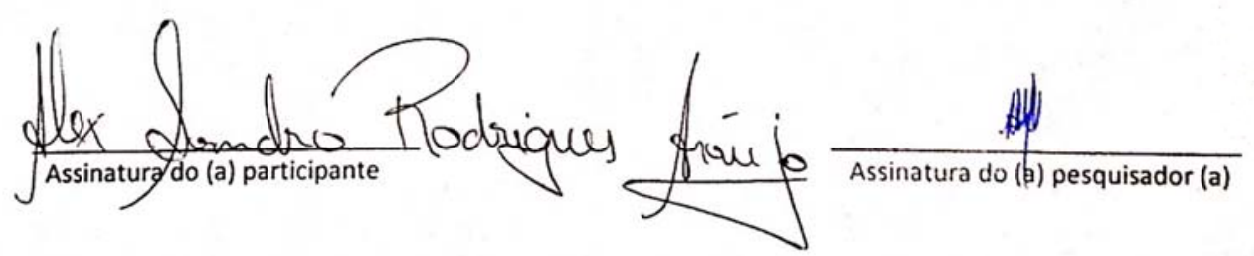

Brasilia, 03 de marce de 2016 